\title{
Late Viséan-early Serpukhovian cyanobacteria and algae from the Montagne Noire (France); taxonomy and biostratigraphy
}

\author{
DANiel VACHARD, Pedro Cózar, MARKus ARetZ \& Alain IZART
}

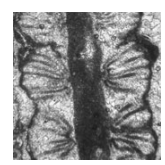

\begin{abstract}
A revision of the late Mississippian (late Viséan-early Serpukhovian) cyanobacterial and algal assemblages of Montagne Noire (Aude-Hérault, France) is undertaken, mainly based on new data recently obtained with the foraminiferal assemblages of this area. In this taxonomic contribution, one tribe Borlatellae trib. nov. is translated, and three new genera Ortonellopsis gen. nov., Anchisolenopora gen. nov. and Neoradiosphaeroporella gen. nov., and four new species of algae are described: Ortonellopsis laxa gen. et sp. nov., Anatolipora macroporelloidea sp. nov., Paraepimastopora somervillei sp. nov., and Neoradiosphaeroporella aprica gen. et sp. nov. In the Algospongia (incertae sedis algae), the genera Zidella, Valuzieria emend. herein and Asteroaoujgalia are revised. Most of the species appear to be restricted to the latest Viséan-early Serpukhovian interval in the Montagne Noire, and thus, they have to be investigated in coeval Tethyan and Uralian areas for their possible biostratigraphic importance. - Key words: algae, Viséan, Serpukhovian, Montagne Noire, southern France, systematics, biostratigraphy.
\end{abstract}

VACHARD, D., CÓZAR, P., ARETZ, M. \& IZART, A. 2016. Late Viséan-early Serpukhovian cyanobacteria and algae from the Montagne Noire (France); taxonomy and biostratigraphy. Bulletin of Geosciences 91(3), 433-466 (13 figures). Czech Geological Survey, Prague. ISSN 1214-1119. Manuscript received April 13, 2016; accepted in revised form June 16, 2016; published online August 9, 2016; issued November 25, 2016.

Daniel Vachard (corresponding author), 1 rue des Tilleuls, 59152 Gruson, France; Daniel.Vachard@free.fr •Pedro Cózar, Instituto de Geociencias CSIC-UCM, 28040 Madrid, Spain - Markus Aretz, Géosciences Environnement Toulouse (GET), Observatoire Midi-Pyrénées, Université de Toulouse, CNRS, IRD, UPS, 14 avenue E. Belin, 31400 Toulouse, France • Alain Izart, 202 Chemin de Cabanis, 34730 Prades-le-Lez, France

On the southern slope of the Montagne Noire (southern France), the lithologic unit called "calcaires à Productus" is composed of small to large carbonate lenses embedded within a very thick lower Carboniferous siliciclastic complex (Fig. 1A) which are generally interpreted as olistoliths and flysch, respectively. Several authors demonstrated that these successions are late Viséan to early Serpukhovian in age (Böhm 1935; Gèze 1949; Mamet 1968; Vachard 1974a, b, 1977a, b; Engel et al. 1982; Feist \& Galtier 1985; Poty et al. 2002; Aretz 2002, 2016; Vachard \& Aretz 2004; Korn \& Feist 2007; Pille 2008; Vachard et al. in press). The eight foraminiferal regional biozones of Vachard et al. (in press) significantly refine the stratigraphic frame for the Viséan-Serpukhovian boundary interval in the Montagne Noire. Because of problems with the classical biozonations and substages in northern England, as well as in northern France and Belgium, Vachard et al. (in press) mainly compared the biozones of the Montagne Noire with the Russian standard substages (Fig. 1B). Hence, biozones A and B are correlated with the Mikhailovian (that would be correlated with the latest Asbian and earliest Brigantian in western
Europe); the biozones C, D and E are correlated with the Venevian (equivalent to the upper part of the early Brigantian in western Europe), and the biozones F, G and $\mathrm{H}$ are correlated with the Tarusian (lower part of the late Brigantian in northern England). Foraminiferal markers of the Steshevian (late early Serpukhovian) might be present in the foraminiferal assemblages of the biozones $\mathrm{G}$ and $\mathrm{H}$. The aims of this paper are: 1) to describe new cyanobacterial and algal taxa from the Montagne Noire; 2) to include the distribution of the cyanobacteria, algae and algospongia in the new biostratigraphic scheme of Vachard et al. (in press); and 3) to characterize some additional stratigraphic biomarkers, distinct of the foraminifers, of the Viséan-Serpukhovian boundary interval.

\section{Cyanobacterial and algal assemblages}

In total, more than 5000 thin sections have been studied from numerous stratigraphic sections. These thin sections belong to three collections of the authors, D. Vachard's 
(labelled as DV-), M. Aretz' (labelled as MA-), and P. Cózar's (labelled as Pc-) collections.

The late Viséan-early Serpukhovian cyanobacteria assemblages are essentially composed of: 1) chabakoviaceans with uniseriate and ramified series of hemispherical to reniform trichomes, entirely or partially mineralized in dark or grayish microgranular calcite (Renalcis Vologdin, 1932; Fig. 2A); 2) aphralysiaceans with short, arched trichomes and dark-microgranular or white and microsparitic walls (Aphralysia Garwood, 1914, Sparaphralysia Vachard in Vachard \& Beckary, 1991; Fig. 2B-E); 3) girvanellaceans with cylindrical trichomes with rare or absent pseudo-ramifications, and a dark-microgranular wall (Girvanella Nicholson \& Etheridge, 1878, Mitcheldeania (Wethered, 1886) Mamet \& Roux, 1975b; Fig. 2F); 4) garwoodiaceans with frequent ramifications (Ortonella Garwood, 1914, Ortonellopsis gen. nov., Garwoodia Wood, 1941; Figs 2G, $3 \mathrm{~A}-\mathrm{G})$; in addition to this skeletal cyanobacteria, various biocalcifications generally assigned to this phylum were found, in the form of microbialites (sensu Brune \& Moore 1987 and Riding 1991; = spongiostromids, clotted textures, loferites, or thrombolites auctorum), ?Bacinella Radoicic, 1959, Nostocites Maslov, 1929 and Baccanella Pantic, 1971 (= Palaeomicrocodium Mamet \& Roux, 1983).

Red algae mainly comprise: 1) elianellaceans (Anchisolenopora gen. nov.; Figs 2H, 4A), 2) archaeolithophyllaceans (Neoprincipia Cózar \& Vachard, 2003 and Archaeolithophyllum Johnson, 1956) (Fig. 4B-I); and 3) incerti ordinis (Hortonella Mamet, 1995 ex Cózar \& Vachard, 2005; Fig. 4E).

Green algae mainly comprise: 1) questionable bryopsidales and 2) dasycladales. The former are composed of: a) udoteaceans? (Mellporella? aff. "magnum" (sensu Lemosquet \& Poncet 1977 non Endo 1951); Fig. 5A-D), and b) incerti ordinis (Orthriosiphon Johnson \& Konishi, 1956 and Saccamminopsis Sollas, 1921; Fig. 7B, C).

The dasycladales are represented by some epimastoporaceans (Paraepimastopora Roux, 1979 emend. Krainer \& Vachard, 2002, Palaepimastoporella Cózar \& Vachard, 2004; Fig. 7D-I), and variegated diploporaceans (see Pille 2008 and Pille \& Vachard 2011). They are represented by traditional taxa like Kulikia Golubtsov, 1961, Windsoporella Mamet \& Rudloff, 1972 ex Vachard, 1980, Eovelebitella Vachard, 1974a, Cabrieropora Mamet \& Roux, 1975a, Guadiatella Cózar et al., 2007, Coelosporella Wood, 1940 and Nanopora Wood, 1964 (Fig. 8A-K), and by recently described members of the tribe Borladellineae: Cabrieroporellopsis Pille \& Vachard, 2011, Murvielipora Pille \& Vachard, 2011, and Borladella Cózar et al., 2007 (Fig. 8L-O). Questionable polyphysaceans are represented by Neoradiosphaeroporella gen. nov. (Fig. 9A-G); and questionable dasycladales, by Koninckopora Lee, 1912 the latter being rare in the Montagne Noire.
Ulotrichales (or questionable dasycladales) are relatively common Anatolipora Konishi, 1956 emend. herein: A. carbonica Konishi, 1956 emend. herein and A. macroporelloidea sp. nov. (Fig. 6A-I), and scarce Richella Mamet \& Roux in Mamet et al., 1987 (Fig. 7A).

The algae incertae sedis of the fossil class Algospongia are represented by (1) diversified moravamminales: issinellaceans (Issinella Reitlinger, 1954; Zidella Saltovskaya, 1984; Fig. 10A, B), anthracoporellopsidaceans (Crassikamaena Brenckle, 1985 = ?Evlania Bykova, 1952, see Falahatgar et al. 2015; Fig. 10C); kamaenaceans (Kamaena Antropov, 1967, Kamaenella Mamet \& Roux, 1974; Figs 10O, 11F, G?, H?); palaeoberesellaceans (Exvotarisella Elliott, 1970, Palaeoberesella Mamet \& Roux, 1974; Fig. 10D, R); claracrustaceans (Asphaltinella Mamet \& Roux, 1978, Claracrusta Vachard, 1980, Praedonezella Kulik, 1973 ex Vachard \& Cózar, 2010; Figs 10G, H, 12C); (2) aoujgaliales: aoujgaliaceans (Sinustacheoides Termier et al., 1977, Stacheoides Cummings, 1955b, Costacheoides Vachard \& Cózar, 2010, Aoujgalia Termier \& Termier, 1950, Asteroaoujgalia Brenckle, 2004, Epistacheoides Petryk \& Mamet, 1972, and Roquesselsia Termier et al., 1977; Figs 10E, F, I-N, P, Q, S), ungdarellaceans (Ungdarella Maslov, 1950; Fig. 12A), stacheiaceans (Stacheia Brady, 1876, Fourstonella Cummings, 1955a ex Vachard \& Cózar, 2010; Fig. 11A-D), and (3) calcifoliales (Fasciella Ivanova, 1973, Fascifolium Vachard, Karim \& Cózar in Vachard \& Cózar, 2010, Frustulata Saltovskaya, 1984, Falsocalcifolium Vachard \& Cózar, 2005 and very rare Calcifolium Shvetsov \& Birina, 1935; Figs 11E, 12B-J).

\section{Systematic palaeontology}

Phylum Cyanobacteria (Stanier, 1974) ex Cavalier-Smith, 2002

Class Cyanophyceae Schaffner, 1909

Incerti ordinis

Family Garwoodiaceae Shuysky, 1973

Description. - Nodular to elongate colonies of cylindrical trichomes with frequent ramifications with various angle and types of bifurcation. Sheath calcitic, dark-microgranular.

Remark. - Prior to the hierarchical translation of Shuysky (1973), sometimes attributed to Johnson (1964) (see Emberger 1976), the group was first named as a tribe by Endo (1961a, p. 24).

Occurrence. - Cambrian-Permian, cosmopolitan (e.g., Mamet 1991). Modern equivalents seem to be known 


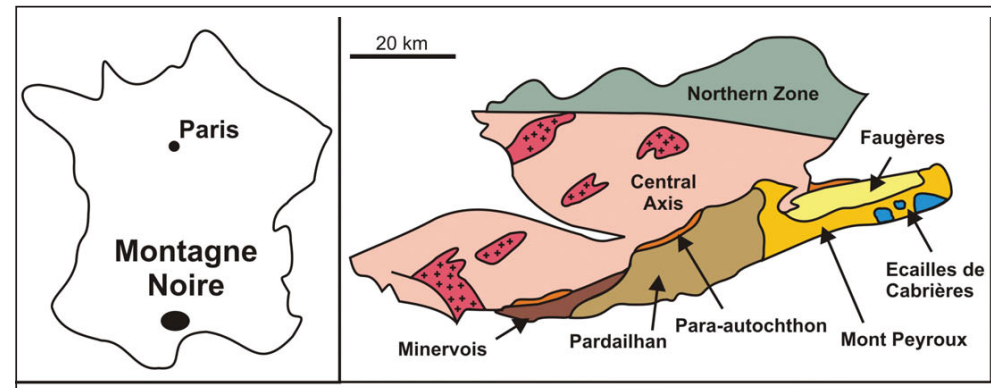

A

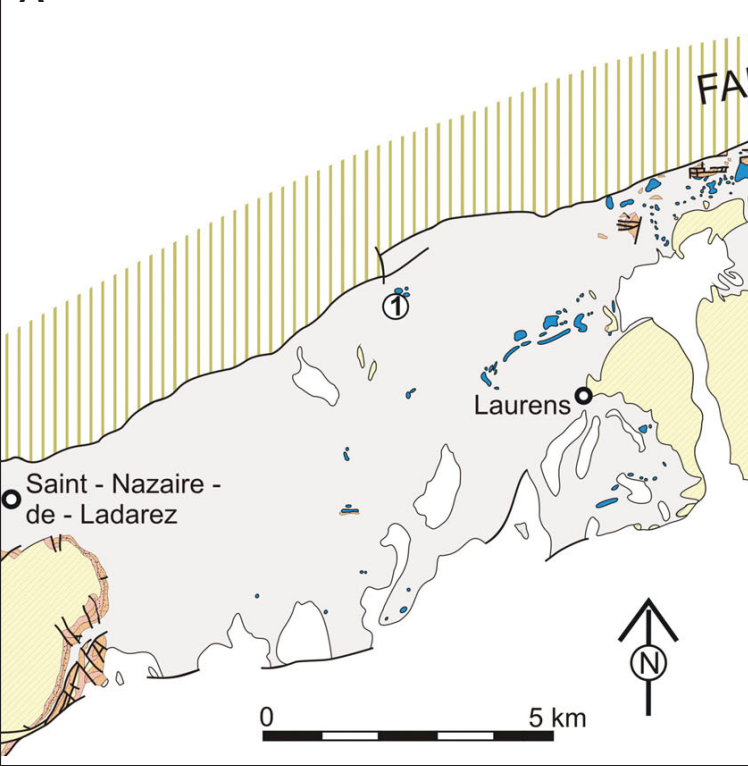

Figure 1. A - location of the studied sections and outcrops in the Montagne Noire. 1. La Boutinelle, 2. Castelsec, 3. Roc du Cayla, 4. Les Pascales, 5. Roc de Murviel, 6. Roquemaillère, 7. Château-Vailhan, 8. Les Mentaresses, 9. Roque Redonde, 10. La Serre, 11. Japhet, 12. La Serre de Péret. Modified from Aretz (2016) and Vachard et al. (in press). • B - correlation of the biozones in the Montagne Noire defined by Vachard et al. (in press) with other zonal schemes and biozones from Europe. Column 1. Standard Russian substages. 2. Biozones of the Montagne Noire. 3. Correlation of the Western European substages in the shallow water facies of Pennines (northern England) (according to Cózar \& Somerville 2014, 2015). 4. Foraminiferal biozones defined by Conil et al. (1980). 5. Traditional biozones in Belgium. 6. Foraminiferal biozones of Poty et al. (2006).

(e.g., Riding 1975); therefore, this morphogenus persisted over all fossiliferous times.

\section{Genus Ortonellopsis Vachard \& Cózar gen. nov.}

Type species. - Ortonellopsis laxa Vachard \& Cózar gen. et sp. nov.

Etymology. - Comparable with Ortonella (because of the bifurcation of filaments) and ending opsis, almost.

Diagnosis. - Colonies constituted of loosely packed filaments bifurcating with an acute angle.

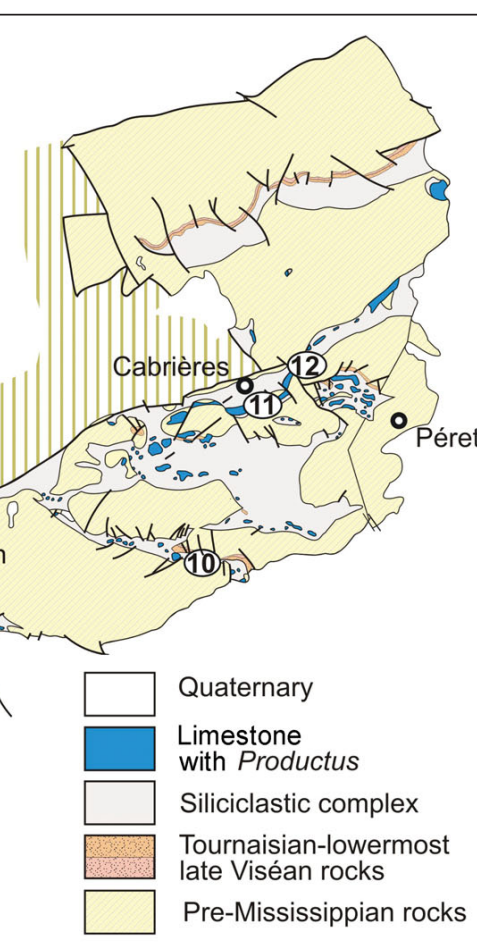

B

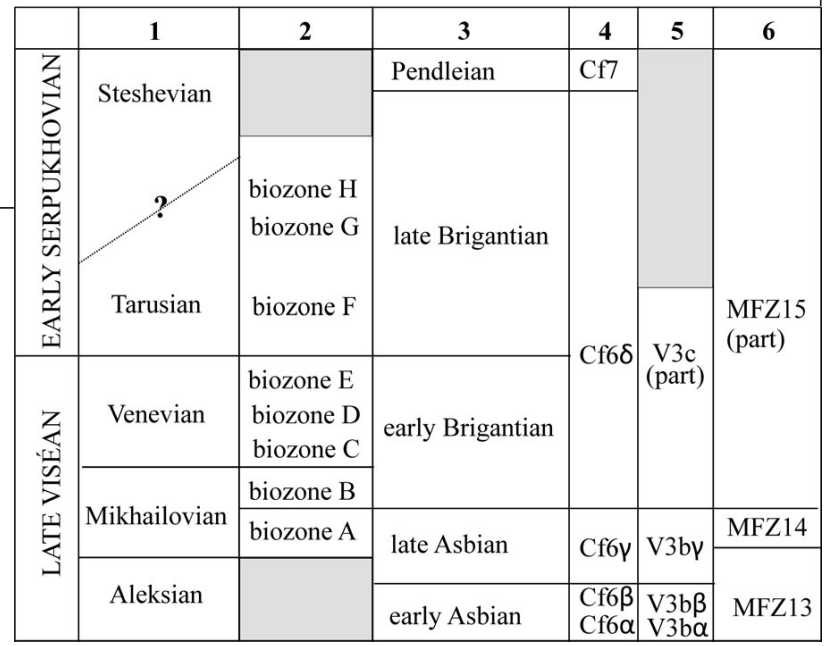

Composition. - Ortonellopsis laxa sp. nov.; Ortonella mansellensis Poncet, 1986; Ortonella myrae Rácz, 1964.

Comparison. - Ortonellopsis differs from Ortonella in the loose filaments, whereas the angles of bifurcation are similar, from Gaspesiella Mamet \& Roux in Bourque et al., 1981 in the type of bifurcation, from Paramitcheldeania Mamet, 2002 in the constant diameter of the trichomes. Bevocastria magna Senowbari-Daryan \& Link, 2004 has some similarities with Ortonellopsis, but differs by its pseudo-septation (conspicuous for instance in the fig. $3 \mathrm{~d}$, f-h of Senowbari-Daryan \& Link 2004, even if this diagnostic criterion is not mentioned by these authors). Because of this pseudo-septation, Bevocastria magna belongs 
in reality to the Cretaceous genus Maurinella Granier et al., 1991. Due to the absence of pseudo-septation and despite the similarities of some groups of trichomes (see Granier 2015, fig. 25), Ortonellopsis gen. nov. differs from Maurinella.

Occurrence. - Silurian-Triassic of Canada (Poncet 1986), southern France (this work), Spain (Rácz 1964), Carnic Alps (Flügel \& Flügel-Kahler 1980), and Greece (Schäfer \& Senowbari-Daryan 1983).

\section{Ortonellopsis laxa Vachard \& Cózar gen. et sp. nov.} Figure 3A-G

v. 1974b Ortonella furcata Garwood. - Vachard, p. 175, pl. 6, fig. 5 , pl. 7 , fig. 5 .

v. 1977a Ortonella furcata Garwood. - Vachard, p. 374, table 1 (no illustration).

v. 1977a Ortonella aff. furcata Garwood. - Vachard, p. 374, table 1.

v. 1977b Ortonella furcata Garwood. - Vachard, p. 136, pl. 1, fig. 2.

v.p. 2008 Ortonella spp. - Pille, pl. 5, figs 1, 2 (non pl. 4, figs 1-7 = true Ortonella).

v. 2008 Ortonellopsis laxa Pille, p. 24, pl. 5, figs 3-10 (nomen nudum).

Etymology. - Latine laxus, loose, because the filaments are loosely spaced.

Locus typicus. - Roc de Murviel.

Stratum typicum. - Tarusian (earliest Serpukhovian).

Diagnosis. - Elongate colonies formed of trichomes bifurcated as in Ortonella, but not joined together. The walls of the trichomes are dark-microgranular, whereas the spaces between the trichomes are cemented by a microsparitic calcite.

Holotype. - MA-RM83 (Fig. 3D); Aretz' collection, Toulouse.

Description - Outer diameter $=0.032 \mathrm{~mm}$; angle of bifurcation $=40^{\circ}$.

Type material. - 25 well-preserved colonies (a base of colony was even observed in the thin section DV227C).

Comparison. - Ortonellopsis laxa is homeomorphous of Ortonella furcata and Maurinella sp. sensu Granier (2015), although it differs in the genus characters: i.e., from Ortonella by microsparitization of the open spaces between the trichomes, and from Maurinella by the absence of pseudo-septation.

Remarks. - It is currently difficult to explain the very rapid microsparitic calcification between the trichomes independently calcified in micrite.

Occurrence. - Venevian-Steshevian (latest Viséan-early Serpukhovian $=$ foraminiferal biozones $\mathrm{C}$ to $\mathrm{G})$. La Serre-vineyard (DV165A, DV165B, DV165E, DV227B, DV227C, MA-LSV-2004), La Boutinelle (MA-Bou25-13, MA-Bou25-15), Les Pascales (Pc-4618, Pc4619), Roc du Cayla (Pc4576, Pc4597), Château-Vailhan (Pc4734), Roc de Murviel (MA-330-6, MA-33-6, MA-33-86, MA-33-78, MA-33-76, MA-33-73, MA-33-55, MA-33-54, MA-RM-9, MA-RM-20, MA-RM-21, MA-RM-29, MA-RM-35, MA-RM83, Pc-4503, Pc-4506, Pc-4513, Pc-4462, Pc-4472, Pc-4473, Pc-4908), and Roque Redonde (Pc-4407, Pc-4401，Pc-4399，Pc-4397，MA-RR-81，MA-RR-82, MA-RR-83).

Phylum Rhodophycophyta Papenfuss, 1946

Family Elianellaceae Granier in Granier \& Dias-Brito, 2016 (= Solenoporaceae Pia, 1927 auctorum)

Remarks. - The validity and botanical assignment of the family Elianellaceae (formerly "Solenoporaceae") as a homogeneous taxonomical group have been often questioned (Woelkerling 1988; Brooke \& Riding 1998, 2000; Aguirre \& Barattolo 2001; Riding 2004; Cózar \& Vachard 2006; Granier \& Dias-Brito 2016). To partially replace the name Solenoporaceae, Brooke \& Riding (1998, 2000) introduced the new family Graticulaceae and compared it to the extant family Sporolithaceae of the order Corallinales (Silva \& Johansen 1996). Woerkerling (1988) and Aguirre \& Barattolo (2001) considered the "Solenoporaceae" as incertae sedis algae. Riding (2004) interpreted the type species Solenopora spongioides Dybowski, 1878 as a chaetetid sponge, and assigned the classical Solenoporaceae Parachaetetes Deninger, 1906 and Pseudochaetetes Haug, 1883 also to chaetetids. In contrast, Riding (2004) considered Marinella Pfender, 1939, Metasolenopora Yabe, 1912, Petrophyton Yabe, 1912 and Solenoporella Rothpletz, 1908 as red algae, even though he did not give a new family name for these former algal solenoporaceans. The name Elianellaceae was proposed by Granier in Granier \& Dias-Brito (2016). We accept this name in order to resolve this old taxonomical problem, even if the first genus name mentioned as synonym for an algal Solenopora has been Metasolenopora Yabe, 1912 (see e.g., Pia 1927, Peterhans 1929, Poignant 1991), and if the derived family name Metasolenoporaceae would be more reminiscent of Solenoporaceae. 

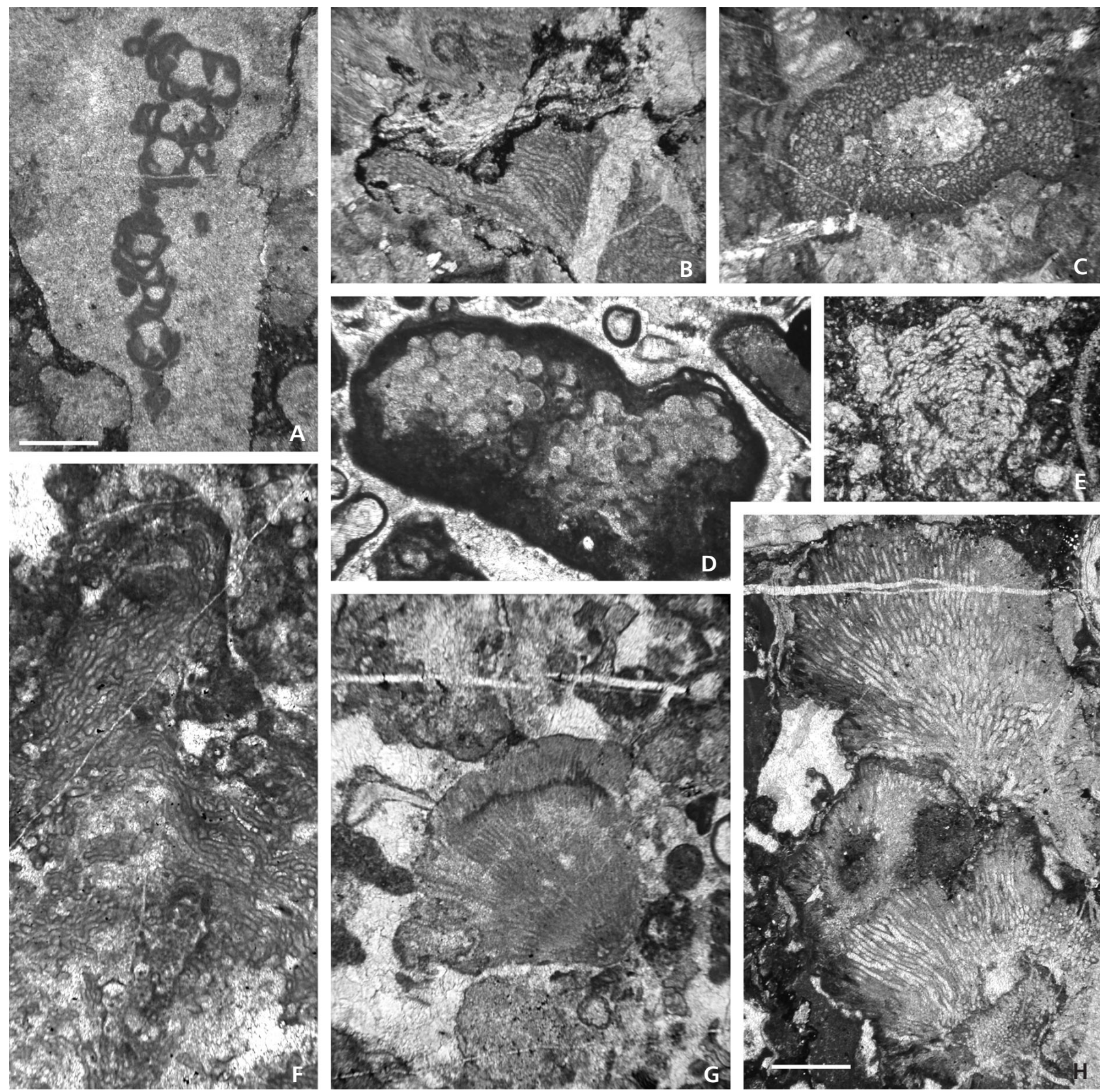

Figure 2. Late Viséan-early Serpukhovian cyanobacteria (scale bar $=0.5 \mathrm{~mm}$ except for figure $\mathrm{H}=2 \mathrm{~mm}$ ). $\bullet \mathrm{A}-$ Renalcis nubiformis (Antropov, 1955) Vachard, 1993, thin section MA-RR79, Roque Redonde, early Serpukhovian. • B - Aphralysia ferreoli Mamet \& Roux, 1975b, thin section MA-CC9B, Castelsec, early Serpukhovian. • C - Aphralysia carbonaria Garwood, 1914, thin section MA-RR40, Roque Redonde, latest Viséan. - D - Sparaphralysia tacania Vachard in Vachard \& Beckary, 1991, thin section DV-293i, Les lentilles de la route, late Viséan. E - Aphralysia capriorae Mamet \& Roux, 1975b, thin section MA-LSII-2038, La Serre-vineyard, early Serpukhovian. • F - Aphralysia ferreoli Mamet \& Roux, 1975b, thin section MA-LSFeldweg 36, La Serre-vineyard, early Serpukhovian. • G - Ortonella sp., thin section MA-RM36, Roc de Murviel, latest Viséan. • H - Anchisolenopora serrana (Vachard \& Aretz, 2004) gen. nov. Holotype, thin section MA-LSI-2043, La Serre-vineyard, early Serpukhovian.

The family Elianellaceae was assigned to incertae sedis red algae. We speculate that they are closely related to the Corallinales because several authors have described unquestionable hypothallic and perithallic structures; e.g., in Pseudochaetetes (see Peterhans 1929), Maimonochaete- tes (see Cózar \& Vachard 2006), and in a thallus of Parachaetetes from an unpublished material of M. Aretz in the Viséan of Australia. We speculate also that primitive elianellacean taxa, like Anchisolenopora gen. nov., Pseudosolenopora Mamet \& Roux, 1977 and some 
Hedstroemia Rothpletz, 1913, possibly indicate a relationship between cyanobacteria and corallinales. This hypothesis should be tested with the oldest ellianellacean genus, Bija Vologdin, 1932, often associated with numerous Cambrian cyanobacteria.

Occurrence. - Cambrian to Palaeocene, perhaps cosmopolitan.

\section{Genus Anchisolenopora gen. nov.}

Type species. - Hedstroemia (?) serrana Vachard \& Aretz, 2004.

Synonym. - Hedstroemia (pars); Solenopora (pars).

Etymology. - Greek anchi $=$ almost, and Solenopora, related genus.

Diagnosis. - Nodular, hemispherical or elongate thallus composed of numerous, densely packed tubes, round to sligthly polygonal in cross section, and sharing the same walls. Rare dichotomies occur. In axial section, partitions are absent but some rugosities are visible along the inner surface of the tubes. Wall calcitic, yellowish to brownish.

Composition. - Hedstroemia? serrana; Hedstroemia nidarosiensis Høeg, 1932 emend. Roux, 1985; cf. Hedstroemia sensu Høeg, 1932 (pl. 8, fig. 7); Hedstroemia? sp. sensu Johnson \& Høeg, 1961 (pl. 11, fig. 5); Hedstroemia sensu Riding, 1991, text-fig. 9, p. 68; Solenopora sensu Ma et al., 2014 (figs 2.3-3.3?); ?Hedstroemia? koninckoporoides Vachard, 1988; ?Pseudosolenopora owodenkoi sensu Mamet, 2002 (pl. 5, figs 10-13) non ChantonGüvenç, 1972a; ?Pycnoporidium sensu Flügel, 2004 (pl. 53, fig. 4).

Comparison. - The new genus differs from Hedstroemia by its tubes systematically in contact each with other, while in Hedstroemia only rare tubes are in contact. It differs from the algal "Solenopora" in the absence of pseudosepta, from Pseudosolenopora by the relatively loose and rounded cross-sections of tubes (no close and polygonal), and the type of wall (no dark-microgranular), from Guevencipora Vachard in Vachard et al., 1978 (and from Solenopora undata Senowbari-Daryan \& Link, 2005 which probably belongs to Guevencipora) in the absence of mural pores, and from Pycnoporidium Yabe \& Toyama, 1928 by the absence of complete transverse partitions.

Occurrence. - Ordovician of Norway (Høeg 1932, Roux
1985) and Tarim (NW China; Ma et al. 2014). Silurian of Sweden (Riding 1991). Venevian-early Serpukhovian of the Montagne Noire.

\section{Anchisolenopora serrana (Vachard \& Aretz, 2004)}

comb. nov.

Figures 2H, 9A

v. 2004 Hedstroemia (?) serrana Vachard \& Aretz, p. 649, fig. 7.3-4.

v. 2008 Anchisolenopora serrana; Pille, p. 58, pl. 18, figs 1-7 (nomen nudum).

Description. - General dimensions of thallus = $10.000-15.000 \times 8.000-10.000 \mathrm{~mm}$. Diameter of tubes $=$ $0.080-0.160 \mathrm{~mm}$.

Occurrence. - Latest Viséan (Venevian)-early Serpukhovian of the Montagne Noire (foraminiferal biozones $\mathrm{C}$ to $\mathrm{H}$ ): La Boutinelle (MA-Bou-25.19), Roc du Cayla (MA-12.14), Roque Redonde (Pc4427, MA-RR-27, MA-RR-56, MA-RR-63), Roc de Murviel (MA-28, MA-82, MA-330.4), La Serre-vineyard (MA-LS.I-2043, MA-LS.II-2035, MA-LS.III-2028, MA-LS.IV.B-2015, MA-LS.IV-B, MA-LS.Feldweg. 9, MA-LS.Feldweg. 32, DV227A).

Phylum Chlorophycophyta Papenfuss, 1955

?Class Bryopsidophyceae Bessey, 1907

?Order Bryopsidales Schaffner, 1922

?Family Udoteaceae Feldmann, 1946

\section{Genus Mellporella Rácz, 1964}

Type species. - Mellporella anthracoporellaeformis Rácz, 1964 (modified spelling for anthracoporellaformis nom. incorrect.).

Description. - Initialy described as a seletonellacean more or less similar to Anthracoporella Pia, 1920 (Rácz 1964, Poncet 1986 and Mamet 1991), this taxon belongs most probably to another algal group.

Occurrence. - Late Bashkirian-Moscovian; Spain and Algeria.

\section{Genus Mellporella?}

Description. - Subsegmented Udoteaceae with simple, elongate thallus; broad medullar zone not calcified; cortical zone with numerous, constituted by undulating, me- 

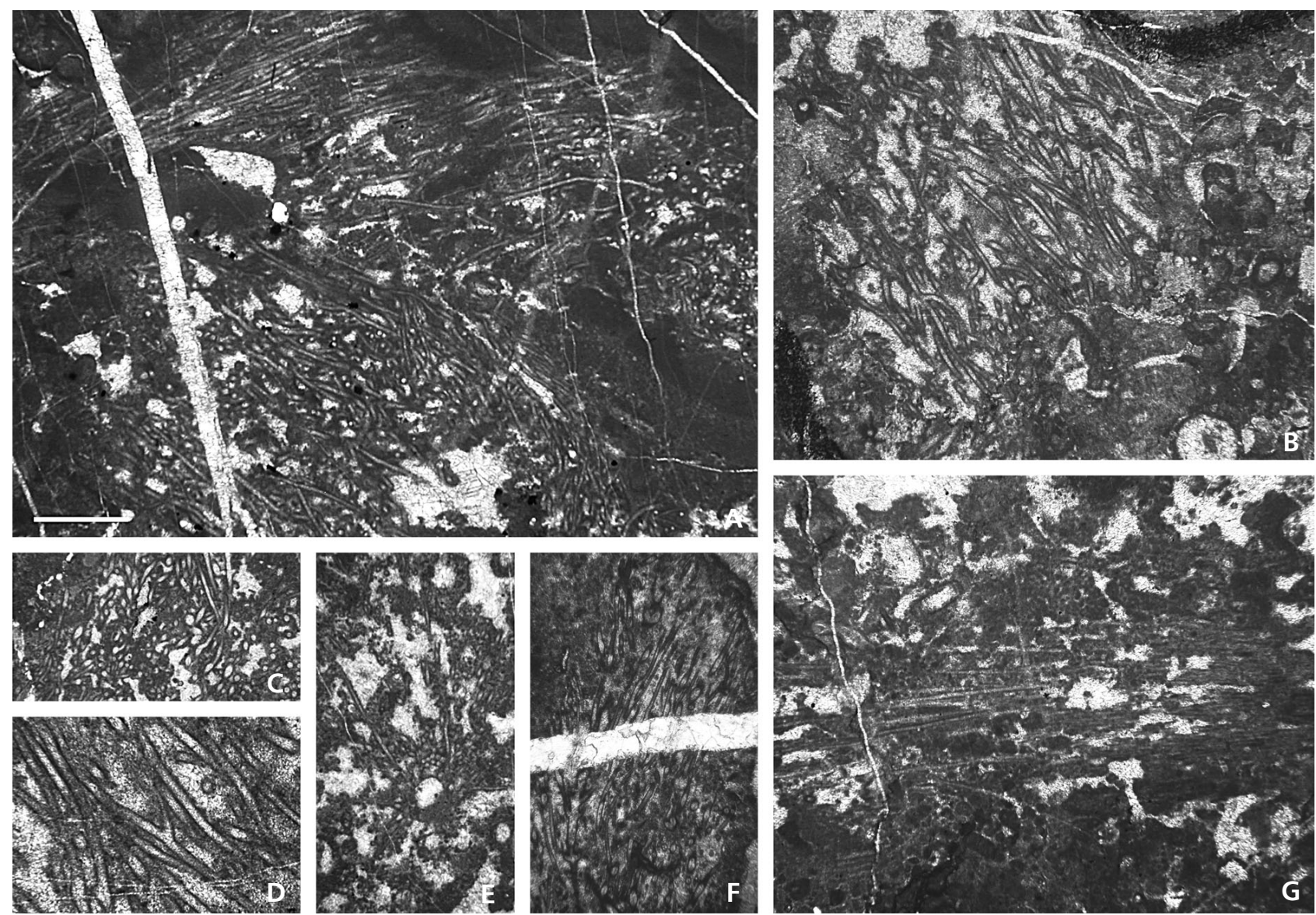

Figure 3. Latest Viséan-earliest Serpukhovian Ortonellopsis laxa gen. et sp. nov. (scale bar $=1 \mathrm{~mm}$, except for figures $\mathrm{C}, \mathrm{E}=0.5 \mathrm{~mm}$ and $\mathrm{D}=0.25 \mathrm{~mm}) \cdot \bullet \mathrm{A}$ - paratype. Thin section MA-RM78, Roc de Murviel, earliest Serpukhovian. $\bullet B$ - paratype. Thin section MA-RM83, Roc de Murviel, earliest Serpukhovian. $\bullet$ C - paratype. Thin section MA-RM20, Roc de Murviel, latest Viséan. $\bullet$ D - holotype. Thin section MA-RM83, Roc de Murviel, earliest Serpukhovian. $\bullet$ E - paratype. Thin section MA-RM20, Roc de Murviel, latest Viséan. • F - paratype. Thin section Pc-4401, Roque Redonde, latest Viséan. $\bullet \mathrm{G}$ - paratype. Thin section MA-LSV-2004, La Serre-vineyard, earliest Serpukhovian.

dium to broad threads, dichotomous, randomly arranged; white neomicrosparitized wall.

Remarks. - It is also possible that our material belongs to Hikorocodium Endo, 1951 sensu lato; first described as a codiale as indicated by its name but then assigned to the ischyrospongia or hypercalcified sponges (Vachard 1976, Termier et al. 1977, Senowbari-Daryan \& Rigby 2007, Mamet \& Préat 2013). On the other hand, the recently described species Hikorocodium rhenaensis Mamet \& Préat, 2013 is most probably an algosponge Sinustacheoides or Epistacheoides.

Occurrence. - Early Serpukhovian of the Montagne Noire (this study); ?latest Viséan-Serpukhovian-Bashkirian of Algeria (Oubeur Formation, Namurian A of Bechar Basin, $\mathrm{E}_{2}-\mathrm{H}$ ammonoid biozones of Tagnana Fm, early Bashkirian of upper Tagnana Fm, Westphalian A of Jebel Mezarif (Lemosquet \& Poncet 1977, Poncet
1986, Sebbar \& Lys 1989, Sebbar 1990, Sebbar \& Mamet 1996); early Bashkirian of northern Spain (Vachard \& Beckary 1991).

\section{Mellporella? aff. "magnum" (sensu Lemosquet \& Poncet, 1977 non Endo, 1951)}

Figure 5A-D

Compare with

1977 Anchicodium magnum; Lemosquet \& Poncet, p. 337, pl. 8, figs $1-6$.

1986 Melporella (sic) anthracoporellaformis; Poncet, p. 188, pl. 1, figs $1-5$.

1989 Anchicodium magnum; Sebbar \& Lys, pl. 1, fig. 3.

1990 Anchicodium magnum; Sebbar, pl. 1, fig. 2.

1991 Mellporella anthracoporellaeformis; Vachard \& Beckary, p. 323, pl. 1, figs 6, 7. 

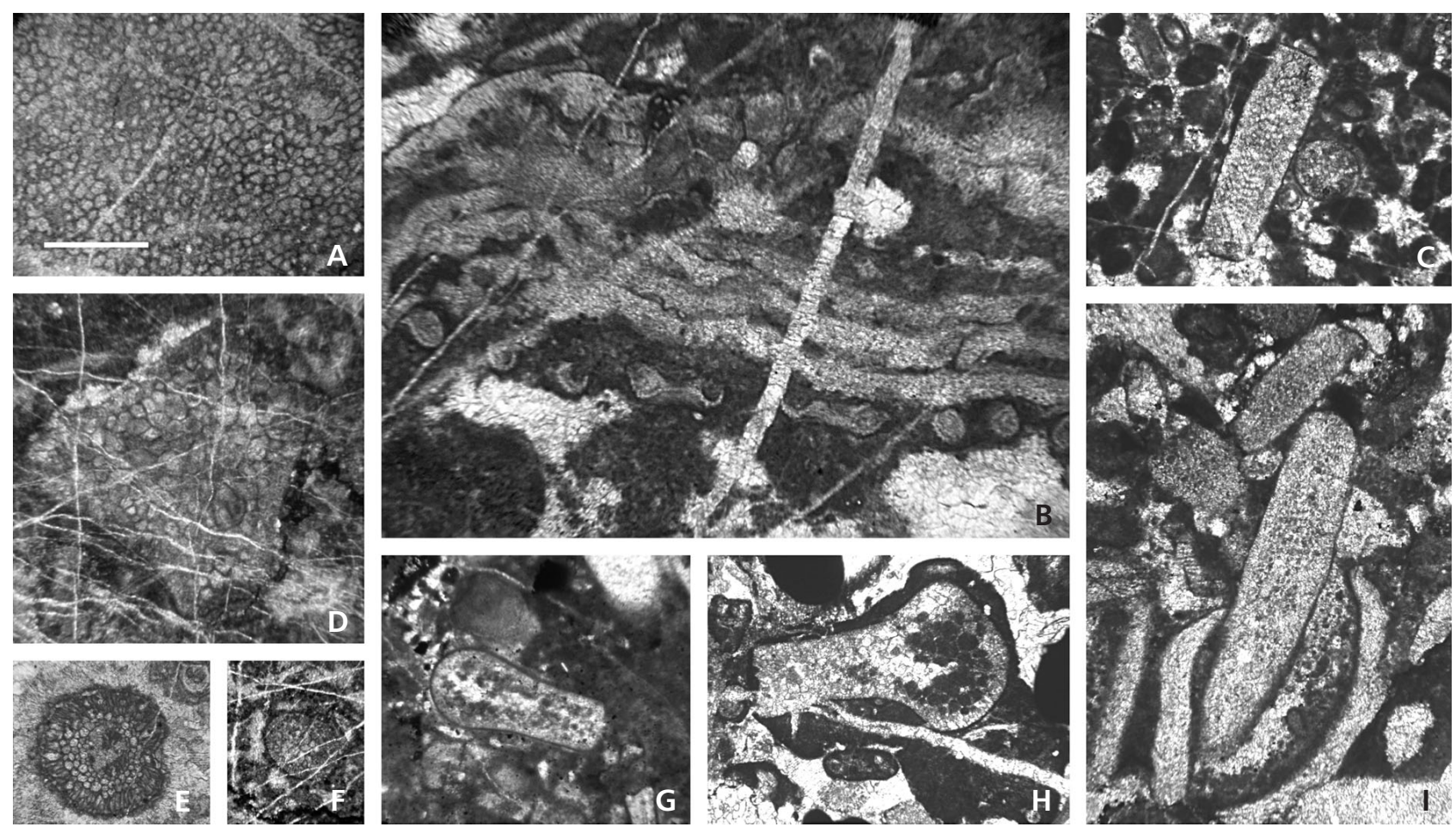

Figure 4. Late Viséan-early Serpukhovian Rhodophyta (scale bar =0.5 mm). • A - Anchisolenopora serrana (Vachard \& Aretz, 2004) gen. nov. Paratype, thin section MA-CC9A, Castelsec, early Serpukhovian. • B - Archaeolithophyllum lamellosum Wray, 1964, thin section MA-SP18, La Serre de Péret, early Serpukhovian. • C - Neoprincipia fluegeli (Vachard in Krainer \& Vachard, 2002), thin section MA-LSI-2049, La Serre-vineyard, early Serpukhovian. • D - Neoprincipia guadiatica Cózar \& Vachard, 2003, thin section MA-CC1, Castelsec, early Serpukhovian. • E - Hortonella uttingi Mamet, 1995, thin section MA-RR39, Roque Redonde, latest Viséan. • F - Neoprincipia petschoriaeformis Vachard \& Aretz, 2004, thin section MA-CC1, Castelsec, early Serpukhovian. • G - Neoprincipia claviformis Vachard \& Aretz, 2004, thin section, MA-LSIII-2021, La Serre-vineyard, early Serpukhovian. • H - Neoprincipia guadiatica Cózar \& Vachard, 2003, thin section DV-126f, Japhet, late Viséan. • I - Neoprincipia fluegeli (Vachard in Krainer \& Vachard, 2002), thin section MA-LSI-2044, La Serre-vineyard, early Serpukhovian.

1996 Anchicodium sp.; Sebbar \& Mamet, pl. 2, figs 12, 13.

Description. - Maximal length $=8.800-12.450 \mathrm{~mm}$, outer diameter $=3.000-5.000 \mathrm{~mm}$, inner diameter $=1.700-2.700 \mathrm{~mm}$, thickness of skeleton $=0.700-1.300 \mathrm{~mm}$.

Occurrence. - Early Serpukhovian (Steshevian) of the Montagne Noire in La Serre de Péret (MA-SP-20, MA-SP-30).

Order ?Ulotrichales Borzi, 1895

Family Anatoliporaceae Vachard et al., 1989 emend. herein

Synonym. - Salpingoporellinae Bassoullet et al., 1979 (pars; see Bassoullet et al. 1979, Roux 1985, Chuvashov et al. 1987, and Mamet 1991).

Emended diagnosis. - Attached colonies, composed of several thalli prostrate, domed, club-shaped to cylindrical. Central narrow cavity, or reduced to an enlargment at the base of the laterals. Laterals numerous, aspondyl, phloiophore with strong oblique insertion, rectilinear or with slight curvature. Wall microsparitized.

Emended composition. - Anatolipora; Richella; Tegumentupecten May, 1992; Cylindrifolia Brenckle \& Groves, 1987.

Comparison. - The Anatoliporaceae differ from the true Dasycladales in the small central cavity, the numerous, oblique, aspondyl laterals. They differ from the Seletonellaceae in the numerous thalli assembled in a colony, and from the Vermiporellaceae Saltovskaya in Chuvashov et al., 1987 in the small size, the less triangular extremities, the colonial grouping, but the Vermiporellaceae are the most similar group. Consequently, if admitted the assignment of Vermiporella Stolley, 1893, ex Pia, 1927, proposed by some authors (Kozlowski \& Kazmierczak 1968, Emberger 1976), this family can belong to the Ulotrichales. A possible Carboniferous ulotrichacean should be the late Viséan Vermiporella shartymensis Kulik, 1973; nevertheless, this latter species is 

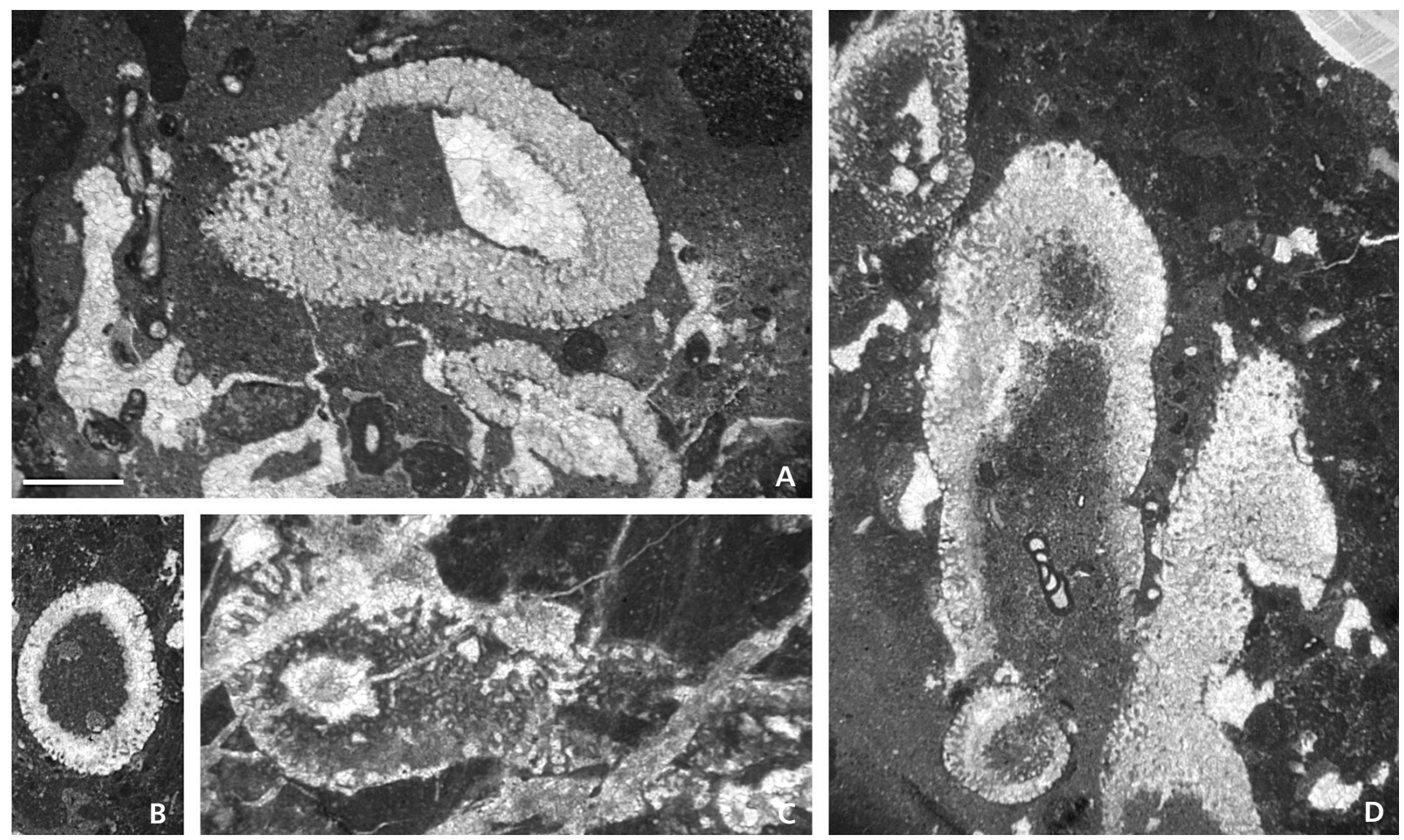

Figure 5. Early Serpukhovian Mellporella? aff. "magnum" [sensu Lemosquet \& Poncet, 1977 non Endo, 1951] (scale bar = 2 mm), La Serre de Péret, early Serpukhovian. • A, B, D - thin section MA-SP20. • C - thin section MA-SP30.

difficult to interpret and might also belong to Issinella, Crassikamaena or Luteotubulus Vachard in Vachard et al., 1977.

Remarks. - The family Anatoliporaceae is emended herein in order to encompass (a) Anatolipora, (b) Richella which appears similar to Anatolipora in the organization of laterals, (c) Tegumentupecten which is morphologically similar to Richella; and (d) Cylindrifolia which is totally atypical for a dasycladale bona fide.

Occurrence. - Questionable in the Devonian and late Tournaisian. Brigantian-late Serpukhovian. Doubtful in the Pennsylvanian with Anatolipora cantabriensis Mamet \& Villa, 2004.

\section{Genus Anatolipora Konishi, 1956 emend. herein}

Type species. - Anatolipora carbonica Konishi, 1956.

Emended diagnosis. - Colonies composed of several club-shaped to cylindrical thalli. Each thallus has a narrow central cavity, numerous branches, aspondyl, phloiophore with strong oblique insertion and slight curvature. The wall is microsparitized and probably initially aragonitic.
Composition. - Anatolipora carbonica; A. carbonica sensu Buchroithner et al., 1980; A. cantabriensis Mamet \& Villa, 2004; A. macroporelloidea Vachard \& Cózar sp. nov.

Remarks. - Even if fragments of Anatolipora may be confused with dasycladales, entire colonies are completely different, and more similar to vermiporellacean algae; however, Anatolipora differs from these latter by the forms of laterals and smaller size of thalli. On the other hand, the genus Richella which seemed totally atypical among the algae, may be related with Anatolipora, by its type of laterals, although it differs by its attached growth.

Occurrence. - Latest Viséan (Brigantian) to late Serpukhovian (Arnsbergian). Japan, Montagne Noire, Pyrenees, Spain, Belgium, ?Algeria, Alaska, and Alberta (Mamet 1991).

\section{Anatolipora carbonica Konishi, 1956 emend. herein} Figure $6 \mathrm{~A}-\mathrm{C}, \mathrm{E}, \mathrm{G}-\mathrm{I}$

p. 1956 Anatolipora carbonica Konishi, pp. 121, 123, pl. 1 , figs 1,2 ?, $3,4,7$, pl. 2 , fig. 4 ; text-fig. $1 \mathrm{a}, \mathrm{b}$ 
(nevertheless, the idealized euspondylity is misinterpreted); non pl. 1, figs 5, 6, 8, 9, pl. 2, figs $1-3,5$ ? $(=$ Windsoporella $)$.

non 1961b Anatolipora carbonica; Endo, pp. 131-132, pl. 7, fig. 3 (= indeterminate dasycladale).

1971 Anatolipora; Kochansky-Devidé \& Gusic, p. 86 (bottom, right), text-fig. 4.

v. p. 1974b Anatolipora carbonica; Vachard, pp. 176-177, pl. 7, fig. 7 (non pl. 5, fig. $6=$ Cabrieropora pokornyi).

p. 1976 Anatolipora carbonica; Emberger, p. 18 (no illustration).

v. 1977a Anatolipora carbonica; Vachard, p. 374, table 1 (no illustration).

v. 1977b Anatolipora carbonica; Vachard, p. 134, pl. 1, fig. 9.

non 1978 Anatolipora aff. carbonica; Mamet et al., pp. 363-364, pl. 5, fig. 15 (a true dasyclad).

non 1980 Anatolipora carbonica; Buchroithner et al., pp. 22-23, pl. 4, figs 1, 2, 3?.

1980 Nanopora anglica; Buchroithner et al., p. 25, pl. 5, fig. 5.

1985 Anatolipora carbonica Konishi (= Anthracoporella bashkirica). - Herbig \& Mamet, pl. 1, fig. 8.

1988 Anatolipora carbonica; Deloffre, pl. 9, fig. 18.

v. 1989 Anatolipora carbonica; Vachard et al., p. 704, pl. 1, fig. 9 (with synonymy).

2002 Anatolipora carbonica; Mamet, p. 498, pl. 3, figs 4-10 (with synonymy).

non 1989b Anatolipora carbonica; Nguyen Duc Tien, pl. 23, figs 6-9 (aspondyl and metaspondyl dasyclads).

v. 1994 Anatolipora carbonica; Delvolvé et al., p. 190, 193 (no illustration).

? 1997 Richella incrustata; Harris et al., fig. 9. 25.

v. 1998 Anatolipora carbonica; Delvolvé et al., p. 366 (no illustration).

non 1999 Anatolipora carbonica; Sebbar \& Mamet, text-fig. 3.84, pl. 2, fig. 14 (a dasyclad because of the broad central cavity).

p. 2000 Anatolipora carbonica; Granier \& Grgasovic, pp. 9-10 (with synonymy) (no illustration).

2000 Anatolipora sp.; Sebbar, pl. 1, fig. 8.

2008 Anatolipora carbonica; Pille, p. 27, pl. 6, figs 1-12.

Emended diagnosis. - Anatolipora with up to seven bifurcated thalli, exhibiting a narrow central cavity and numerous simple laterals which are acrophore, gently curved, regularly alternating and separated by a relatively broad interlateral calcified space.

Description. - Maximal length $=4.000 \mathrm{~mm}$, outer diameter $=0.300-0.610 \mathrm{~mm}$, inner diameter $=0.060-0.130 \mathrm{~mm}$, thickness of skeleton $=0.150-0.260 \mathrm{~mm}$, proximal diameter of laterals $=0.015-0.020 \mathrm{~mm}$, distal diameter of laterals $=0.025-0.033 \mathrm{~mm}$.
Remarks. - Paradoxically, Anatolipora carbonica possessed two "holotypes". The first one was a relatively atypical transverse section illustrated by Konishi (1956, pl. 1, fig. 2); the second one (pl. 1, fig. 4) was an axial section. This latter corresponds to the thallus reconstruction of Konishi (1956, p. 120, text-fig. 1) and to the specimens generally assigned to Anatolipora by Mamet \& Rudloff (1972), Vachard (1977b), and Herbig \& Mamet (1985). Hence, we designate here, as unique type (lectotype) and generotype, the pl. 1, fig. 4 of Konishi (1956). Furthermore, a part of the type material corresponds to sections of Windsoporella Mamet \& Rudloff, 1972 emend. Vachard, 1980 (e.g., pl. 1, figs 5, 6, 8, 9, pl. 2, figs $1-3)$.

On the other hand, the illustrations of Homann (1972), first revised by Vachard et al. (1989), can be re-interpreted as follows: The fig. 24 is a small Mizzia sp., fig. 45 is a cribrate aperture of Climacammina sp., and fig. 54 is a polyaxone sponge spicule.

Furthermore, Herbig \& Mamet (1985, pl. 1, fig. 8) have suggested that Anatolipora carbonica Konishi could be synonymized with Anthracoporella bashkirica Kulik, 1973. In our opinion, these taxa differ; nevertheless, Anthracoporella bashkirica is possibly an ulotrichale. Similarly, the specimens of Anatolipora carbonica of Buchroithner et al. (1980) correspond to another ulotrichale taxon; however, true Anatolipora carbonica are present in the assemblages described by Buchroithner et al. (1980), although erroneously designated as Nanopora anglica.

Occurrence. - As for the genus; in the Montagne Noire, Mikhailovian-Steshevian (late Viséan-early Serpukhovian = foraminiferal biozones A to G): Castelsec (Pc-4523, Pc-4537, MA-11.9.1.Quer, MA-11.9.1. Längs, MA11.9.3, MA11.10); Roc du Cayla (Pc-4578, Pc-4584, Pc-4585, Pc-4603, MA-12.18, MA-12.22, DV84A, DV465B); Roque Redonde (MA-RR2, MA-RR27, MA-RR31, MA-RR35, MA-RR51, MA-RR52, MA-RR53, MA-RR54, MA-RR55, MA-RR56, MA-RR57, MA-RR59, MA-RR60, MA-RR62, MA-RR63, MA-RR69, MA-RR71, MA-RR73, MA-RR74, MA-RR76?, MA-RR79, MA-RR84?, MA-RR88); La Boutinelle (Pc-4656, Pc-4653, Pc-4649, MA-Bou25.5, MA-Bou25.7, MA-Bou25.8, MA-Bou25.9, MA-Bou25.9B, MA-Bou25.12, MA-Bou25.14, MA-Bou25.18, MA-Bou25.19); Tiberet (ML.FSL.TIB); Château-Vailhan (Pc-4709, Pc-4721, Pc-4724, Pc-4725, Pc-4734, Pc-4738, Pc-4740, Pc-4741, Pc-4742, Pc-4743, Pc-4744, DV232A); Roc de Murviel (MA-8, MA-9, MA-21, MA-26, MA-50, MA-70, MA-73.2, MA-33.82, MA-33.83, MA-330.4, MA-330.5, MA330.11, Pc-4462, Pc-4913, DV251B); La Serre de Péret (MA-SP.18); northern slope of Les Batailles hill (DV612A, DV611B). Late Serpukhovian in the Pyrenees: Ardengost (MFP.AH81.1). 

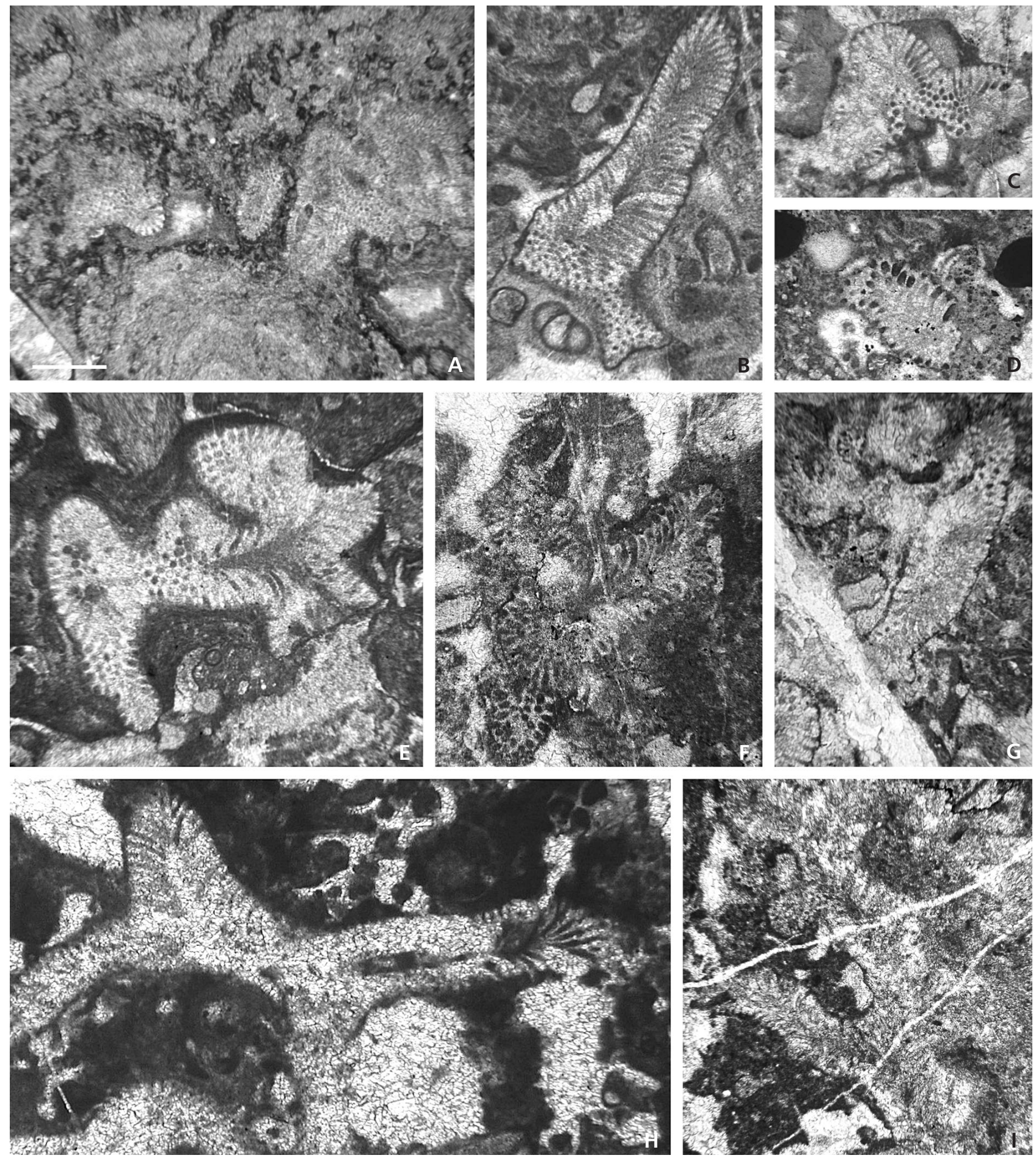

Figure 6. Late Viséan-early Serpukhovian Anatoliporaceae (scale bar =0.5 mm). A-C, E, G-I - Anatolipora carbonica Konishi, 1956 emend. herein. - A - thin section MA-CC2, Castelsec, early Serpukhovian. • B - thin section MA-RR31, Roque Redonde, latest Viséan. • C - thin section MA-RM36, Roc de Murviel, latest Viséan. • E - thin section MA-33-83, Roc de Murviel, latest Viséan. • G - thin section MA-330-5, Roc de Murviel, early Serpukhovian. - H - thin section MA-11-10, Castelsec, early Serpukhovian. - I - thin section PC4735, Château-Vailhan, latest Viséan. $\bullet$ D, F - Anatolipora macroporelloidea sp. nov. $\bullet$ D - paratype. Thin section DV-605A (USTL 1307), Mounio, late Viséan. $\bullet$ F - holotype. Thin section DV-609 (USTL 1308), Les Batailles, late Viséan. 


\author{
Anatolipora macroporelloidea Vachard \& \\ Cózar sp. nov. \\ Figure 6D, F
}

2008 Anatolipora macroporelloidea Pille, p. 28, pl. 6, figs 13-18 (nomen nudum).

Etymology. - Comparable to the seletonellacean dasyclad Macroporella Pia, 1912.

Locus typicus. - Northern slope of Les Batailles hill, near Cabrières village (Hérault, France).

Stratum typicum. - Venevian.

Holotype. - Fig. 6F (sample DV609); collection number USTL 1308.

Type material. - Approximately 60 specimens (in 30 thin sections).

Diagnosis. - Anatolipora characterized by wide laterals and thinner interlateral calcification.

Description - Maximal length $=2.220 \mathrm{~mm}$, outer diameter $=0.315-0.500 \mathrm{~mm}$, inner diameter $=0.075-0.130 \mathrm{~mm}$, thickness of skeleton $=0.120-0.175 \mathrm{~mm}$, proximal and distal diameters of laterals $=0.055-0.075 \mathrm{~mm}$.

Repository of the types. - Collection of Palaeontology of the Lille University (numbers 1307-1308).

Comparison. - It differs from A. carbonica by the larger size of the colonies and the broader laterals.

Remarks. - Anatolipora macroporelloidea, although rare in the Montagne Noire, could represent one of the biomarkers of the latest Viséan-earliest Serpukhovian bounday interval, because of its association with (a) the foraminiferal assemblage of Les Batailles hill, and (b) with Neoprincipia petschoriaeformis Vachard \& Aretz, 2004 in the basal flysch levels of Mounio-Cabrières.

Occurrence. - Venevian-Steshevian of the Montagne Noire (foraminiferal biozones $D$ to $G$ ): La Boutinelle (MA-Bou.25.9b, MA-Bou.25.19), Castelsec (Pc-4522, Pc-4545, Pc-4560, MA-11.1.9p), Roc du Cayla (Pc-4582, Pc-4586, MA-12.18, MA-12.22), Château-Vailhan (Pc-4730, Pc-4735, Pc-4737, Pc-4740, Pc-4741, Pc-4742, Pc-4743, Pc-4744), Roque Redonde (Pc-4418, Pc-4412, Pc-4411, Pc-4404, Pc-4398, Pc-4397, MA-RR52), Roc de Murviel (MA-RM-36, MA-33.82, MA-33.83, MA-330.05), northern slope of Les Batailles hill (DV612A), and Mounio-Cabrières (DV605B).
Class Chlorophyceae Kützing, 1843

Order Dasycladales Pascher, 1931

Family Seletonellaceae (Kordé, 1950 nom. translat. Kordé, 1973) ex Bassoullet et al., 1979

Description. - This family corresponds to the aspondyl dasycladaleans (e.g., Bassoullet et al. 1979; Roux 1985; Deloffre 1987, 1988).

Occurrence. - ?Cambrian-Ordovician-Early Cretaceous; cosmopolitan.

Tribe Epimastoporeae Vachard, Krainer \& Lucas, 2012

Description. - Large fragments of cylindrical, club-shaped or most commonly subspherical dasycladales. Broad central cavity and relatively thin walls. Lateral simple, numerous, aspondyl but almost euspondyl, and having some shapes relatively uncommon among the dasycladales; e.g., prismatic, "clepsydral" (see Baratollo et al. 1993), ellipsoidal sometimes very inflated in the centre, and dumbbell-like (perhaps in relation with a unknown mode of reproduction). They communicate with the exterior by a small pore or apparently have no preserved connections (Globuliferoporella). Outer and inner surfaces generally smooth but intusannulations exist in Paraepimastopora. Wall whitish microsparitized, probably initially aragonitic.

Composition. - Epimastopora (Pia, 1922) Kochansky-Devidé \& Herak, 1960; Kahaganella Falahatgar et al., 2015; Palaepimastoporella Cózar \& Vachard, 2004; Paraepimastopora Roux, 1979 emend. Krainer \& Vachard, 2002; "Epimastopora" in the sense of Rácz (1964, 1966; with E. bodoniensis Rácz, 1964; E. camesobresensis Rácz, 1966, E. rolloensis Rácz, 1964); Globuliferoporella Chuvashov, 1974; ?Borisovella Ivanova, 1988; ?Sphenoporella Chuvashov, 1974; and ?"Embergerella" Güvenç, 1972 pre-occupied (see Cózar \& Vachard 2004). See also the descriptions of the subtribe Epimastoporellineae Cózar \& Vachard (2004) and tribe Epimastoporeae Vachard et al. (2012).

Occurrence. - Late Tournaisian-Late Permian; cosmopolitan in the Late Pennsylvanian-Early Permian, or otherwise Palaeotethyan.

\section{Genus Paraepimastopora Roux, 1979 emend. Krainer \& Vachard, 2002}

Synonyms. - Epimastopora "Pia, 1922" (pars); Anthracoporella Pia, 1920 (pars), Anchicodium Johnson, 1946 (pars). 

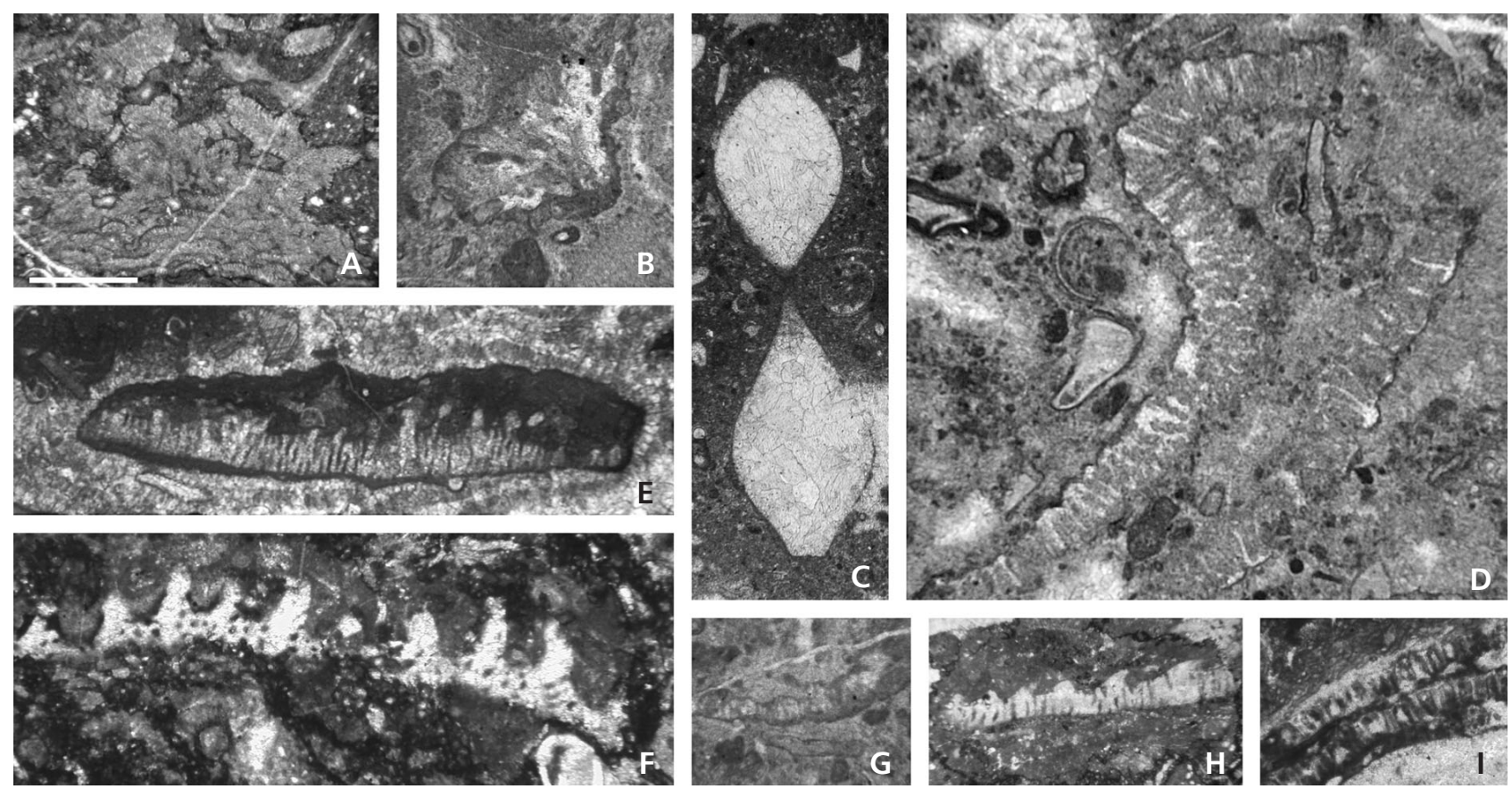

Figure 7. Late Viséan-early Serpukhovian Chlorophyta (scale bar =1 mm). A - Richella incrustata Mamet \& Roux in Mamet et al., 1987; thin section MA-CC2, Castelsec, early Serpukhovian. • B - Orthriosiphon? sp., thin section MA-RR73, Roque Redonde, early Serpukhovian. • C - Saccamminopsis fusulinaeformis McCoy, 1849, thin section DV-325, Roc de Loup-Vailhan, late Viséan. • D - Palaepimastoporella espielensis Cózar \& Vachard, 2004, thin section MA-RR81, Roque Redonde, early Serpukhovian. $\bullet$ E-H - Paraepimastopora somervillei sp. nov. $\bullet$ E - holotype. Thin section MA.BOU25.8, La Boutinelle, latest Viséan. $\bullet \mathrm{F}$ - paratype. Thin section MA-LS Feldweg 10, La Serre-vineyard, early Serpukhovian. $\bullet$ G - paratype. Thin section MA-RR73, Roque Redonde, early Serpukhovian. - H - paratype. Thin section MA-LS Feldweg 33, La Serre-vineyard, early Serpukhovian. - I - Palaepimastoporella espielensis Cózar \& Vachard, 2004, thin section MA-LS Feldweg 36, La Serre-vineyard, early Serpukhovian.

\section{Type species. - Epimastopora kansasensis Johnson, 1946.}

Diagnosis. - Thallus probably cylindrical or club-shaped with rather large central cavity, poorly calcified and often broken. Skeleton perforated by numerous, thin, aspondyl, simple, acrophore laterals, closely spaced, and with relatively thickly calcified interpores. Regular intusannulations are generally well developed.

Composition. - Epimastopora kansasensis Johnson, 1946, E. jewetti Johnson, 1946; E. kanumai Endo in Endo \& Kanuma, 1954; E. lateinterporosa Endo, 1961b; E. longituba Endo, 1957; E. malaysiana Elliott, 1968b; E. regularis Johnson, 1946; E. urtazymensis Chuvashov \& Anfimov, 1988; Paraepimastopora noetschensis Krainer \& Vachard, 2002; P. grandis (Chuvashov \& Anfimov) sensu Mamet \& Préat, 2010; P. peytoni Mamet \& Préat, 2013; P. somervillei sp. nov.

Remarks. - Contrary to Granier \& Deloffre (1995), Paraepimastopora and Tauridium are distinct because Tauridium Güvenç, 1966 is only a stage of preservation of Permocalculus as well as Dzhulfanella or Pyrulites (Vachard et al. 2005). Furthermore, Paraepimastopora sensu Brenckle \& Groves (1987, fig. 12.4) are misinterpreted and more pro- bably corresponds to a tangential section of Cylindrifolia. In contrast, "Orthriosiphon" of these authors (Brenckle \& Groves 1987, fig. 12.16-17) are possibly epimastoporaceans similar to Kahanagella (see Falahatgar et al. 2015).

Occurrence. - Late Asbian-early Serpukhovian of Spain (Sánchez-Chico et al. 1995; Cózar \& Somerville 2005b, p. 80). Early Brigantian of central Morocco (unpublished data). Brigantian of Ireland (Cózar \& Somerville 2005b, text-fig. 3). Venevian-early Serpukhovian of southern France (this study) and Oklahoma, U.S.A. (Groves 1983, Mamet \& Préat 2013). The acme of this genus occurs during the Pennsylvanian-Cisuralian; it disappears probably in the Guadalupian. Northwestern Palaeotethyan during the early Mississippian; then, it becomes cosmopolitan.

\section{Paraepimastopora somervillei Vachard \& Cózar sp. nov.}

Figure 7E-H

?1973 Orthriosiphon? - Maslov, pl. 2, fig. 6 (or other species of the genus).

?p. 1974 Zaporella? sp. - Rich, pl. 1, fig. 11 (non fig. $14=$ = Richella). 
?1995 Parapimastopora sp. - Sánchez-Chico et al., p. 73, pl. 3, fig. 12.

?1996 Paraepimastopora sp. - Sebbar \& Mamet, pl. 2, fig. 4.

?1999 Paraepimastopora sp. - Sebbar \& Mamet, pl. 1, fig. 8.

?2003 Paraepimastopora sp. - Mamet \& Misik, fig. 3.1-3.

v. 2004 Paraepimastopora sp. - Vachard \& Aretz, p. 652, fig. 8.5.

?v. 2004 Paraepimastopora sp. - Cózar, text-fig. 3, p. 371, text-fig. 4, p. 372 (no illustration).

v. 2004a Paraepimastopora sp. - Cózar \& Vachard, fig. 4.11.

v. 2004 Paraepimastopora? sp. - Cózar \& Somerville, p. 45, text-fig. 3 , p. 47 , text-figs 6,8 , p. 48 , text-fig. 9 , p. 49 , figs $13.4,13.7,14.28$.

v. ?2005 Paraepimastopora sp. - Karim et al., fig. 3H.

v. 2005 Paraepimastopora (?) sp. - Cózar, text-fig. 4, p. 409 , fig. 7.19 .

v. 2005a Paraepimastopora? sp. - Cózar \& Somerville, p. 25, text-fig. 16.

v. 2005b "Paraepimastopora" sp. - Cózar \& Somerville, pl. 1, fig. 15.

v. 2005c Paraepimastopora sp. - Cózar \& Somerville, fig. 4.9.

v. 2008 Paraepimastopora cozarii Pille, p. 34, pl. 9, figs 3-5 (nomen nudum).

Etymology. - Dedicated to Prof. Ian Somerville (Dublin), for his work in Early Carboniferous micropalaeontology and biostratigraphy.

Locus typicus. - La Boutinelle (Hérault, France).

Stratum typicum. - Venevian.

Holotype. - Fig. 7E (sample MA.BOU25.8); Collection M. Aretz, Toulouse.

Diagnosis. - Small species, with small diameter and intusannulation not hollow.

Description.- Maximal length of thallus $=5.000-6.000 \mathrm{~mm}$, wall thickness $=0.600 \mathrm{~mm}$, diameter of pores $=0.050 \mathrm{~mm}$, interpore space $=0.150 \mathrm{~mm}$.

Type material. -47 specimens.

Repository of the types. - Collection M. Aretz, Toulouse.

Comparison. - The new species differs from $P$. noetschensis Krainer \& Vachard, 2002 in the dimensions and the not hollow intusannulations and from $P$. peytoni Mamet \& Préat, 2013, very poorly described and illustrated, by its broader pores.
Occurrence. - Late Asbian-early Serpukhovian of Spain, Brigantian of Ireland, Serpukhovian of Bechar Basin (Algeria), Asbian/Brigantian of central Morocco, early Brigantian of northern England and Brigantian of the Slovak Republic. Venevian of La Boutinelle (MA.BOU25.8) and slope of Batailles hill (DV607D). Latest Viséan (Venevian)-early Serpukhovian (Steshevian) (foraminiferal zones D to G) of La Serre-vineyard (MA.LS.Feldweg10) (see also Vachard \& Aretz 2004: GIK 1801; GIK1814).

Family Diploporaceae Pia, 1920 nom. translat. Shuysky (1987) non Deloffre (1987) nec Deloffre (1988) emend. Pille \& Vachard, 2011

Diagnosis. - Cylindrical to segmented metaspondyl dasycladales.

Composition. - During the Palaeozoic, the family Diploporaceae encompasses three tribes: Velebitelleae Vachard, 1977b, Albertaporelleae Güvenç, 1979 nomen translat. Deloffre, 1988, and Diploporeae Pia, 1920 nomen translat. Güvenç, 1979. This number is probably greater due to: 1) the little knowledge of the uppermost Devonian-lowermost Mississippian Diploporaceae, despite of the numerous studies in e.g., Belgium, Ukraine, European Russia and Siberia; 2) the great differentiation of the diploporacean genera during the Mesozoic, the Palaeozoic ancestors of which are not yet well known.

Like new diplopore dasycladales from the Montagne Noire were recently published by Pille \& Vachard (2011), only the status of two tribes is revised herein, Velebitelleae and Borladelleae trib. nov.

Occurrence. - Early Devonian to Triassic, generally confined to the Tethys and Ural oceans; rarely in the shelves of the North American craton.

Tribe Velebitelleae Vachard, 1977b emend. Pille \& Vachard, 2011

Diagnosis. - Vestibuled and articulated Diploporaceae, with acrophore, phloiophore or vesiculifer laterals, and with cylindrical to subspherical articles more or less individualized.

Composition. - Two subtribes: (1) Velebitellinae Vachard, 1977b nom. translat. Bassoullet et al., 1979; (2) Kulikiinae Pille \& Vachard, 2011.

Occurrence. - Early Devonian to Late Permian, generally confined to the Tethys and Ural oceans; rarely described in the coeval shelves of the North American craton. 

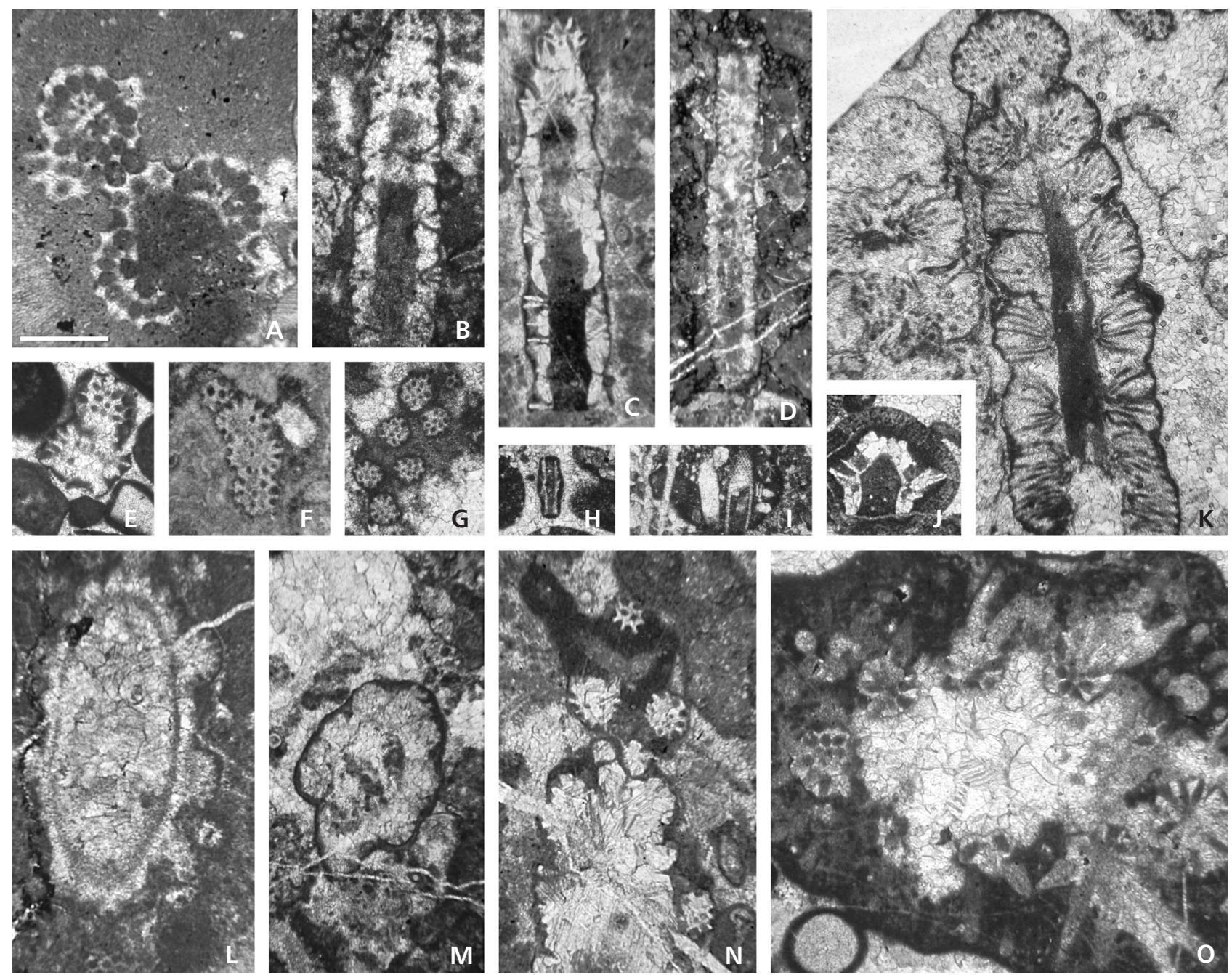

Figure 8. Late Viséan-early Serpukhovian dasycladales (scale bar $=0.5 \mathrm{~mm}$ except for figure $\mathrm{K}=1 \mathrm{~mm}$ ). $\bullet \mathrm{A}-$ Kulikia sphaerica Golubtsov, 1961 , thin section MA-RR15, Roque Redonde, latest Viséan. - B - Windsoporella solida Pille \& Vachard, 2011, thin section Pc-4549, Castelsec, early Serpukhovian. • C - Windsoporella tulayae (Chanton-Güvenç, 1972b) ex Pille \& Vachard, 2011, thin section MA-RM37, Roc de Murviel, latest Viséan. -D - Guadiatella heraldica Pille \& Vachard, 2011, thin section MA-Feldweg 10, La Serre-vineyard, early Serpukhovian. • E - Cabrieropora pokornyi Mamet \& Roux, 1975a, thin section DV-856, Japhet, late Viséan. • F - Cabrieropora pokornyi Mamet \& Roux, 1975a, thin section MA-CC2, Castelsec, early Serpukhovian. - G - Cabrieroporellopsis inopinatus Pille \& Vachard, 2011, thin section Pc-4556, Castelsec, early Serpukhovian. - H - Windsoporella pareyni (Mamet \& Roux, 1975a), thin section Pc-4702, La Serre de Péret, early Serpukhovian. • I - Nanopora anglica Wood, 1964, thin section DV-126g, Japhet, late Viséan. • J - Windsoporella longirostris Pille \& Vachard, 2011, thin section Pc-4702, La Serre de Péret, early Serpukhovian. $\bullet$ K - Eovelebitella occitanica Vachard, 1974a, thin section Pc-4557, Castelsec, early Serpukhovian. $\bullet$ L - Murvielopora aretzii Pille \& Vachard, 2011, thin section MA-33-53, Roc de Murviel, latest Viséan. • M - Borladella cf. alternans Cózar et al., 2007, thin section MA-RM36, Roc de Murviel, latest Viséan. - N - Cabrieroporellopsis inopinatus Pille \& Vachard, 2011, thin section MA-RM37, Roc de Murviel, latest Viséan. • O - Cabrieroporellopsis inopinatus Pille \& Vachard, 2011, thin section DV-857(3), Japhet, late Viséan.

Tribe Borladelleae Vachard \& Cózar, 2011 trib. nov.

Diagnosis. - Vestibuled and articulated Diploporaceae, with acrophore and phloiophore laterals, and with articles moderately to strongly individualized (strongly prominent in the Borladellinae).

Composition. - Two subtribes: (1) Cabrieroporinae Pille \& Vachard, 2011; (2) Borladellinae Pille \& Vachard, 2011.
Remarks. - The centre of speciation of this tribe is very probably located in southern France and Spain, due its great genus differentiation in this area. However, this very poorly known and distributed tribe has possibly a larger geographical distribution, because a species was encountered as far as Alaska (Mamet \& Préat 2010), without any transitional area known between these two extremities. Until now in the Montagne Noire, the tribe included two endemic genera, Murvielipora Pille \& Vachard, 2011 (Fig. 8L) and Cabrieroporellopsis Pille \& Vachard, 2011 
(here Fig. 8G, N, O), but during this study, rare specimens of Borladella Cózar et al., 2007 have been found (Fig. 8M).

Occurrence. - Latest Viséan-Bashkirian; southern Spain, southern France, and Alaska.

Family ?Polyphysaceae Kützing, 1843

Tribe indet.

\section{Genus Neoradiosphaeroporella Cózar \& Vachard gen. nov.}

Type species. - Neoradiosphaeroporella aprica Cózar \& Vachard sp. nov.

Etymology. - Greek neo, new, because younger than $R a$ diospherella, similar genus.

Diagnosis. - Possible sporangia filled with spherical spores tangentially jointed together.

Composition. - Monospecific.

Comparison. - There are generally four interpretations of the groups of small spheres more or less linked by a microsparitic cement: 1) sporangia of Polyphysaceae (especially for the Mesozoic and Cenozoic forms); 2) calcification of the central cavity of endospore genera (e.g., Aciculella Pia, 1930 non 1927 and "Atractyliopsis" sensu Rich, 1974, Mamet \& Roux 1975a, and Devuyst 2006, non Pia 1937 ex Accordi, 1956), 3) vesicular dasycladales with large distal part and short proximal part (e.g., Holosporella Pia, 1930; Barrettiporella Granier \& Hofmann, 2002), 4) undeterminate groups of spherical bodies (e.g., Radiosphaeroporella Mamet \& Boulvain, 1992, Ningbingellina Mamet, 1998, Ningbingellina sensu Devuyst, 2006, figs 4.26.8-12, 23, Floritheca Gaillot \& Vachard, 2007, Aphanocapsites Maslov sensu Mamet \& Préat, 2013). Nevertheless, some of these groups of spheres do not belong to sporangia but to thallus of Epimastoporaceae (probably Palaepimastoporella); e.g., Atractyliopsis sp. sensu Mamet \& Rudloff, 1972, pl. 3, fig. 16 only (non pl. 3, figs 15, 17); Atractyliopsis sp. sensu Mamet, 1976, pl. 4, fig. 1; Atractyliopsis cumberlandensis Rich, 1974 sensu Skompski, 1986, pp. 259-260, pl. 2, figs 1, 6; and Coelosporella? sp. sensu Vachard \& Tahiri, 1991, pl. 4, fig. 19. On the other hand, some other "Atractyliopsis", or "Koninckopora" and "Coelosporella" (see Saltovskaya 1974, Berchenko 1981, Chuvashov et al. 1987, Brenckle \& Groves 1987, Mamet \& Préat 2010) most probably belong to a genus more or less related with Eokoninckopora Saltovskaya, 1984, which is neither an old Koninckopora (as etymologically suggested) nor even a dasycladale.
Remarks. - Usually, the isolated spheres of Neoradiosphaeroporella are covered by a thin layer of sparry calcite. The hollow of the uncalcified stem was only observed in three specimens (Fig. 9B, D, E), showing that the cortex seems to be composed of two rows of spheres. Some specimens show that the outer, thin layer of sparite is composed of a closer fibrous calcite rim (perhaps more resistant to recrystallization), growing in flat and polygonal sutures. The fibrous rims are usually preserved (probably calcitic in origin), but material between the rims is usually recrystallized, even micritized.

In Neoradiosphaeroporella, totally recrystallized cortices show a polygonal shape, and a different material can occur between the spherical rims and the rest of the cortex, that is easily recrystallized or micritized. Moreover, the arrangement of the spheres is more irregular, so oblique sections can show spheres of several diameters. The presence of two rows of spheres in Neoradiosphaeroporella is suggested in the oblique sections of more or less an entire thallus. Other facts that suggest the presence of this double row is the scarcity of sections in which the central hole is observed. The thickness of the microgranular and fibrous rims are always uniform around the spheres. However, small fragments of thallus usually show an irregular arrangement of the spheres and rarely alternate, coalescent rows of spheres. These fragments are interpreted as transverse sections of thallus, showing the two rows of spheres.

Occurrence. - The first unquestionable Polyphysaceae exist in the Serpukhovian of Tindouf (Cózar et al. 2014); consequently, Neoradiosphaeroporella gen. nov., which appears as early as the latest Viséan, is possibly a transitional stage to this family. However, B. Granier (pers. comm., May 2016) considers that Polyphysaceae did not exist during the Palaeozoic, and that this family only appeared in the Mesozoic. Neoradiosphaeroporella is currently only known in southern France and southern Spain.

\section{Neoradiosphaeroporella aprica Cózar \&} Vachard sp. nov.

Figure $9 \mathrm{~A}-\mathrm{G}$
v. 2007 cf. Radiosphaeroporella. - Cózar et al., p. 101, text-fig. 3.

?2010 Atractyliopsis lastensis Mamet \& Roux, 1978 (sic; in reality, this species was described by Pia 1937). Mamet \& Préat, pl. 3, figs 6, 7 (but numbered 7, 8 on the plate).

Etymology. - Latin apricus, sunny, because known from the most sunny areas of southern France and Spain.

Locus typicus. - Peñarroya 4 section, SW Spain (Cózar \& Rodríguez 1999a). 

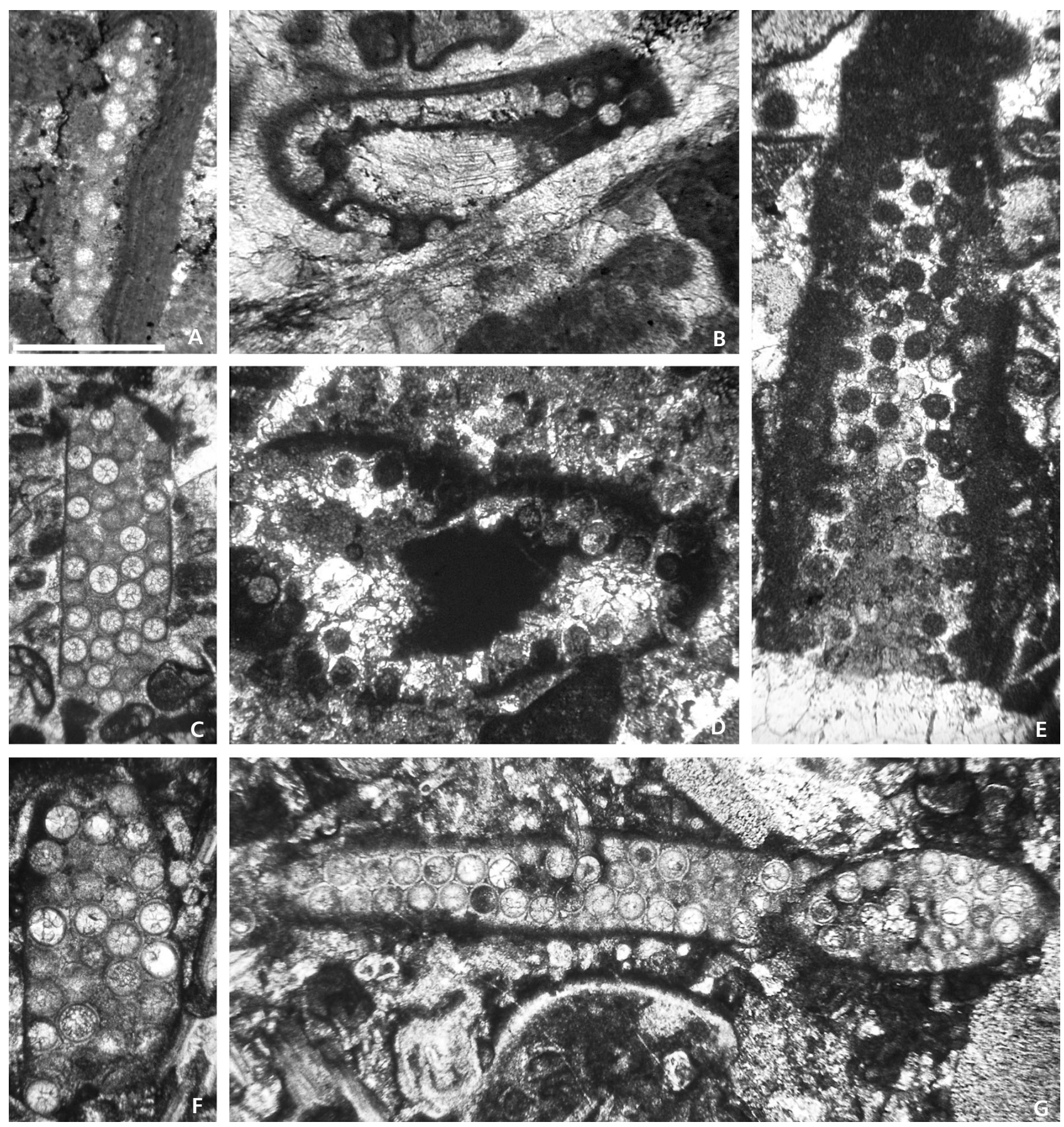

Figure 9. Neoradiosphaeroporella aprica gen. et sp. nov., late Viséan (scale bar $=0.5 \mathrm{~mm}$ ). A - thin section MA-RM6, Roc de Murviel. $\bullet$ B - thin section MA-RM9, Roc de Murviel. • C - paratype. Thin section Pc-SPL1/2e, Sierra Palacios. • D - thin section Pc-PÑR4/2b, Peñarroya 4. $\bullet$ E - holotype. Thin section Pc-PÑR4/2a, Peñarroya 4. • F, G - paratypes. Thin section Pc-SPL1/5c, Sierra Palacios.

Stratum typicum. - PÑR4/2a, near base of the level 2 in Peñarroya 4, early Asbian.

Holotype. - Fig. 9E, specimen DPM-Pc-PÑR4/2a.

Diagnosis. - Conical, elongate and irregular poorly to strongly calcified central cavity in which are located two ir- regularly arranged rows of calcified spheres (cysts?; endospore reproduction?). Contacts between the spheres with a differentiated wall, an inner microgranular layer, an intermediate fibrous rim of calcite, and outer fibrous calcite layer with flat and sharp coalescent sutures between the spheres. Wall generally dark-microgranular rarely recrystallized into neosparite. 
Description. - Only two specimens show slight oblique sections of the thallus, and most specimens are lateral sections or fragments of the cortex. Maximum length of the thallus is from $1.750 \mathrm{~mm}$ to $2.650 \mathrm{~mm}$, and the small fragments range from $0.500 \mathrm{~mm}$ to $1.700 \mathrm{~mm}$. The number of cysts in tangential section of the thallus is difficult to estimate. The inner diameter of the cysts varies, but it seems to depend on the orientation. In more homogenous sections, the cysts range from $0.070 \mathrm{~mm}$ to $0.120 \mathrm{~mm}$, the wall in the cortex is composed of three different layers: a thinner microgranular layer $(0.002-0.003 \mathrm{~mm})$, disposed around the cysts; a well preserved intermediate fibrous layer, covering the microgranular layer and with an uniform thickness around $(0.010-0.020 \mathrm{~mm})$; and an outer layer that may be recrystallized, micritized or rarely preserved as fibrous. In the latter case, the fibres have a coalescent growth, and the outer periphery of the cells are polygonalized. The outer surface of the cortex is slightly convex and regular; the inner surface of the cortex is strongly irregular and depends on the arrangement and size of the cysts in the internal row. No apertures have been observed in the cysts, but they seem to exist because many cysts have been preserved with micrite infilling (maybe as fine perforations crossing through the cortex). The cysts are rarely in alternate paired arrangements, and they usually show a slightly random arrangement.

Type material. - 28 oblique sections from southern Spain and three specimens from the Montagne Noire.

Repository of the types. - Department of Palaeontology (P. Cózar Ph.D. collection), Facultad de Ciencias Geológicas, Universidad Complutense de Madrid.

Comparison. - Differs from "Atractyliopsis" sensu Rich, 1974 and Mamet \& Roux 1975a and 1978 by shorter fragments and more regularly arranged, small, spherical cysts; from true Atractyliopsis (Pia, 1937) ex Accordi, 1956 emend. Praturlon, 1963 by a stronger calcification of the sporanges, and cysts more randomly arranged; from Acicu- lella Pia, 1930 non 1927 emend. Elliott, 1971 by the dark-microgranular calcification.

Occurrence. - Late Viséan of Roc de Murviel in the Montagne Noire (MA-RM6, MA-RM9) and of southwest Spain in Peñarroya 2 (Pc-PÑR2/2, Pc-528), Peñarroya 3 (Pc-PÑR3/2c), Peñarroya 4 (Pc-PÑR4/2a, Pc-PÑR4/2b) (Cózar \& Rodríguez 1999a), Sierra Palacios 1 (Pc-SPL1/2e, Pc-SPL1/5c) (Cózar \& Rodríguez 1999b), El Collado (Pc-817, Pc-825) (Cózar 2004) and Fuenteovejuna (Pc-1798) (Cózar et al. 2007).

Kingdom and phylum indeterminate

Class Algospongia Termier et al., 1977 ex Vachard \&

Cózar, 2010

Order Moravamminales Pokorny, 1951 ex Vachard in

Termier et al., 1975 nom. correct. herein; non Maslakova, 1990

Family Issinellaceae Deloffre, 1987 emend. Vachard \& Cózar, 2010 nom. correct. herein

\section{Genus Zidella Saltovskaya, 1984}

Type species. - Zidella maxima Saltovskaya, 1984.

Synonyms. - Einoriella (sensu Bogush et al. 1990, p. 107); Issinella (sensu Mamet \& Martínez 1981 and Mamet 1991 part.).

Diagnosis. - Cylindrical test, with external and internal surface irregularities and groups of blind, thin laterals linked in irregular rings within the skeleton. No diaphragms were observed (see Vachard 1991, fig. 2).

Composition. - Zidella maxima Saltovskaya, 1984; Uraloporella aurivella Vachard, 1977b.

Remarks. - Zidella was questionably assigned to the family Uraloporelleae by Shuysky (1985, p. 94). Herbig \& Mamet

Figure 10. Late Viséan-early Serpukhovian algospongia (scale bar $=0.5 \mathrm{~mm}$ ). $\bullet \mathrm{A}-$ Issinella sp., thin section MA-MN2, Les Mentaresses, latest Viséan. • B - Zidella aurivella (Vachard, 1977b), thin section DV-293f, Les lentilles de la route, late Viséan. • C - CrassikamaenalEvlania sp., thin section MA-RM34, Roc de Murviel, latest Viséan. • D - Exvotarisella index (Ehrenberg, 1854 sensu von Möller, 1879) Mamet \& Roux, 1974, thin section DV-601A, Les Pascales, early Serpukhovian. • E - Stacheoides polytrematoides (Brady, 1876), thin section MA-10-9, Castelsec, early Serpukhovian. -F - Costacheoides cannidahensis (Mamet \& Roux, 1983), thin section MA-10-12, Castelsec, early Serpukhovian. • G - Asphaltinella horowitzi Mamet \& Roux, 1978, thin section DV-FB4, Les lentilles de la route, late Viséan. • H - Claracrusta catenoides (Homann, 1972) Vachard, 1980, thin section MA-10-1, Castelsec, early Serpukhovian. •I - Sinustacheoides meandriformis (Mamet \& Rudloff, 1972) Termier et al., 1977, thin section MA-RM3, Roc de Murviel, latest Viséan. • J - Aoujgalia regularis Termier et al., 1977, thin section MA-RR7, Roque Redonde, latest Viséan. • K - Aoujgalia richi Mamet \& Roux, 1978, thin section MA-RR4, Roque Redonde, latest Viséan. • L - Valuzieria sescenti Termier et al., 1977 emend. herein, thin section MA-RM1, Roc de Murviel, latest Viséan. • M - Aoujgalia variabilis Termier \& Termier, 1950, thin section MA-10-1, Castelsec, early Serpukhovian. - N - Asteroaoujgalia gibshmanae Brenckle, 2004, thin section Pc-4622, Les Pascales, early Serpukhovian. • O - Kamaenella denbighi Mamet \& Roux, 1974, thin section DV-137f, Roc de Loup-Vailhan, late Viséan. • P - Aoujgalia skimoensis (Mamet \& Rudloff, 1972), thin section Pc-4445, Roque Redonde, latest Viséan. $\bullet$ Q - Roquesselsia cf. radians Termier et al., 1977, thin section MA-10-17, Castelsec, early Serpukhovian. • R - Palaeoberesella lahusenii (Möller, 1879) Mamet \& Roux, 1974, thin section MA-10-12, Castelsec, early Serpukhovian. • S - Roquesselsia radians Termier et al., 1977, thin section MA-10-7, Castelsec, early Serpukhovian. 

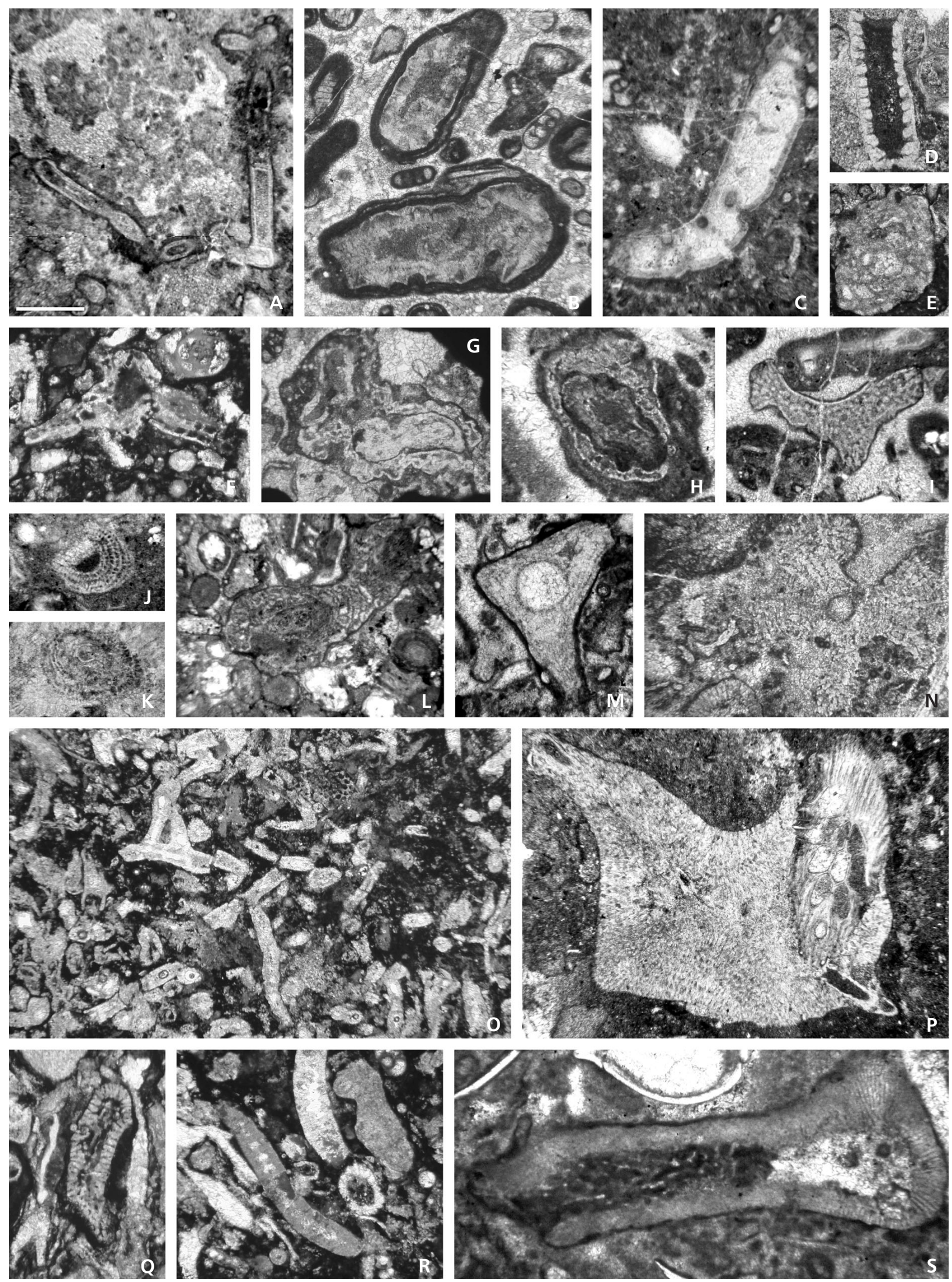

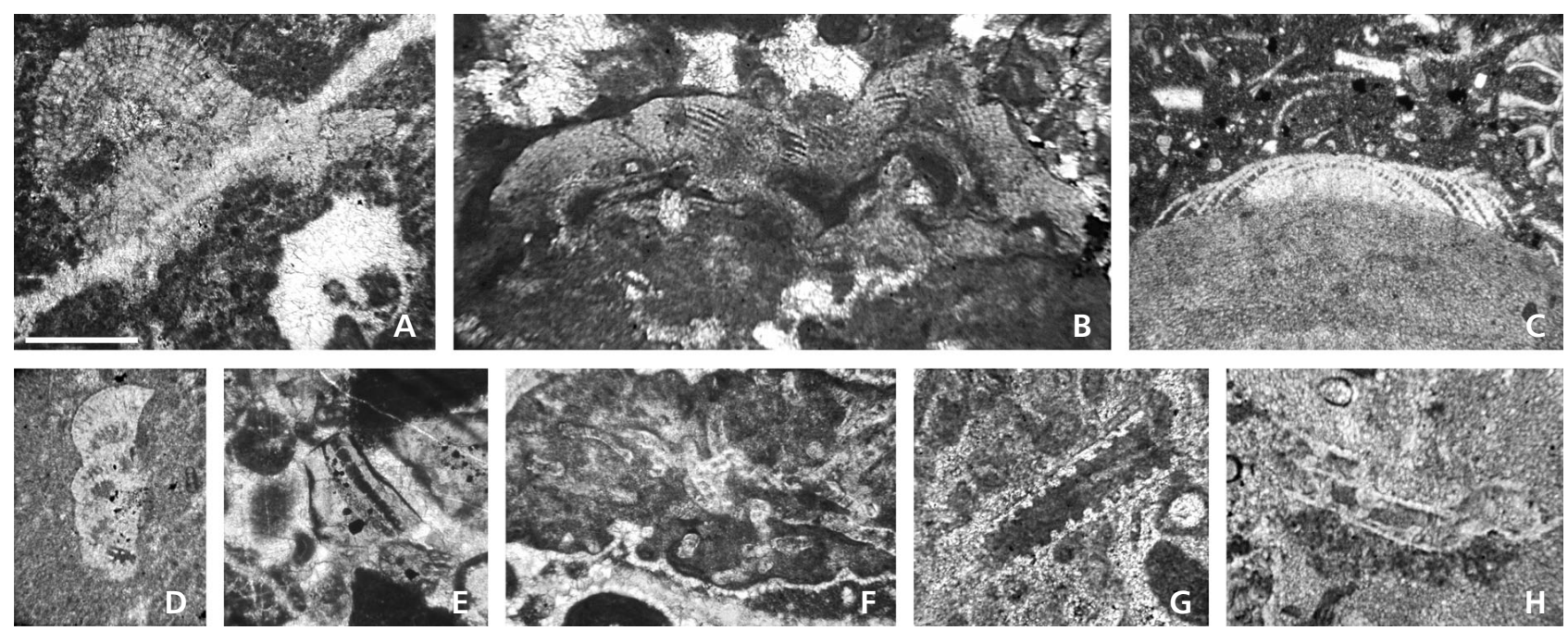

Figure 11. Late Viséan-early Serpukhovian algospongia (scale bar $=0.5 \mathrm{~mm}$ ). A - Fourstonella irregularis Mamet \& Roux, 1977, thin section DV-248B, Roc de Loup-Vailhan, late Viséan. • B - Fourstonella densifolia (Vachard in Vachard \& Montenat, 1981) ex Vachard \& Cózar, 2010, thin section MA-10-14(2), Castelsec, early Serpukhovian. • C - Fourstonella johnsoni (Flügel, 1966) ex Vachard \& Cózar, 2010, thin section Pc-4447, Roque Redonde, latest Viséan. • D - Stacheia marginuloides Brady, 1876, thin section MA-RM49, Roc de Murviel, latest Viséan. $\bullet$ E - Fasciella scalaeformis Vachard et al., 2004, thin section DV-431, Mounio, late Viséan. • F - Kamaenella? sp., thin section DV-848, Les lentilles de la route, late Viséan. - G - Kamaena? sp., thin section DV-12-26, Roc du Cayla, latest Viséan. • H - kamaenacean transitional form to the beresellaceans, thin section MA-RM11, Roc de Murviel, early Serpukhovian.

(1994, text-fig. 4, p. 101) considered "Luteotubus, Zidella, etc." (sic) as synonyms of Issinella grandis Chuvashov, 1965. However, this latter species, which is a true Issinella as recently redescribed by Okuyucu et al. (2013) (i.e., a tube with any irregularities, and randomly arranged laterals), entirely differs from Luteotubulus (the exact spelling of this taxon) and Zidella (see remarks in Vachard 1993). Nevertheless, we admit that Zidella minor Ivanova, 1988 could be an Issinella.

Occurrence. - Late Viséan of Tien-Shan, Tajikistan (Saltovskaya 1984), central and southern Urals (e.g., Ivanova 1988, Bogush et al. 1990, Ivanova \& Bogush 1992), South China (Mamet \& Préat 2013), Sumatra (Vachard 1989), central Morocco (Berkhli 1999, p. 108), Spain and Ireland (Vachard \& Cózar 2010). Venevian (rather common) to Steshevian (rare) in the Montagne Noire (Pille 2008 re-interpreted and this study).

\section{Zidella aurivella (Vachard, 1977b) emend. herein} Figure 10B

v. 1974b Uraloporella cf. sieswerdai Racz. - Vachard, p. 182, pl. 8, figs 2, 3 .

v. 1977a Uraloporella aurivella Vachard. - Vachard, p. 374, table 1 (no illustration) (nomen nudum).

v. 1977b Uraloporella aurivella Vachard, p. 133, pl. 1, fig. 11 (with one reference in synonymy).

?1981 Issinella devonica Reitlinger. - Mamet \& Martínez, pl. 2, figs 2, 3 (or another species of Zidella).
1990 Einoriella elongata Saltovskaya. - Bogush et al., p. 107, pl. 11, fig. 11.

v. 1991 Zidella aurivella (Vachard). - Ouarache et al., pp. 51-52 (no illustration).

1995 Issinella licis (Malakhova). - Sánchez-Chico et al., pl. 1, fig. 7-5.

v. 1998 Zidella aurivella (Vachard) n. comb. - Delvolvé et al., p. 366 (no illustration).

v. 2002 Zidella aurivella (Vachard). - Berkhli \& Vachard, p. 69 (no illustration).

2008 Zidella aurivella (Vachard). - Pille, p. 65, pl. 21, figs $9-17$.

2010 Zidella aurivella Vachard (sic: no parentheses). Vachard \& Cózar, p. 165, pl. 3, figs 4-6.

?2013 Zidella? shangsiensis Mamet \& Préat, p. 41, pl. 6 i.

Description. - This large species is especially well represented in the Lenses of the road, near Roquessels (Lentilles de la route), but rare specimens exist also in Roquemaillère and Roc de Murviel. Length $=0.420-1.640 \mathrm{~mm}$, outer diameter $=0.270-0.590 \mathrm{~mm}$, inner diameter $=0.100-0.370 \mathrm{~mm}$; wall thickness $=0.085-0.110 \mathrm{~mm}$.

Remarks. - Zidella aurivella differs from Z. maxima in smaller dimensions, and from Z. minor Ivanova, 1988, in its larger parameters. Zidella? shangsiensis Mamet \& Préat, 2013, which unquestionably belongs to Zidella, has the same profile and outer diameter $(0.400-0.500 \mathrm{~mm})$ as Zidella aurivella; however, this taxon is too poorly 

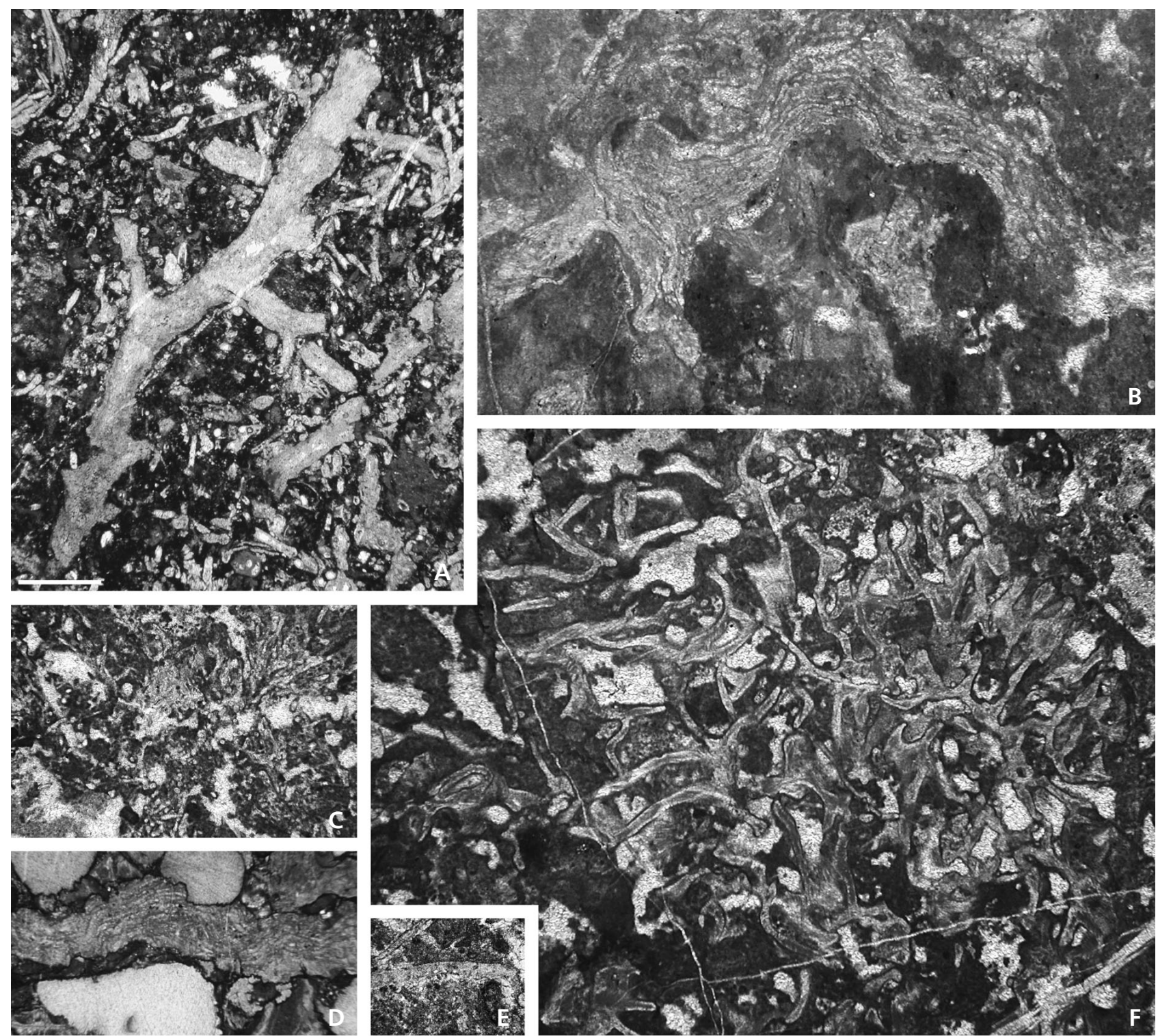

西
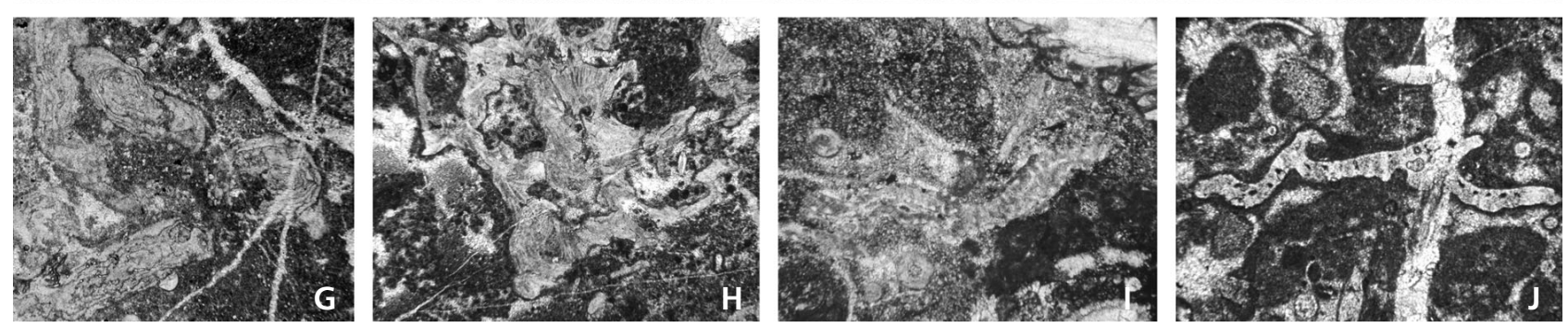

Figure 12. Late Viséan-early Serpukhovian Calcifoliina (scale bar $=1 \mathrm{~mm}$ except for figures $\mathrm{E}$, $\mathrm{I}$ and $\mathrm{J}=0.5 \mathrm{~mm}$ ). $\bullet \mathrm{A}-$ Ungdarella uralica Maslov 1950, thin section DV-137f, Roc de Loup-Vailhan, late Viséan. • B - Fasciella crustosa Vachard et al., 2004, thin section MA-25-16, La Boutinelle, late Viséan. • C - Praedonezella primitiva Vachard et al., 2004, thin section MA-LS Feldweg 17, La Serre-vineyard, early Serpukhovian. •D - Fascifolium pantherium Vachard \& Cózar, 2010, thin section MA-SP18, La Serre de Péret, early Serpukhovian. • E - Calcifolium okense Shvetsov \& Birina, 1935 , thin section Pc-4590, Roc du Cayla, latest Viséan. • F - Falsocalcifolium punctatum (Maslov, 1956), thin section MA-LS Feldweg 58, La Serre-vineyard, early Serpukhovian. • G - Fasciella kizilia Ivanova, 1973, thin section DV-620, Japhet, late Viséan. • H - Falsocalcifolium punctatum (Maslov, 1956), thin section Pc-4540, Castelsec, early Serpukhovian. • I - Falsocalcifolium punctatum (Maslov, 1956), thin section DV-687a, Les Mentaresses, latest Viséan. • J - Calcifolium okense Shvetsov \& Birina, 1935, thin section Pc-4593, Roc du Cayla, latest Viséan. 
illustrated to definitively conclude that it is a junior synonym of this latter species.

The taxon Einoriella elongata sensu Bogush et al. (1990, p. 107, pl. 11, fig. 11; non Saltovskaya, 1984) possesses the same dimensions as Zidella aurivella. Nevertheless, as the true E. elongata more resemble species of Donezella, we assign herein the misinterpreted taxon of Bogush et al. (1990) to Zidella aurivella.

Occurrence. - Late Viséan of Tien-Shan, central and southern Urals, South China and Sumatra. Late or latest Asbian? of central Morocco and South China (Shangsi Fm). Questionable in Spain. Venevian (relatively common) to Tarusian-Steshevian (rare) in the Montagne Noire: Lenses of the road (DV293D, DV293E including the holotype, DV293F, DV293G, DV293H, DV293.2.C, DV332'A, DVFB4; see Vachard \& Cózar 2010, pl. 3, figs 4, 6); sommet 224-Valuzières (DV600B, see Vachard \& Cózar 2010, pl. 3, fig. 5); Roquemaillère (DV134F, DV134G); and Roc de Murviel (MA82, MA83).

Order Aoujgaliales Termier et al., 1975 ex Vachard \& Cózar, 2010 nom. correct. herein

Suborder Aoujgaliina Termier et al., 1975 nom. translat. Vachard \& Cózar, 2010

Family Aoujgaliaceae Termier et al., 1975 nom. correct. Brenckle, 1977

Tribe Aoujgaliae Termier et al., 1975 nomen translat. Chuvashov in Chuvashov et al., 1987

\section{Genus Valuzieria Termier et al., 1977 emend. herein}

Type species. - Valuzieria sescenti Termier et al., 1977.

Diagnosis. - Similar to Aoujgalia Termier \& Termier, 1950 , but with turriform expansions, and an alignment of the lateral walls of the cells.

Remarks. - Created as a distinct genus by Termier et al. (1977), Valuzieria was synonymized with Aoujgalia by Vachard \& Cózar (2010). However, our new material proved that Valuzieria is transitional between Aoujgalia and Asteroaougalia, and not really synonymous of one or each other of both genera. Consequently, we re-describe here Valuzieria as a valid genus and we indicate its differences with the two genera. Even if rare arms are common among the aoujgaliaceans (see e.g., Krings et al. 1987, pl. 5, fig. 3; Brenckle \& Marchant 1987, pl. 5, fig. 3; Vachard \& Cózar 2010, pl. 9, figs 13,18$)$, they are first really developed in Valuzieria, which anunciates the numerous arms of Asteroaoujgalia.

Occurrence. - Early-late Brigantian of the Montagne Noire and central Morocco.
Valuzieria sescenti Termier et al., 1977 Figure 10L

p. 1974 Stacheoides. - Rich, pl. 4, fig. 21 (non pp. 371-372, nec pl. 4, figs 1-5 = true Stacheoides).

v. 1977 Valuzieria sescenti Termier et al., pp. 154-155, pl. 6, fig. 1 .

v. 1977a Valuzieria sescenti Termier \& Vachard (sic). Vachard, p. 374, table 1 (no illustration).

? 1983 Stacheoides sp. - Vieslet, pl. 5, fig. 4.

? v. 1991 Valuzieria sp. - Ouarache et al., pp. 50, 52 (no illustration).

v. non 1991 Valuzieria sescenti Termier, Termier \& Vachard. Vachard et al., pl. 1, fig. 7 (most probably Stacheoides).

v. 1999 Valuzieria sp. - Berkhli, p. 111 (no illustration).

v. 2008 Valuzieria sescenti G. Termier et al. - Pille, p. 84, pl. 27, figs 1-5.

v. 2010 Aoujgalia (= Valuzieria) sescenti G. Termier et al. - Vachard \& Cózar, p. 194, pl. 9, figs 1-5.

Description. - The holotype was defined in the sample DV600B of sommet 224-Valuzières. Maximal dimension of thalllus $=2.000 \mathrm{~mm}$, thickness of skeletal elements $=$ $0.020-0.050 \mathrm{~mm}$, dimensions of cells $=0.050-0.070 \mathrm{~mm}$.

Occurrence. - This form remains very rare in the type locality, sommet 224-Valuzières, in DV600A (two specimens) and DV600B (two specimens). Four other specimens were discovered in Roc de Murviel (MA-83) and Les Jeantels (DV690C) by Pille (2008). A new specimen from Roc de Murviel (MA-RM1) is illustrated herein. Representative specimens of the transition to Asteroaoujgalia have been discovered in central Morocco (Tizra 2 and Mouarhaz sections) by Vachard \& Cózar (2010); they are presumably present in the Montagne Noire.

\section{Genus Asteroaoujgalia Brenckle, 2004 emend. herein}

Type species. - Asteroaoujgalia gibshmanae Brenckle, 2004.

Emended diagnosis. - Aoujgaliidae with concentric rows of quadratic chamberlets and numerous turriform expansions.

Composition. - Monospecific.

Remarks. - Asteroaoujgalia, although assigned with doubt to the Aoujgaliaceae by Brenckle (2004), unquestionably belongs to this family. It is relatively similar to Aoujgalia and Valuzieria but differs from these two genera by its more numerous turriform expansions and its pillars less 
Figure 13. Stratigraphic distribution of the algae and algospongia in the Calcaires à Productus in the Montagne Noire. In the upper part are situated the correlations of the studied stratigraphic sections and foraminiferal biozones described in Vachard et al. (in press).
La Serre de Péret

La Serre

Castelsec North

Les Pascales East

Castelsec South

Château-Vailhan East Roque Redonde Les Jeantels

Roquemaillère

Les Pascales West

Roc de Murviel

Roc de Loup-Vailhan

Château-Vailhan West

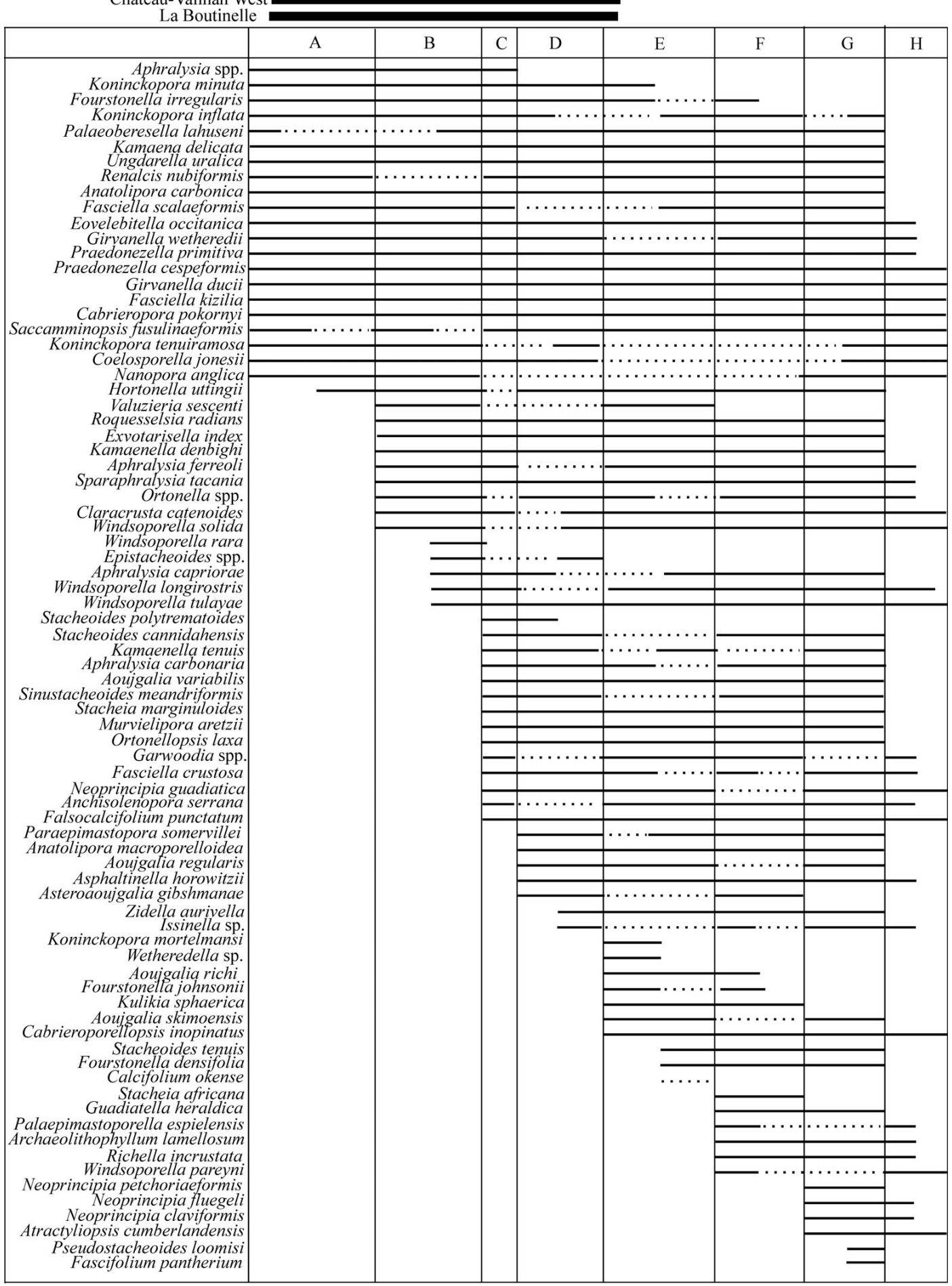


regularly and vertically aligned; nevertheless, intermediate cases exist, see e.g., the specimens illustrated by Brenckle 2004, pl. 8, fig. 5 (left, bottom).

Occurrence. - Late Viséan of Tarim (China) and Serpukhovian of Precaspian Basin (Kazakhstan) (Brenckle 2004). Late Brigantian of Boulonnais, northern France (D.V. unpublished data). Discovered in the early Serpukhovian of the Montagne Noire.

\section{Asteroaoujgalia gibshmanae Brenckle, 2004}

Figure 10N

2004 Asteroaoujgalia gibshmanae Brenckle, pp. 159, 161, pl. 7, fig. 1, pl. 8, figs 1-7.

2010 Asteroaoujgalia gibshmanae Brenckle. - Vachard \& Cózar, p. 192 (no illustration).

Description - Maximal dimension of thalllus $=2.160 \mathrm{~mm} \times$ $1.530 \mathrm{~mm}$, thickness of skeletal elements $=0.030-0.060 \mathrm{~mm}$, dimensions of cells $=0.075-0.080 \mathrm{~mm}$.

Occurrence. - As for the genus.

\section{Discussion}

It has long been recognized that several cyanobacteria, algae and algosponges are limited to the Mississippian and/or Pennsylvanian (e.g., Garwood 1914; Wood 1940, 1942, 1963, 1964; Johnson \& Konishi 1956; Maslov 1956; Elliott 1968a; Petryk \& Mamet 1972; Emberger 1976; Vachard \& Cózar 2010) and the importance of some algae and algosponges at least as regional biostratigraphic markers has been clearly demonstrated (e.g., Mamet \& Rudloff 1972; Vachard 1977a, b; Perret \& Vachard 1977; Skompski 1981, 1986, 1987; Mamet \& Roux 1983; Skompski et al. 1989; Mamet 1991, 1997, 2002, 2006; Vachard \& Berkhli 1992; Sebbar \& Mamet 1996, 1999; Mamet et al. 1996; Sebbar 1998; Berkhli \& Vachard 2001; Krainer \& Vachard 2002; Cózar 2004, 2005; Cózar \& Somerville 2004, 2005a-c; Cózar et al. 2008, 2009; Pille 2008; Somerville 2008; Pille \& Vachard 2011). Several genera first appear and diversify in the late Viséan and Serpukhovian; e.g., Ungdarella, Kulikia, Neoprincipia, Richella, Archaeolithophyllum, Falsocalcifolium and Calcifolium (see Burgess 1965, Termier et al. 1975, Conil et al. 1980, Mamet et al. 1980, Cózar \& Vachard 2003, Vachard \& Cózar 2005, Cózar \& Somerville 2005a, b, Pille 2008, Somerville 2008).

The detailed stratigraphic distribution (Fig. 13) of the algal taxa identified in various outcrops of the "calcaires à Productus", not only enable to confirm the regional biozones based on foraminiferal assemblages (Vachard et $a l$, in press), but also helps to identify finer stratigraphic intervals.

(a) Fourstonella irregularis Mamet \& Roux, 1977, Anatolipora carbonica, Fasciella scalaeformis Vachard et al., 2004, Eovelebitella occitanica Vachard, 1974a, Cabrieropora pokornyi Mamet \& Roux, 1975a, Saccamminopsis fusulinaeformis (McCoy, 1849), Coelosporella jonesii Wood, 1940, Praedonezella primitiva Vachard et al., 2004, and P. cespeformis (Kulik, 1973) are recorded from the late Viséan biozone A.

(b) The different species of Aphralysia are common in the late-latest Viséan biozones A, B and C.

(c) Koninckopora spp., present in late-latest Viséan biozones A to D, are rare in latest Viséan-Serpukhovian biozones E to H. Koninckopora mortelmansi is regionally limited to the latest Viséan biozones D-E and early Serpukhovian F-H.

(d) Valuzeria sescenti is restricted to the late-latest Viséan biozones B-E.

(e) Sparaphralysia is known from the late Viséan to Serpukhovian biozones B to $\mathrm{H}$.

(f) The FO of Claracrusta is located at the base of the late Viséan biozone B. That is probably also the FAD of this taxon based on the data of the literature.

(g) The late Viséan biozone B is characterized by the presence of different species of Windsoporella. W. rara is limited to the uppermost Mikhailovian (upper B).

(h) The latest Viséan biozone $\mathrm{C}$ is characterized by the FOs of Murvielipora, Ortonellopsis, Fasciella crustosa Vachard et al., 2004, Neoprincipia guadiatica Cózar \& Vachard, 2003, Anchisolenopora serrana, and Falsocalcifolium punctatum (Maslov, 1956).

(i) In latest Viséan biozone D, the FOs of Anatolipora macroporelloidea sp. nov., Paraepimastopora somervillei sp. nov., Zidella aurivella, and Asteroaoujgalia gibshmanae are recorded.

(j) The latest Viséan biozone E is principally characterized by the FOs of Kulikia sphaerica, Cabrieroporellopsis inopinatus, and various atypical Fourstonella spp. (F. johnsoni and F. chuvashovia).

(k) The early Serpukhovian biozone F is principally characterized by the FOs of Archaeolithophyllum lamellosum Wray, 1964 and Richella incrustata.

(1) The early Serpukhovian biozone G is characterized by the FOs of three small species of Neoprincipia: $N$. petschoriaeformis, N. fluegeli, and N. claviformis.

(m) Currently, no algal markers characterize the late Serpukhovian biozone $\mathrm{H}$.

Compared to other European areas, the cyanobacteria Aphralysia might be of higher biostratigraphic value in the Viséan-Serpukhovian boundary interval of the Montagne Noire, due its abundance and the numerous cited species. However, thorough taxonomical and biostratigraphical 
studies of this genus are needed in other regions in order to evaluated its biostratigraphical potential for interregional correlation.

The distribution of Saccamminopsis in England is late-latest Viséan, Aleksinian-Venevian (Hawes-Three Yard; Hallett 1971), whereas it is late Viséan to early Serpukhovian, Mikhailovian-Steshevian in the Montagne Noire.

Koninckopora is a well-known problematic dasyclad with a cosmopolitan distribution, which was long time considered as restricted to the middle-late Viséan around the world (e.g., Termier et al. 1975, Vachard \& Berkhli 1992, Berkhli \& Vachard 2001, Pille 2008). However, in recent years, several discoveries in the Serpukhovian have been mentioned Koninckopora in China (Mamet 1991, Groves et al. 2012), SW Spain (Cózar 2005) and the Moroccan Meseta (Cózar et al. 2008). In the Montagne Noire, different species of Koninckopora also exist in the early Serpukhovian (biozones F-H). Furthermore, a unquestionable late Serpukhovian occurrence of Koninckopora has been documented in the Tindouf Basin (Cózar et al. 2014).

Coelosporella was known to appear in the late Viséan in England, southern France and eastern Morocco (Hallett 1971, Vachard 1977b, Vachard \& Berkhli 1992, Pille 2008). It has been documented up to the late Serpukhovian in SW Spain (Cózar 2005), and it is present in the Bashkirian of the western Moroccan Meseta (Cózar et al. 2011). In the Montagne Noire, the genus is present in all late Viséan to Serpukhovian biozones A to $\mathrm{H}$ (i.e., from Mikhailovian to Steshevian).

Another long-ranged taxon in the Montagne Noire is Nanopora. However, this long-range is not surprising because this genus also subsists up to the late Serpukhovian in the Pyrénées (Perret \& Vachard 1977, Pille 2008), SW Spain (Cózar 2005) and Western Moroccan Meseta (Cózar et al. 2011), and even reaches into the Bashkirian in the Tindouf Basin (Cózar et al. 2014).

Possible polyphysacean dasycladales, with Neoradiosphaeroporella gen. nov., appear in the biozones G-H of the late? early Serpukhovian in the Montagne Noire; "Atractyliopsis" (but probably to re-name) appears in the early Serpukhovian in the Tindouf Basin (Cózar et al. 2014) and the Béchar Basin (Sebbar \& Mamet 1996), and in the late Serpukhovian of the Western Moroccan Meseta (Cózar et al. 2011). In Tindouf, a new species of the same false-"Atractyliopsis" is then characteristic of the latest Serpukhovian to Bashkirian interval. In the Montagne Noire, possible polyphysaceans Neoradiosphaeroporella gen. nov. appear almost coevally; i.e., in the biozone $\mathrm{G}$ of the late early Serpukhovian.

Zidella is a Mikhailovian genus of Tajikistan, South China and Sumatra (Vachard \& Cózar 2010), also known in the Serpukhovian of Tindouf (Cózar et al. 2014). In the Montagne Noire, Zidella is present from B to G; therefore, it appears to be characteristic for the Viséan-Serpukhovian boundary interval identified in this study.

Calcifolium okense is rare in lower Venevian (Five Yard), common in the upper Venevian (Three Yard)-Tarusian (Underset) in northern England (Hallett 1971). In the Montagne Noire, this species is extremely rare and localized in rocks assigned to the early Serpukhovian biozone F.

\section{Conclusions}

1. The "calcaires à Productus" of the southern Montagne Noire contains rich cyanobacterial and algal microfloras which are taxonomically and biostratigraphically revised herein.

2. The cyanobacteria are generically well known. The particularities of the assemblages are the diversity of the genera Renalcis and Aphralysia. A new genus Ortonellopsis gen. nov. displays a very loose organisation of its network of trichomes.

The rare red algae also were relatively well known, especially the species of Neoprincipia and Archaeolithophyllum. A new genus is described, Anchisolenopora gen. nov., which might justify a transition at least morphological between cyanobacteria and red algae.

Among the green algae, the true dasycladales recently redescribed, and the regionally rare Koninckopora, are not rediscussed herein; except for Paraepimastopora somervillei $\mathrm{sp}$. nov. in order to indicate an accurate dating of the appearance of the epimastoporacean lineages. The regionally abundant group of uncommon metaspondyl dasycladales, Borlatelleae trib. nov., is analyzed as well as Neoradiosphaeroporella aprica gen. et sp. nov., which is possibly the first real representative of the very specialized group of the polyphysacean dasycladales.

3. The group of the Anatoliporaceae is revised, also due to its regional importance, and hypothetically assigned to the ulotrichales. The new taxon Anatolipora macroporelloidea sp. nov. is described.

4. About the incertae sedis aoujgaliales, only new informations are provided on Zidella, often common in the "calcaires à Productus", as well as on rare Valuzieria and Asteroaoujgalia. Phylogenetically, these two latter genera appear very closely related.

5. The detailed stratigraphic distribution of the cyanobacterial and algal taxa enables to refine and better characterize the recently defined regional biozones $\mathrm{A}$ to $\mathrm{H}$ based on foraminiferal assemblages. The distribution of algae help to identify finer stratigraphic intervals. 
(a) The late Viséan biozone A (early Mikhailovian) is characterized by Fourstonella irregularis, Anatolipora carbonica, Fasciella scalaeformis, Eovelebitella occitanica, Cabrieropora pokornyi, Saccamminopsis fusulinaeformis, Coelosporella jonesii, Praedonezella primitiva, and P. cespeformis.

(b) The late Viséan biozone B (late Mikhailovian) is typified by different species of Windsoporella; among them, W. solida is limited to the latest Mikhailovian (upper B).

(c) The latest Viséan biozone C (early Venevian) is identified by the FOs of Murvielipora, Ortonellopsis gen. nov., Fasciella crustosa, Neoprincipia guadiatica, Anchisolenopora serrana, and Falsocalcifolium punctatum.

(d) In latest Viséan biozone D, the FOs of Asteroaoujgalia gibshmanae, Zidella aurivella, and Anatolipora macroporelloidea are recorded.

(e) The late Viséan biozone E is principally marked by the FOs of Kulikia sphaerica, Cabrieroporellopsis inopinatus, and various atypical Fourstonella spp. (like $F$. johnsoni and $F$. chuvashovia).

(f) The early Serpukhovian biozone F is based on the FOs of Archaeolithophyllum lamellosum and Richella incrustata.

(g) The early Serpukhovian biozone $\mathrm{G}$ is characterized by three small species of Neoprincipia: N. petschoriaeformis, $N$. fluegeli, and $N$. claviformis and by the possible first polyphysaceans Neosphaeroporella aprica gen. et sp. nov.

(h) Currently, no algal markers have been found in the foraminiferal late Serpukhovian biozone $\mathrm{H}$.

6. The algal microflora of the Montagne Noire contains numerous biostratigraphical markers in the Viséan-Serpukhovian boundary interval, and might help to foster the stratigraphic framework of this interval.

\section{Acknowledgements}

Field work of D.V. and P.C. was funded by the Spanish Ministerio de Economía y Competitividad (research project CGL2012-30922BTE). Thanks to B. Granier and J. Kalvoda for their constructive reviews.

\section{References}

ACCORDI, B. 1956. Calcareous algae from the Upper Permian of the Dolomites (Italy), with stratigraphy of the "Bellerophon-zone". Journal of the Palaeontological Society of India 1(1), 75-84.

ANTROPOv, I.A. 1950. New foraminiferal species of the Late Devonian of some areas of the eastern Russian Platform. Akademiya nauk SSSR, Izvestiya Kazanskogo filiala, Geologicheskiy institut 1, 21-33. [in Russian]
Antropov, I.A. 1955. Blue green algae from the Devonian of the central areas of the eastern Russian Platform. Uchenye zapiski Kazanskogo gosudarstvennogo universiteta imeni V.I. Ulyanova-Lenina, Trudy Obshchestva estestvoispytatelei 115(8), 41-53. [in Russian]

Antropov, I.A. 1967. Devonian and Lower Carboniferous (Tournaisian) algae of the central part of the eastern Russian Platform. Akademiya nauk SSSR, Sibirskoye otdeleniye, Institut geologii i geofiziki, Trudy, 118-125. [in Russian]

Aretz, M. 2002. Habitatanalyse und Riffbildungspotential kolonialer rugoser Korallen im Unterkarbon (Mississippium) von Westeuropa. Kölner Forum für Geologie und Paläontologie, Geologisches Institut der Universität zu Köln 10, 1-155.

Aretz, M. 2016. The Kulm Facies of the Montagne Noire (Mississippian, southern France). Geologica Belgica 19(1-2). DOI 10.20341/gb.2015.018

Barattolo, F., De Castro, P. \& Parente, M. 1993. Some remarks on Griphoporella curvata (Gümbel 1872) Pia 1915, dasycladacean alga from the upper Triassic, 23-45. In Barattolo, F., De Castro, P. \& Parente, M. (eds) Studies on fossil benthic algae. Bollettino della Società Paleontologica Italiana, special volume 1.

Bassoullet, J.P., Bernier, P., Deloffre, R., GÉnot, P., JafFrezo, M. \& VACHARD, D. 1979. Essai de classification des Dasycladales en tribus. Bulletin des Centres Recherche Exploration-Production Elf-Aquitaine 3(2), 429-442.

Berchenko, O.I. 1981. Calcareous algae from Tournaisian deposits of Donbass. 72 pp. Naukova dumka, Kiev. [in Russian]

BERKHLI, M. 1999. Sédimentologie, biostratigraphie et stratigraphie séquentielle du Nord-Est de la Méséta occidentale marocaine pendant le Carbonifère inférieur (Viséen-Serpoukhovien). 229 pp. Thèse de Doctorat d'État ès Sciences, Université Moulay Ismail Meknès 20 (unpublished).

BERKhLI, M. \& VACHARD, D. 2001. New biostratigraphical data from the Early Carboniferous sequences of the Adarouch area (NE Central Morocco). Newsletter on Stratigraphy 39(1), 33-54.

BerkhLi, M. \& VACHARD, D. 2002. Le Carbonifère du Maroc central: les formations de Migoumess, de Tirhela et d'Idmarrach. Lithologie, biostratigraphie et conséquences géodynamiques. Comptes Rendus de l'Académie des Sciences 334, 67-72. DOI 10.1016/S1631-0713(02)01699-1

Bessey, C.E. 1907. A synopsis of plant phyla. University Studies of the University of Nebraska 7, 275-373.

Bogush, O.I., Ivanova, R.M. \& Luchinina, V.A. 1990. Calcareous algae from the late Famennian and Early Carboniferous of Urals and Siberia. Akademiya nauk SSSR, Sibirskoe otdelenie, Trudy instituta geologii i geofiziki 745, 1-160. [in Russian]

BöHM, R. 1935. Étude sur les faunes du Dévonien supérieur et Carbonifère de la Montagne Noire. Thèse doctorat, Université de Montpellier, Imprimerie de la Charité, Montpellier.

Bourque, P.A., MAmet, B. \& Roux, A. 1981. Algues siluriennes du synclinorium de la Baie des Chaleurs. Québec, Canada. Revue de Micropaléontologie 24(2), 83-126.

BorzI, A. 1895. Studi algologici: saggio di richerche sulla biologia delle alghe 2.378 pp. G. Capra, Palermo.

Brady, H.B. 1876. A monograph of Carboniferous and Permian foraminifera (the genus Fusulina excepted). Palaeontographical Society of London 30, 1-166.

BRENCKLE, P. 1977. Mametella, a new genus of calcareous red al- 
gae (?) of Mississippian age in North America. Journal of Paleontology 51(2), 250-255.

BrenCKLE, P.L. 1985. Cribrokamaena and Crassikamaena, new genera of Late Paleozoic algae from the United States. Micropaleontology 31(1), 55-67. DOI 10.2307/1485580

Brenckle, P.L. 2004. Late Visean (Mississippian) calcareous microfossils from the Tarim Basin of western China. Journal of Foraminiferal Research 34, 144-164. DOI 10.2113/0340144

BRENCKLE, P.L. \& Groves, J.R. 1987. Calcareous foraminifers from the Humbolt Oolite of Iowa: Key to early Osagean (Mississippian) correlations between eastern and western North America. Palaios 1(1986), 561-581. DOI 10.2307/3514707

Brenckle, P.L. \& Marchant, T.R. 1987. Calcareous microfossils, depositional environments and correlation of the Lower Carboniferous Um Bogma Formation at Gebel Nukul, Sinai, Egypt. Journal of Foraminiferal Research 17(1), 74-91. DOI 10.2113/gsjfr.17.1.74

BRooke, C. \& Riding, R. 1998. Ordovician and Silurian coralline red algae. Lethaia 31, 185-195. DOI 10.1111/j.1502-3931.1998.tb00506.x

Brooke, C. \& Riding, R. 2000. Graticula and its derivatives, replacement name for the alga Craticula Brooke and Riding non-Grunow. Lethaia 33, 82. DOI 10.1080/00241160050150203

Brune, R.V. \& Moore, L.S. 1987. Microbialites: organosedimentary deposits of benthic microbial communities. Palaios 2, 241-254. DOI 10.2307/3514674

Buchroithner, M., Flügel, E., Flügel, H. \& Stattegger, K. 1980. Mikrofazies, Fossilien und Herkunft der Kalk-Gerölle im Karbon-"Flysch" der Betischen Kordilleren, Spanien. Facies 2, 1-54. DOI 10.1007/BF02536462

BuRgEss, I. C. 1965. Calcifolium (Codiaceae) from the Upper Visean of Scotland. Palaeontology 8(1), 192-198.

Bүкоva, E.V. 1952. Devonian foraminifers from Russian Platform and Preurals. Trudy VNIGRI 60, Microfauna USSR 5, 5-64. [in Russian]

Cartwright, N.G., Gooday, A.J. \& Jones, A.R. 1989. The morphology, internal organization, and taxonomic position of Rhizammina algaeformis Brady, a large, agglutinated, deep-sea foraminifer. Journal of Foraminiferal Research 19(2), 115-125. DOI 10.2113/gsjfr.19.2.115

Cavalier-Smith, T. 2002. The phagotrophic origin of eukaryotes and phylogenetic classification of Protozoa. International Journal of Systematic and Evolutionary Microbiology 52, 297-354. DOI 10.1099/00207713-52-2-297

Chanton-Güvenç, N. 1972a. Présence d'algues calcaires dans le Carbonifère marocain. Bulletin de la Société géologique de France, $7^{e}$ série 13, 187-194.

Chanton-Güvenç, N. 1972b. Présence de Diplopora dans le Carbonifère (description d'une nouvelle espèce du Viséen du Maroc). Türkiye Jeololoji Kurumu Bülteni 15, 14-20.

Chuvashov, B.I. 1965. Foraminifers and algae of the Upper Devonian deposits from the western slope of the central and southern Urals. Devonian and Permian Foraminifera of the Urals. Sbornik po stratigrafii 8(74), 3-154. Institute of Geology, Ural Branch of the USSR, Sverdlovsk. [in Russian]

Chuvashov, B.I. 1974. Permian calcareous algae from the Urals, 1-76. In Papulov, G.N. \& Chuvashov, B.I. (eds) Algae, brachiopods and miospores from the Permian deposits of western Urals. Akademiya nauk SSSR, Uralskii nauchnyi tsentr, Trudy Instituta geologii i geokhimii 109. [in Russian]

Chuvashov, B.I. \& Anfimov, A.L. 1988. New calcareous algae from Middle Carboniferous to Early Permian of the Urals and Preural, 54-70. In Zhuravleva, I.T. \& Puchrov, V.M. Calcareous algae and stromatolites. Izdatelstvo Nauka, Moscow. [in Russian]

Chuvashov, B.I., Luchinina, V.A., Shuysky, V.P., Shaikin, I.M., Berchenko, O.I., Ishchenko, A.A., Saltovskaya, V.D. \& SHIRSHOVA, D.I. 1987. Fossil calcareous algae, morphology, systematics, methods of study. Akademiya nauk SSSR, Sibirskoe otdelenie, Trudy Instituta geologii i geofiziki 674, 5-224. [in Russian]

Conil, R., Longerstaey, P.J. \& Ramsbottom, W.H.C. 1980. Matériaux pour l'étude micropaléontologique du Dinantien de Grande-Bretagne. Mémoires de l'Institut géologique de l'Université de Louvain 30(1979), 1-115.

CózAr, P. 2004. Foraminiferal and algal evidence for the recognition of the Asbian/Brigantian boundary in the Guadiato Area (Mississippian, Southwestern Spain). Revista Española de Micropaleontología 36, 367-388.

CózAR, P. 2005. Early Serpukhovian (late Mississippian) microflora from the Guadiato Area (southwestern Spain). Geological Journal 40, 405-424. DOI 10.1002/gj.1014

Cózar, P. \& Rodríguez, S. 1999a. Descripción e interpretación de los afloramientos del Carbonífero inferior en la proximidades de Peñarroya-Pueblonuevo (Córdoba, España). Coloquios de Paleontología 50, 161-200.

Cózar, P. \& Rodríguez, S. 1999b. Sedimentología y bioestratigrafía del Viseense y Serpujoviense del área de Sierra Palacios, Valle del Guadiato (Córdoba, España). Boletín de la Real Sociedad Española de Historia Natural (Sección Geológica) 95, 47-65.

Cózar, P., Said, I., Somerville, I.D., Vachard, D., Medina-Varea, P., Rodríguez, S. \& Berkhli, M. 2011. Potential foraminiferal markers for the Visean-Serpukhovian and Serpukhovian-Bashkirian boundaries - A case-study from central Morocco. Journal of Paleontology 85(6), 1105-1127. DOI 10.1666/10-158.1

Cózar, P. \& Somerville, I.D. 2004. New algal and foraminiferal assemblages and evidence for recognition of the Asbian/Brigantian boundary in northern England. Proceedings of the Yorkshire Geological Society 55, 43-65. DOI 10.1144/pygs.55.1.43

Cózar, P. \& Somerville, I.D. 2005a. Stratigraphy of upper Visean carbonate platform rocks in the Carlow area, southeast Ireland. Geological Journal 40(1), 35-64.

DOI 10.1144/pygs.55.1.43

CózAr, P. \& SomervilLe, I.D. 2005b. Significance of calcareous algae for the recognition of the Asbian and Brigantian stages (Mississippian) in Ireland and Great Britain. Revista Española de Micropaleontología 37(1), 71-94.

Cózar, P. \& Somerville, I.D. 2005c. Late Visean calcareous algal assemblages in south-eastern Ireland. Neues Jahrbuch für Geologie und Paläontologie, Monatshefte 2005(2), 95-117.

Cózar, P. \& Somerville, I.D. 2014. Foraminiferal early Namurian/Serpukhovian (Carboniferous) correlations: implications for biostratigraphic and glacioeustatic correlations. Newsletters on Stratigraphy 47, 355-367.

DOI 10.1127/nos/2014/0052 
Cózar, P. \& Somerville, I.D. 2015. Problems correlating the late Brigantian-Arnsbergian Western European substages within northern England. Geological Journal. DOI 10.1002/gj.2700

Cózar, P., Somerville, I.D., Rodríguez, S. \& Medina-Varea, P. 2007. New genera of late Visean metaspondil dasycladales from the Fuenteobejuna section (Mississippian of the Guadiato Valley, southwestern Spain). Neues Jahrbuch für Geologie und Paläontologie, Abhandlungen 246(1), 97-109. DOI 10.1127/0077-7749/2007/0246-0097

CÓZAR, P. \& VACHARD, D. 2003. Neoprincipia nov. gen., a new Mississippian red alga, and remarks on the Archaeolithophyllaceae (Rhodophyta). Geobios 36, 505-517. DOI 10.1016/S0016-6995(03)00060-3

Cózar, P. \& Vachard, D. 2004. A new Mississippian dasyclad alga (Chlorophyta) from SW Spain; implications for the reproductive evolution of the dasyclads during the Late Paleozoic. Eclogae geologicae Helvetiae 97, 175-181. DOI 10.1007/s00015-004-1127-4

Cózar, P. \& VAChard, D. 2005. Comparaison d'Hortonella (algue rouge du Carbonifère) avec une structure algaire problématique (racine?): Lysvaella. Revue de Paléobiologie 24(1), 243-249.

Cózar, P. \& Vachard, D. 2006. A new Mississippian red alga from south-western Spain. Geobios 39, 791-803. DOI 10.1016/j.geobios.2005.09.002

Cózar, P., Vachard, D., Medina-Varea, P., Said, I., SomerVILLE, I.D., Rodríguez, S. \& Berkhli, M. 2008. Late Viseanearly Serpukhovian foraminiferans and calcareous algae from the Adarouch region (central Morocco). Geological Journal 43, 463-485. DOI 10.1002/gj.1119

Cózar, P., Vachard, D., Somerville, I.D., Medina-Varea, P., Rodríguez, S. \& SAID, I. 2014. The Tindouf Basin, a marine refuge during the Serpukhovian (Carboniferous) mass extinction in the northwestern Gondwana platform. Palaeogeography, Palaeoclimatology, Palaeoecology 394, 12-28. DOI 10.1016/j.palaeo.2013.11.023

Cózar, P., Vachard, D., Somerville, I.D., Pille, L. \& MeDinA-VAREA, P. 2009. Revision and new species of the Late Palaeozoic dasyclad algae Windsoporella and Eovelebitella. Palaeontographica, Abteilung B 282, 39-67.

Cummings, R.H. 1955a. New genera of foraminifera from the British Lower Carboniferous. Journal of the Washington Academy of Sciences 45(1), 1-8.

Cummings, R.H. 1955b. Stacheoides, a new foraminiferal genus from the British Upper Paleozoic. Journal of the Washington Academy of Sciences 45(11), 342-346.

Deloffre, R. 1987. Nouvelle classification des algues Dasycladales fossiles. Comptes Rendus de l'Académie des Sciences 305, série II, 1017-1020.

Deloffre, R. 1988. Nouvelle taxonomie des algues dasycladales. Bulletin des Centres Recherche Exploration-Production Elf-Aquitaine 12(1), 165-217.

Delvolvé, J.J., HansotTe, M. \& Vachard, D. 1994. Biostratigraphy by foraminifera and algae of the Carboniferous deposits (uppermost Viséan-Serpukhovian) of the Arize Massif (Ariège, France). Neues Jahrbuch für Geologie und Paläontologie, Abhandlungen 192(2), 183-201.

Delvolvé, J.J., Vachard, D. \& Souquet, P. 1998. Stratigraphic record of thrust progradation, Carboniferous foreland basin, Pyrenees, with emphasis on Pays-de-Sault (France/Spain).
Geologische Rundschau 87, 363-372.

DOI $10.1007 / \mathrm{s} 005310050215$

Deninger, K. 1906. Einige neue Tabulaten und Hydrozoen aus den mesozoischen Ablagerungen. Neues Jahrbuch für Mineralogie, Geologie und Paläontologie 1, 61-70.

Devuyst, F.X. 2006. The Tournaisian-Visean boundary in Eurasia. Definition, biostratigraphy, sedimentology and early evolution of the genus Eoparastaffella (foraminifer). Thèse de l'Université Catholique de Louvain, Louvain-la-Neuve.

DyвоwsкI, W. 1878. Die Chaetetiden der ostbaltischen Silur-Formation. Russisch-Kaiserlische Mineralogische Gesellschaft zu St. Petersburg Verhandlungen 2(14), 1-134.

Ehrenberg, C.G. 1854. Zur Mikrogeologie. 374 pp. Verlag von Leopold Voss, Leipzig.

ElliotT, G.F. 1968a. Permian to Palaeocene calcareous algae (Dasycladaceae) of the Middle East. Bulletin of the British Museum (Natural History), Geology, supplement 4, 1-111.

ElliotT, G.F. 1968b. Three new Tethyan Dasycladaceae (calcareous algae). Palaeontology 11, 491-497.

Elliott, G.F. 1970. Calcareous algae new to the British Carboniferous. Palaeontology 13(3), 443-450.

Elliott, G.F. 1971. The nature of Aciculella Pia (calcareous algae). Palaeontology 14(14), 629-636.

Emberger, J. 1976. Les algues (Chlorophyceae, Prasinophyceae, Rhodophyceae) du Carbonifère et du Permien. Essai d'un inventaire bibliographique, géographique, stratigraphique. Bulletin de l'Institut de Géologie du Bassin d'Aquitaine, numéro special, 1-168.

ENDO, R. 1951. Stratigraphical and paleontological studies of the Later Paleozoic calcareous algae in Japan I. Transactions and Proceedings of the Paleontological Society of Japan, new series $5,121-129$.

ENDO, R. 1957. Stratigraphical and paleontological studies of the Later Paleozoic calcareous algae in Japan XI. Fossil algae from the Taishaku district, Horishima-ken, and Kitamino-kuni, Hokkaido. Science Reports Saitama University, series $B$ 2, 279-305.

ENDO, R. 1961a. Phylogenetic relationships among the calcareous algae. The Science Reports of the Saitama University, series B, Commemorative Volume R. Endo, 1-52.

Endo, R. 1961b. Stratigraphical and paleontological studies of the Later Paleozoic calcareous algae in Japan XVII. Fossil algae from the Akiyoshi Limestone Group. The Science Reports of the Saitama University, series B, Commemorative Volume R. Endo, 119-142.

ENDO, R. \& Kanuma, M. 1954. Stratigraphical and paleontological studies of the later Paleozoic calcareous algae in Japan VII. Geology of the Mino mountainland and southern part of Hida plateau with description of the algal remains found in those districts. The Science Reports of the Saitama University, series B 1, 177-205.

Engel, W., Feist, R. \& Franke, W. 1982. Le Carbonifère anté-stéphanien de la Montagne Noire: rapports entre mise en place des nappes et sédimentation. Bulletin du Bureau de Recherches Géologiques et Minières (B.R.G.M.) (deuxième série) section 14 (1980-1981), 341-389.

Falahatgar, M., Vachard, D. \& Ahmadi Sakha, L. 2015. The Tournaisian (Early Carboniferous) of the Kahanag section (central Alborz; northern Iran); biostratigraphy with calcare- 
ous algae and foraminifers; palaeobiogeographic implications. Revue de Micropaléontologie 58, 217-237.

DOI 10.1016/j.revmic.2015.07.002

Feist, F. \& Gaultier, J. 1985. Découverte de flores d'âge namurien probable dans le flysch à olistolites de Cabrières (Hérault). Implication sur la durée de la sedimentation synorogénetique dans la Montange Noire (France méridionale). Comptes Rendus de l'Académie des Sciences Paris, Série II 300, 207-212.

Feldman, J. 1946. Sur l'hétéroplastie de certaines Siphonales et leur classification. Comptes Rendus de l'Académie des Sciences 13(222), 752-753.

Flügel, E. 1966. Algen aus dem Perm der Karnischen Alpen. Carinthia II 25, 3-76.

FlÜGEL, E. \& FlÜGEL-KAHLER, E. 1980. Algen aus den Kalken der Trogkofel-Schichten der Karnischen Alpen. Carinthia II Sonderheft 36, 113-182.

Gaillot, J. \& Vachard, D. 2007. The Khuff Formation (Middle East) and time-equivalents in Turkey and South China: biostratigraphy from Capitanian to Changhsingian times (Permian), new foraminiferal taxa, and palaeogeographical implications. Coloquios de Paleontología 57, 37-223.

GARWOOD, E.J. 1914. Some new rock-building organisms from the Lower Carboniferous beds of Westmorland. Geological Magazine 51, 265-271. DOI 10.1017/S0016756800196955

GĖzE, B. 1949. Etude géologique de la Montagne Noire et des Cévennes méridionales. Mémoires de la Société géologique de France, nouvelle série 29(62), 1-215.

GIRTY, G.H. 1908. On some new and old species of Carboniferous fossils. Proceedings of the United States National Museum 34, 181-303. DOI 10.5479/si.00963801.34-1614.281

GolubTsov, V.K. 1961. Kulikia, new genus of calcareous algae in the Visean stage, 348-353. In Fursenko, A.V. (ed.) Palaeontology and stratigraphy BSSR. Izdatelstvo Akademii nauk Beloruss SSR, Minsk. [in Russian]

Granier, B. 2015. Algas calcárias marinhas bentônicas no Cretáceo do Brasil, 518-567. In Dias-Brito, D. \& Tibana, P. (eds) Atlas dos Calcários do Cretáceo do Brasil: um Atlas. IGCE/UNESP/Rio Claro, UNESPetro, Obra 1, Rio de Janeiro.

Granier, B., Berthou, P.-Y. \& Poignant, A.-F. 1991. Constructions bio-sédimentaires laminées, Lithothamnium et Parachaetetes de la Formation Riachuelo (Albien) du bassin de Sergipe (Nord-Est du Brésil). Geociências, Sao Paolo 10, 169-181.

Granier, B. \& Deloffre, R. 1995. Inventaire critique des algues dasycladales fossiles, III $^{\mathrm{e}}$ partie: les algues dasycladales du Permien et du Trias. Revue de Paléobiologie 14, 49-84.

Granier, B. \& Dias-Brito, D. 2016. On the fossil alga Elianella elegans Pfender \& Basse, , and its so-called lookalikes, with description of Elianella brasiliana n. sp. Revision of the Juliette Pfender Collection. Part 1. Carnets de Géologie 16(6), 213-229. DOI $10.4267 / 2042 / 59920$

GraniER, B.R.C. \& GRgasovic, T. 2000. Les algues dasycladales $\mathrm{du}$ Permien et $\mathrm{du}$ Trias. Nouvelle tentative d'inventaire bibliographique, géographique et stratigraphique. Geologia Croatica 53, 1-197.

Granier, B. \& Hofmann, T. 2002. Un guide pour la collection de Julius Pia $2^{\text {ème }}$ partie. A guide to the collection of Julius Pia. $2^{\text {nd }}$ Part, 135-144. In Bucur, I.I. \& Filipescu, S. (eds) Research advances in calcareous algae and microbial carbonates. Cluj University Press, Cluj.
Groves, J.R. 1983. Calcareous foraminifers and algae from the type Morrowan (Lower Pennsylvanian) region of northeastern Oklahoma and northwestern Arkansas. Oklahoma Geological Survey Bulletin 133, 1-39.

Groves, J.R., Wang Yue, Qi Yuping, Richards, B.C., Ueno, K. \& WANG XiAngdong 2012. Foraminiferal biostratigraphy of the Visean-Serpukhovian (Mississippian) boundary interval at slope and platform sections in Southern Guizhou (South China). Journal of Paleontology 86(5), 753-774.

Güvenç, T. 1966. Description de quelques espèces d'algues calcaires (Gymnocodiacées et Dasycladacées) du Carbonifère et du Permien des Taurus Occidentaux. Revue de Micropaléontologie 9, 94-103.

Güvenç, T. 1972. Un nouveau genre d'algue calcaire du Permien Embergerella sp. Türkiye Jeoloji Kurumu Bülteni 15, 21-25.

Güvenç, T. 1979. Daycladacées métaspondyles du Paléozoique supérieur et du Trias. Bulletin des Centres Recherche Exploration-Production Elf-Aquitaine 3(3), 625-637.

HALLETT, D. 1970. Foraminifera and algae from the Yoredale "series" (Visean-Namurian) of Northern England. Comptes Rendus du $\sigma^{e}$ Congrès International de Stratigraphie et de Géologie du Carbonifère (Sheffield, 1967) 3, 873-895.

Harris, A.G., Brenckle, P.L., Baesemann, J.F., Krumhardt, A.P. \& Gruzlovic, P.D. 1997. Comparison of Conodont and Calcareous Microfossil Biostratigraphy and Lithostratigraphy of the Lisburne Group (Carboniferous), Sadlerochit Mountains, Northeast Brooks Range, Alaska, 195-219. In Dumoulin, J.A. \& Gray, J.E. (eds) Geologic studies in Alaska by the U.S. Geological Survey, 1995. U.S. Geological Survey Professional Paper 1574.

Haug, E. 1883. Über sogenannte Chaetetes aus mesozoischen Ablagerungen. Neues Jahrbuch für Mineralogie 1, 171-179.

Herbig, H.G. \& Mamet, B. 1985. Stratigraphy of the limestone boulders, Marbella Formation (Betic Cordillera, Southern Spain). Comptes Rendus du $10^{e}$ Congrès International de Stratigraphie et Géologie du Carbonifère, Madrid 1983 1, 199-212.

Herbig, H.G. \& MAMET, B. 1994. Hydraulic sorting of microbiota in calciturbidites. A Dinantian case study from the Rheinische Schiefergebirge, Germany. Facies 31, 93-104. DOI 10.1007/BF02536935

HøEG, O.A. 1932. Ordovician algae from the Trondheim area. Norske Videnskap Akademie Oslo 1, 63-96.

HomanN, W. 1972. Unter- und tief-mittelpermische Kalkalgen aus dem Rattendorfer Schichten, dem Trogkofel Kalk und dem Tressdorfer Kalk der Karnischen Alpen (Österreich). Senckenbergiana lethaea 53(3/4), 135-313.

IvANOVA, R.M. 1973. On the stratigraphy from the middle and late Visean of the southern slope of the southern Urals, 18-86. In Malakhova, N.P. \& Chuvashov, B.I. (eds) Early Carboniferous from the eastern slope of the southern Urals. Akademiya nauk SSSR, Ural Nauchnyi tsentr, Trudy Instituta geologii i geokhimii 82. [in Russian]

Ivanova, R.M. 1988. Calcareous algae of the Visean stage in the Urals, 4-19. In Chuvashov, B.I. \& Puchkov, B.N. (eds) Upper Palaeozoic biostratigraphy and lithology of the Urals. Akademiya nauk SSSR, Uralskoe otdelenye, Sbornik nauchnykh trudov. [in Russian]

Ivanova, R.M. \& Bogush, O.I. 1992. Algae as indicators of a biogeographical zonation in the Early Carboniferous of the 
Urals, Siberia and Northeast Russia. Facies 27, 235-244. DOI 10.1007/BF02536815

Johnson, J.H. 1946. Lime-secreting algae from the Pennsylvanian and Permian of Kansas. Geological Society of America Bulletin 57, 1080-1120.

Johnson, J.H. 1956. Archaeolithophyllum, a new genus of Paleozoic coralline algae. Journal of Paleontology 30(1), 53-55.

Johnson, J.H. \& HøEG, O.V. 1961. Studies of Ordovician algae. Quarterly of the Colorado School of Mines 56(2), 1-101.

Johnson, J.H. 1964. Lower Devonian Algae and encrusting foraminifera from New South Wales. Journal of Paleontology 38(1), 98-108

Johnson, J.H. \& Konishi, K. 1956. Mississippian algae from the Western Canada Basin and Montana, 85-107. In JoHnson, J.H. \& Konishi, K. Studies of Mississippian algae. Quarterly of the Colorado School of Mines 51(4).

Karim, A., Berkhli, M., Vachard, D., Tribovillard, N. \& Orberger, B. 2005. Le Viséen supérieur d'Azarhare (Maroc central): environnements de dépôt, datation et évolution diagénétique. Comptes Rendus Geoscience 337, 525-532. DOI 10.1016/j.crte.2004.11.003

Kochansky-DevidÉ, V. 1964. Velebitella, eine neue jungpaläzoische Diploporeengattung und ihre phylogenetischen Verhältnisse. Geološki Vjesnik 17, 135-142.

Kochansky-Devidé, V. \& Gusic, M. 1971. Evolutions-Tendenzen der Dasycladaceen mit besonderer Berücksichtigung neuer Funde in Jugoslawien. Paläontologische Zeitschrift 45(1/2), 82-91. DOI 10.1007/BF02989679

Kochansky-Devidé, V. \& HeraK, M. 1960. On the Carboniferous and Permian Dasycladaceae of Yugoslavia. Geološki Vjesnik 13, 65-94.

KonISHI, K. 1956. Anatolipora, a new Dasycladacean genus, and its algal associates from the Lower Carboniferous of Japan, 109-127. In Johnson, J.H. \& Konishi, K. Studies of Mississippian algae. Quarterly of the Colorado School of Mines 51(4).

KoRDÉ, K.B. 1950. Algal remains from the Cambrian of Kazakhstan. Doklady Akademii nauk SSSR, n. s. 73(4), 809-812. [in Russian]

Kordé, K.B. 1973. Cambrian algae. Akademiya nauk SSSR, Trudy Paleontologicheskogo instituta 139, 1-34. [in Russian]

Korn, D. \& FEIST, R. 2007. Early Carboniferous ammonoid faunas and stratigraphy of the Montagne Noire (France). Fossil Record 10(2), 99-124. DOI 10.1002/mmng.200700002

Kozlowski, R. \& KazmierczaK, J. 1968. On two Ordovician calcareous algae. Acta Paleontologica Polonica 13(3), 325-346.

KRAINER, K. \& VACHARD, D. 2002. Late Serpukhovian (Namurian A) microfacies and carbonate microfossils from the Carboniferous of Nötsch (Austria). Facies 46, 1-26. DOI 10.1007/BF02668070

Krings, S., Bless, M.J.M., Conil, R., Felder, P.J. \& Meesen, J.P.M.T. 1987. Stratigraphic interpretation of the Thermae boreholes (Valkenburg a/d Geul, The Netherlands). Annales de la Société Géologique de Belgique 110, 9-38.

KuliK, E.L. 1973. Cyanophyta, 39-48. In Einor, O.L. (ed.) Carboniferous stratigraphy and fauna of Shartym river (southern Urals). Uralskoe geologicheskoe upravlenie, Kievskii ordena Lenina Gosudarstvennyi universitet, Izdatelskoe obedisenie "Vishcha shkola", Lvov. [in Russian]
KütZing, F.T. 1843. Phycologia Generalis oder Anatomie, Physiologie und Systemkunde der Tange. 458 pp. F.A. Brockhaus Verlag, Leipzig.

LeE, G.W. 1912. The British Carboniferous Trepostomata. Memoirs Geological Survey Great Britain, Palaeontology 1(3), 135-195.

Lemosquet, Y. \& Poncet, J. 1977. Etude de quelques Algues calcaires et de quelques microfaciès du Carbonifère du bassin de Béchar (Sahara Sud-Oranais, Algérie). Bulletin de la Société géologique de France, 7 e série 19, 335-339.

Ma Lu, Wang Jianpo, Zhang Yuanyuan, Wang Guan \& Li Yue 2014. Boundstones from the Upper Ordovician Lianglitag Formation in the central Tarim, Xinjiang, NW China. Acta Micropaleontologica Sinica 31(2), 154-163.

Madi, A., Bourque, P.A. \& Mamet, B. 1996. Depth-related ecological zonation of a Carboniferous carbonate ramp: Upper Visean of Béchar Basin, western Algeria. Facies 35, 59-80. DOI 10.1007/BF02536957

Mamet, B. 1968. Sur les microfaciès calcaires du Viséen de la Montagne Noire (France). Revue de Micropaléontologie 11(3), 121-136.

Mamet, B.L. 1974. Sur deux dasycladacées carbonifères des Cordillères nord-américaines. Revue de Micropaléontologie 17(1), 38-44.

Mamet, B. 1976. An atlas of microfacies in Carboniferous carbonates of the Canadian Cordillera. Geological Survey Canada 255, 1-131.

MAMET, B.L. 1991. Carboniferous calcareous algae, 370-451. In RIDING, R. (ed.) Calcareous algae and stromatolites. Springer-Verlag, Berlin \& Heidelberg.

MAMET, B. 1995. Hortonella uttingii, gen. nov., sp. nov., Udotéacées? (Algues vertes?) du Carbonifère inférieur. Canadian Journal of Earth Sciences 32(8), 1267-1272. DOI 10.1139/e95-103

Mamet, B. 1997. Pseudokulikia, a new Viséan green alga from Morocco. Revue de Micropaléontologie 40(4), 331-338. DOI 10.1016/S0035-1598(97)90674-7

MAмEт, B. 1998. A Late Devonian microfossil with dasyclad algae affinities from northwestern Australia. Alcheringa 22, 21-28. DOI 10.1080/03115519808619237

MAMET, B.L. 2002. Carboniferous marine algae, lower part of Akiyoshi Limestone Group, Japan, 492-528. In Hills, L.V., Henderson, C.M. \& Bamber, E.W. (eds) Carboniferous and Permian of the World. Memoir of Canadian Society of Petroleum Geologists, Calgary 19.

Mamet, B. 2006. Taxonomy of Viséan marine calcareous algae, Fernie, British Columbia (Canada). Rivista Italiana de Stratigrafia e Paleontologia 112(3), 323-357.

Mamet, B. \& Boulvain, F. 1992. Microflore des monticules micritiques frasniens "F2j" de Belgique (Frasnian mudmound microflora, "F2j", Belgium). Revue de Micropaléontologie 35(4), 283-302.

Mamet, B., Dejonghe, L. \& Roux, A. 1980. Sur la présence de Kulikia (Dasycladacée) dans le Viséen des Grands Malades (Jambes). Bulletin de la Société belge de géologie 89(4), 291-295.

Mamet, B. \& Martínez, C. 1981. Late Viséan microfossils of the Las Caleras Bajas Limestone (Córdoba, Spain). Revista Española de Micropaleontología 13(1), 105-118.

MAмет, В. \& Miší, M. 2003. Marine Carboniferous algae from 
metacarbonates of the Ochtiná Formation (Gemeric Unit, western Carpathians). Geologica Carpathica 54(1), 3-8.

Mamet, B., Mortelmans, G. \& Roux, A. 1978. Algues viséennes du sondage de Turnhout (Campine, Belgique). Annales de la Société géologique de Belgique 101, 351-383.

Mamet, B. \& PrÉAt, A. 2010. Un atlas d'algues calcaires; Carbonifère, Alaska arctique. Carnets de Géologie (2010: Livre 1-Book 1).

Mamet, B. \& PrÉat, A. 2013. Esssai de description d'algues nouvelles paléozoïques. Geologica Belgica 16(1/2), 35-48.

Mamet, B. \& Roux, A. 1974. Sur quelques algues tubulaires scalariformes de la Téthys paléozoïque. Revue de Micropaléontologie 17(3), 134-156.

Mamet, B. \& Roux, A. 1975a. Dasycladales dévoniennes et carbonifères de la Téthys occidentale. Revista Española de Micropaleontología 7(2), 245-295.

Mamet, B. \& Roux, A. 1975b. Algues dévoniennes et carbonifères de la Téthys occidentale, Troisième partie. Revue de Micropaléontologie 18(3), 134-187.

Mamet, B. \& Roux, A. 1977. Algues rouges dévoniennes et carbonifères de la Téthys occidentale, 4e partie. Revue de Micropaléontologie 19(4), 215-266.

Mamet, B. \& Roux, A. 1978. Algues viséennes et namuriennes $\mathrm{du}$ Tennessee (Etats-Unis). Revue de Micropaléontologie 21(2), 68-97.

Mamet, B. \& Roux, A. 1981. Note sur les Albertaporellinae (Dasycladaceae). Revue de Micropaléontologie 23(3/4), 159-168.

Mamet, B. \& Roux, A. 1983. Algues dévono-carbonifères de l'Australie. Revue de Micropaléontologie 26(2), 63-131.

Mamet, B.L., Roux, A. \& Nassichuk, W.W. 1987. Algues carbonifères et permiennes de l'Arctique canadien. Geological Survey of Canada, Bulletin 342, 1-143. DOI $10.4095 / 122452$

Mamet, B. \& Rudloff, B. 1972. Algues carbonifères de la partie septentrionale de l'Amérique du Nord. Revue de Micropaléontologie 15(2), 75-114.

Mamet, B. \& Villa, E. 2004. Calcareous marine algae from the Carboniferous (Moscovian-Gzhelian) of the Cantabrian zone (NW Spain). Revista Española de Paleontología 19, 151-190.

Maslakova, N. I., 1990. Criteria of establishing of higher taxa in Foraminifera, 22-27. In MenNeR, V.V. Systematics and phylogeny of Invertebrata: the criteria for establishing higher taxa. Izdatelstvo Nauka, Moscow. [in Russian]

Maslov, V. 1929. Microscopic algae from the Carboniferous limestones of the Donets Basin. Izvestii Geologicheskogo Komiteta 48(10), 115-138. [in Russian]

MasLov, V.P. 1950. Importance of red algae for the stratigraphy of USSR. Doklady Akademii nauk SSSR 70(1), 75-78. [in Russian]

MasLov, V.P. 1956. Fossil calcareous algae from USSR. Trudy Instituta geologichesnikh nauk, Akademiya nauk SSSR 160, 1-301. [in Russian; French translation BRGM No. 3517]

MAsLov, V.P. 1973. Atlas of rock-building organisms (calcareous and siliceous organisms). Izdatelstvo Nauka, Moscow. [in Russian]

MAY, A. 1992. Die Kalkalgen-Flora des Ober-Eifeliums und Unter-Givetiums (Devon) des nordwestlichen Sauerlandes (Rheinisches Schiefergebirge). Palaeontographica, Abteilung B 228, 1-28.
McCoy, F. 1849. On some new genera and species of Palaeozoic corals and foraminifera. The Annals and Magazine of Natural History, series $23,119-136$.

DOI 10.1080/03745485909494579

MöLlER, V. von 1879. Die Foraminiferen des russischen Kohlenkalks. Mémoires de l'Académie Impériale des Sciences de St. Pétersbourg, $7^{\text {th }}$ series 27(5), 1-131.

NGuyen Duc Tien 1989. Middle Permian Foraminifera, 113-166. In Fontaine, H. \& Gafoer, S. (eds) The Pre-Tertiary fossils of Sumatra and their environments. CCOP Technical Publication 19, Bangkok.

Nicholson, H.A. \& Etheridge, R. 1878. A Monograph of the Silurian Fossils of the Girvan District of Ayrshire with Special Reference to Those Contained in the "Gray Collection". Scotland Geological Survey Memoirs 1(1), 1-135.

OKuYucu, C., VAChaRd, D. \& GöNCÜOĞLU, M.C. 2013. Refinements in biostratigraphy of the foraminiferal zone MFZ11 (middle Visean, Mississippian) in the Cebeciköy Limestone (Istanbul Terrane, NW Turkey), palaeogeographic implications. Bulletin of Geosciences 88, 621-645.

DOI 10.3140/bull.geosci.1387

Ouarache, D., Baudelot, S., Charrière, A., Perret, M.F. \& VACHARD, D. 1991. Nouvelles datations micropaléontologiques et palynologiques dans le Viséen de la bordure nord-occidentale du Causse Moyen-atlasique (Maroc). Géologie Méditerranéenne 18(1-2), 43-59.

PANTIC, S. 1971. Baccanella floriformis n. gen. n. sp. from the Middle Triassic of the Dinarides. Annales Géologiques de la Péninsule Balkanique 36, 105-111.

PAPENFUSS, G.F. 1946. Classification of the algae, 115-224. In KeSSEL, E.L. (ed.) A century of progress in the natural sciences 1853-1953. California Academy of Science, San Francisco.

PAscher, A. 1931. Systematische Übersicht über die mit Flagellaten in Zusammenhang stehenden Algenreihen und Versuch einer Einreihung dieser Algenstämme in die Stämme des Pflanzenreiches. Beihefte zum Botanischen Zentralblatt 48, 317-332.

Perret, M.F. \& VAChard, D. 1977. Algues et pseudo-algues des calcaires serpoukhoviens d'Ardengost (Hautes-Pyrénées). Annales de Paléontologie (Invertébrés) 63(2), 85-156.

Peterhans, E. 1929. Algues de la famille des Solénoporacées dans le Malm du Jura bâlois et soleurois. Mémoires de la Société Paléontologique Suisse 40, 1-15.

Petryk, A.A. \& Mamet, B.L. 1972. Lower Carboniferous algal microflora, southwestern Alberta. Canadian Journal of Earth Sciences 9(7), 767-802. DOI 10.1139/e72-064

Pfender, J. 1939. Sur un calcaire phytogène du Lias inférieur d'Espagne et l'extension de ce faciès en quelques autres régions. Bulletin de la Société Vaudoises des Sciences Naturelles 60(248), 213-228.

PIA, J. von 1912. Neue Studien über die triadischen Siphoneae verticillatae. Beiträge zur Paläontologie und Geologie Österreich-Ungarns und des Orients 25, 25-81.

PIA, J. von 1920. Die Siphoneae verticillatae vom Karbon bis zur Kreide. Abhandlungen der zoologisch-botanischen Gesellschaft in Wien 11(2), 1-263 (French translation: Editions Technip, Paris).

PIA, J. vON 1922. Einige Ergebnisse neuerer Untersuchungen über die Geschichte der Siphoneae verticillatae. Zeitschrift für induktive Abstammungs- und Vererbungslehre 30, 63-98. 
PIA, J. von 1927. Thallophyta, 31-136. In HiRMer, M. (ed.) Handbuch der Paläobotanik. Band: Thallophyta, Bryophyta, Pteridophyta. Verlag R. Oldenburg, München \& Berlin.

PIA, J. vON 1930. Upper Triassic fossils from the Burmo-Siamese frontier - A new Dasycladacea, Holosporella siamensis nov. gen., nov. sp. with a description of the allied genus Aciculella Pia. Records of the Geological Survey of India 53(4), 177-181.

PIA, J. vON 1937. Die wichtigsten Kalkalgen des Jungpaläozoikums und ihre geologische Bedeutung. Compte Rendu du 2e Congrès Avancement Etudes de Stratigraphie du Carbonifère, Heerlen 1935(2), 765-856.

Pille, L. 2008. Foraminifères et algues calcaires du Mississippien supérieur (Viséen supérieur-Serpukhovien): rôles biostratigraphique, paléoécologique et paléogéographique aux échelles locale, régionale et mondiale. $\mathrm{PhD}$ thesis, Université de Lille.

Pille, L. \& Vachard, D. 2011. Diploporaceae (calcareous green algae dasycladales) from the late Visean (Mississippian) of Montagne Noire (southern France). Revue de Micropaléontologie 54, 1-30. DOI 10.1016/j.revmic.2009.02.001

Poignant, A.F. 1991. The Solenoporaceae: A general point of view, 88-97. In Riding, R. (ed.) Calcareous algae and stromatolites. Springer Verlag, Berlin, Heidelberg, New York, London, Paris, Tokyo, Hong Kong, Barcelona.

PokoRnÝ, V. 1951. The Middle Devonian foraminifera of Celechovice, Czechoslovakia. Věstník Královské České společnosti nauk, Tř́da matematicko-přirodovědecká 9, 1-29.

Poncet, J. 1965. Sur une Dasycladacée nouvelle du Dévonien inférieur: Diplopora constantini nov. sp. Bulletin de la Société géologique de France, 7 e série 7, 879-880.

Poncet, J. 1986. Les algues calcaires du Carbonifère moyen du bassin de Béchar (Sahara algérien). Revue de Micropaléontologie 29, 187-197.

Poty, E., Aretz, M. \& Barchy, L. 2002. Stratigraphie et sédimentologie des "Calcaires à Productus" du Carbonifère inférieur de la Montagne Noire (Massif Central, France). Comptes Rendus Geoscience 334(11), 843-848. DOI 10.1016/S1631-0713(02)01818-7

Praturlon, A. 1963. Dasycladaceae from the Upper Permian of the Dolomites (Italy). Geologica Romana 2, 119-150.

RÁCZ, L.G. 1964. Carboniferous calcareous algae and their associations in the San Emiliano and Lois-Ciguera formations (Province of León, NW Spain). Leidse geologische Mededelingen 31, 1-112.

RÁcz, L. 1966. Late Palaeozoic calcareous algae in the Pisuerga Basin (N.-Palencia, Spain). Leidse geologische Mededelingen 31, 241-260.

RAdOICIC, R. 1959. Some problematic microfossils from the Dinarian Cretaceous. Bulletin Service Géologie Géophysique Serbie 17, 87-92.

REITLINGER, E.A. 1954. Devonian foraminifers from the eastern part of the Russian Platform. Paleontologicheskii sbornik VNIGRI 1, 41-51. [in Russian]

Rich, M. 1974. Upper Mississippian (Carboniferous) calcareous algae from Northeastern Alabama, South-Central Tennessee and Northwestern Georgia. Journal of Paleontology 48(2), 360-374.

RIDING, R. 1975. Girvanella and other algae as depth indicators. Lethaia 8, 173-179. DOI 10.1111/j.1502-3931.1975.tb01310.x
Riding, R. 1991. Chapter 3, Calcified cyanobacteria, 55-87. In RIDING, R. (ed.) Calcareous algae and stromatolites. Springer Verlag, Berlin, Heidelberg, New York, London, Paris, Tokyo, Hong Kong, Barcelona.

Riding, R. 2004. Solenopora is a chaetetid sponge, not an alga. Palaeontology 47(1), 117-122. DOI 10.1111/j.0031-0239.2004.00351.x

RothplETZ, A. 1908. Über Algen und Hydrozoen im Silur von Gotland und Oesel. Kungliga Svenska Vetenskaps Akademiens Handlingar 43(5), 1-23. DOI 10.1007/bf01990621

RothPletZ, A. 1913. Über die Kalkalgen, Spongiostromen und einige andere Fossilien aus dem Obersilur Gotlands. Sveriges Geologiska Undersökning C 10, 1-57.

Roux, A. 1979. Révision du genre Epimastopora "Pia, 1922" (Dasycladaceae). Bulletin des Centres Recherche Exploration-Production Elf-Aquitaine 3(2), 803-810.

Roux, A. 1985. Introduction à l'étude des algues fossiles paléozoïques (de la bactérie à la tectonique des plaques). Bulletin des Centres de Recherches Exploration-Production Elf-Aquitaine 9(2), 465-699.

Saltovskaya, V.D. 1974. Stratigraphy of the Carboniferous deposits of the mountainous area Zeravhan-Gissar. 144 pp. Izdatelstvo Donish, Dushanbe. [in Russian]

Saltovskaya, V.D. 1984. Some calcareous algae from the Palaeozoic of Tadzhikistan, 141-160. In Dzhalilov, M.R. (ed.) New species of fossil fauna and flora of Tadzhikistan. Izdatelstvo Donish, Dushanbe. [in Russian]

SÁnchez-Chico, F., Mamet, B., Moreno-Eiris, E. \& RodrígueZ, S. 1995. Algas calcáreas del Viseense de Los Santos de Maimona (Badajoz). Revista Española de Micropaleontología 27(2), 67-96.

SCHÄFER, P. \& SEnOwBARI-DARYAN, B. 1983. Die Kalkalgen aus der Obertrias von Hydra, Griechenland. Palaeontographica, Abteilung B 185(4-6), 83-142.

SCHAFFNER, J.H. 1909. The classification of plants IV. The Ohio Naturalist 9, 446-455.

SChAFFNER, J.H. 1922. The classification of plants XII. The Ohio Journal of Science 22(5), 129-139. http://hdl.handle.net/1811/2166

SCHAFHÄUTL, K.E. 1863. Süd-Bayerns Lethaea Geognostica. 487 pp. Verlag von Leopold Voss, Leipzig.

SEbBAR, A. 1990. Algues serpoukhoviennes (Carbonifère inférieur) du bassin de Béchar, Algérie. Revue de Micropaléontologie 33(2), 138-143.

Sebbar, A. 1998. Foraminifères et algues calcaires du Carbonifère, bassin de Reggane, Sahara central, Algérie. Bulletin du Service géologique de l'Algérie 9(2), 123-147.

Sebbar, A. 2000. Dynamique des microfossiles (foraminifères benthiques et algues calcaires) en relation avec leurs microfaciès carbonifères dans le Sahara nord-ouest algérien (bassins de Béchar, Reggane et Tindouf). Ph.D. thesis 01/2000, Algiers.

SebBaR, A. \& Lys, M. 1989. Biostratigraphie du Carbonifère inférieur: Serpoukhovien du Djebel Arlal, Bassin de Béchar (Algérie). Revue de Micropaléontologie 32(1), 53-62.

Sebbar, A. \& Mamet, B.L. 1996. Algues benthiques calcaires du Carbonifère inférieur et moyen du bassin de Béchar, Algérie. Revue de Micropaléontologie 39, 153-167. DOI 10.1016/S0035-1598(96)90044-6 
Sebbar, A. \& Mamet, B.L. 1999. Algues benthiques calcaires et Incertae sedis du Carbonifère, bassin de "Béchar-Mézarif", Algérie. Rôle sédimentologique. Revue de Micropaléontologie 42, 71-82. DOI 10.1016/S0035-1598(99)90197-6

Senowbari-Daryan, B. \& Link, M. 2004. Bevocastria magna $\mathrm{n}$. sp., eine neue Cyanobakterie aus den obertriassischen Riffkalken des Taurusgebirges (Türkei). Paläontologische Zeitschrift 78(2), 301-306. DOI 10.1007/BF03009227

Senowbari-Daryan, B. \& Link, M. 2005. Solenoporaceen aus den obertriassischen Riffkalken des Taurusgebirges (Antalya-Gebiet, Südtürkei). Paläontologische Zeitschrift 79(4), 409-427. DOI 10.1007/BF02988370

Senowbari-Daryan, B. \& Rigby, J.K. 2007. Hikorocodium Endo is not an alga but an inozoid sponge. Canadian Journal of Earth Sciences 44, 149-154. DOI 10.1139/e06-070

SHUYSKY, V.P. 1973. Early Devonian reefal calcareous algae from the Urals. Akademiya nauk SSSR, Uralskii nauchnyi tsentr, Institut geologii i geokhimii [in Russian]

SHUYSKY, V.P. 1985. On the position of the Palaeoberesellids and other segmented algae from the group Siphonophyceae, 86-95. In Chuvashov, B.I. (ed.) New data on the geology, biostratigraphy and palaeontology from the Urals. Akademiya nauk SSSR, Uralskii nauchnyi tsentr, Institut geologii i geokhimii. [in Russian]

SHUYSKY, V.P. 1999. Problems of systematics and history of the phylum of the fossil red algae, 248-260. In Chuvashov, B.I. (ed.) Materialy po stratigrafii $i$ paleontologii Urala. Rossiiskaya akademiya nauk, Uralskoe otdelenie 2. [in Russian]

Shvetsov, M.S. \& Birina, L.M. 1935. On the problems of the petrology and origin of the Oka limestones of the Mikhailov-Aleksin area. Trudy Moskovskogo geologicheskogo tresta 10, 1-86. [in Russian]

Silva, P.C. \& Johansen, H.W. 1996. Order Corallinales, 146-152. In WoMersley, H.G.S. (ed.) The marine benthic flora of southern Australia. Part IIIB. Gracilariales, Rhodymeniales, Corallinales and Bonnemaisoniales. Australian Biological Resources Study, Canberra.

SKOMPSKI, S. 1981. Morphology and systematic position of the Carboniferous algal genus Calcifolium. Neues Jahrbuch für Geologie und Paläontologie, Monatshefte 3, 165-179.

Skompski, S. 1984. The functional morphology of the Carboniferous dasycladacean genus Kulikia. Neues Jahrbuch für Geologie und Paläontologie, Monatshefte 7, 427-436.

SкомтsкI, S. 1986. Upper Visean calcareous algae from the Lublin Coal Basin. Acta Geologica Polonica 36(1/3), 251-280.

SkompSKI, S. 1987. The dasycladacean nature of Late Paleozoic palaeoberesellid algae. Acta Geologica Polonica 37(1/2), 21-31.

SKOMPSKI, S. 1996. Stratigraphic position and facies significance of the limestone bands in the subsurface Carboniferous succession of the Lublin Upland. Acta Geologica Polonica 46(3-4), 171-268.

Skompski, S., Conil, R., Laloux, M. \& Lys, M. 1989. Etude micropaléontologique des calcaires du Viséen terminal et du Namurien dans le bassin carbonifère de Lublin à l'Est de la Pologne. Bulletin de la Société belge de Géologie 98(3/4), 453-472.

Sollas, W.J. 1921. On Saccammina carteri Brady, and the minute structure of the foraminiferal shell. Quarterly Journal of the Geological Society of London 77, 193-211.

DOI 10.1144/GSL.JGS.1921.77.01-04.10

SoMERVILLE, I.D. 2008. Biostratigraphic zonation and correlation of Mississippian rocks in Western Europe: some case studies in the late Visean/Serpukhovian. Geological Journal 43, 209-240. DOI 10.1002/gj.1097

Stanier, R.Y. 1974. Division I. The Cyanobacteria. In Buchanan, R.E. \& GibBons, N.E. (ed.) Bergey's manual of determinative bacteriology. The Williams \& Wilkins Co., Baltimore.

STOLLEY, E. 1893. Über silurische Siphonen. Neues Jahrbuch für Mineralogie 2, 135-146.

Termier, H. \& Termier, G. 1950. Paléontologie marocaine. Tome II: Invertébrés de l'ère primaire. Fasc. 1, foraminifères, spongiaires et coelentérés. Notes et Mémoires du Service Géologique de Maroc 73, 1-220.

Termier, H., Termier, G. \& Vachard, D. 1975. Recherches micropaléontologiques dans le Paléozoïque supérieur du Maroc Central. Cahiers de Micropaléontologie 4, 1-99.

Termier, G., Termier, H. \& VAchard, D. 1977. Etude comparative de quelques Ischyrosponges. Géologie Méditerranéenne $4,139-180$.

VACHARD, D. 1974a. Sur les dasycladacées métaspondyles "vestibulaires", à propos d'un de leurs représentants viséens: Eovelebitella occitanica n. gen n. sp. Comptes Rendus de l'Académie des Sciences de Paris 279(25), 1855-1858.

VACHARD, D. 1974b. Contribution à l'étude stratigraphique et micropaléontologique (algues et foraminifères) $d u$ Dévonien-Carbonifère inférieur de la partie orientale du versant méridional de la Montagne Noire (Hérault, France). $\mathrm{PhD}$ thesis, Paris.

VAChARD, D. 1976. Problématique des micro-organismes du Paléozoïque supérieur. $4^{\text {ème }}$ Réunion des Sciences de la Terre, Paris, 385.

VACHARD, D. 1977a. Algues et pseudo-algues du Viséen-Serpoukhovien du Sud de la France (Montagne Noire, Pyrénées). Annales de la Société géologique du Nord 96(4), 373-378.

VACHARD, D. 1977b. Etude stratigraphique et micropaléontologique (algues et foraminifères) du Viséen de la Montagne Noire (Hérault, France). Mémoires de l'Institut géologique de l'Université de Louvain 29, 111-195.

VAChARD, D. 1980. Téthys et Gondwana au Paléozoïque supérieur; les données afghanes: biostratigraphie, micropaléontologie, paléogéographie. Documents et Travaux IGAL, Institut Géologique Albert de Lapparent 2, 1-463.

VACHARD, D. 1988. Calcareous microfossils (algae, pseudo-algae and foraminifera) from La Serre, Montagne Noire, France. Courier Forschungsinstitut Senckenberg 100, 139-147.

VACHARD, D. 1989. Microfossils and microfacies of the Lower Carboniferous limestones, 31-40. In Fontaine, H. \& GAFOER, S. (eds) The Pre-Tertiary fossils of Sumatra and their environments. CCOP Technical Publication 19, Bangkok.

VACHARD, D. 1991. Parathuramminides et moravamminides (Microproblematica) de l'Emsien supérieur de la Formation Moniello (Cordillères Cantabriques, Espagne). Revue de Paléobiologie 10(2), 255-299.

VACHARD, D. 1993. Algues, pseudo-algues et microfaciès carbonatés du Dévonien du domaine Ligérien (Massif Armoricain, France). Palaeontographica, Abteilung B 229(1-3), 53-113. 
VACHARD, D. \& ARETZ, M. 2004. Biostratigraphical precisions on the Early Serpukhovian (Late Mississippian), by means of a carbonate algal microflora (cyanobacteria, algae and pseudoalgae) from La Serre (Montagne Noire, France). Geobios 37(5), 643-666. DOI 10.1016/j.geobios.2003.05.008

Vachard, D., Beauchamp, J. \& Tourani, A. 1991. Le Carbonifère inférieur du Haut-Atlas de Marrakech (Maroc): faciès, microfossiles et traces fossiles. Géologie Méditerranéenne 18(1-2), 3-19.

VACHARD, D. \& BECKARY, S. 1991. Algues et foraminifères bachkiriens des coal balls de la Mine Rosario (Truebano, Léon, Espagne). Revue de Paléobiologie 10(2), 315-357.

VACHARD, D. \& BERKHLI, M. 1992. Importance des coupes du bassin de Jérada (Maroc) pour la connaissance du Viséen terminal. Revue de Micropaléontologie 35(4), 307-328.

VACHARD, D. \& CózAR, P. 2005. Falsocalcifolium nov. gen., and revision of the tribe Calcifolieae (Mississippian, incertae sedis algae). Geobios 38, 803-822. DOI 10.1016/j.geobios.2004.05.004

VACHARD, D. \& CózAR, P. 2010. An attempt of classification of the Palaeozoic incertae sedis Algospongia. Revista Española de Micropaleontología 42, 129-241.

Vachard, D., Cózar, P., Aretz, M. \& Izart, A. in press. Late Viséan-early Serpukhovian foraminifers in the Montagne Noire (France). Geobios.

Vachard, D., Gaillot, J., Vaslet, D. \& Le Nindre, Y.M. 2005. Foraminifers and algae from the Khuff Formation (late Middle Permian-Early Triassic) of central Saudi Arabia. GeoArabia 10(4), 137-186.

Vachard, D., Hauser, M., Martini, R., Zaninetti, L., Matter, A. \& Peters, T. 2001. New algae and problematica of algal affinity from the Permian of the Aseelah Unit of the Batain Plain (East Oman). Geobios 34(4), 375-404.

DOI 10.1016/S0016-6995(01)80003-6

Vachard, D., Krainer, K. \& Lucas, S. 2012. Pennsylvanian (Late Carboniferous) calcareous microfossils from Cedro Peak (New Mexico, USA); Part 1: Algae and Microproblematica. Annales de Paléontologie 98(4), 225-252. DOI 10.1016/j.annpal.2012.06.003

VAChard, D. \& MAslo, A. 1996. Précisions biostratigraphiques et micropaléontologiques sur le Bashkirien d'Ukraine (Carbonifère moyen). Revue de Paléobiologie 15(2), 357-383.

VACHARD, D. \& MontenAT, C. 1981. Biostratigraphie, micropaléontologie et paléogéographie du Permien de la région de Tezak (Montagnes Centrales d'Afghanistan). Palaeontographica, Abteilung B 178(1-3), 1-88.

Vachard, D., Perret, M.F. \& Delvolvé, J.J. 1989. Algues, Pseudo-algues et Foraminifères des niveaux baschkiriens dans les secteurs d'Escarra et Aragon Subordan (Pyrénées aragonaises, Espagne). Geobios 22(6), 697-723.

DOI 10.1016/S0016-6995(89)80068-3

Vachard, D., Pille, L. \& Gaillot, J. 2010. Palaeozoic Foraminifera: systematics, palaeoecology and responses to the global changes. Les foraminifères paléozoïques: systématique, paléoécologie et réponses aux changements globaux.
Revue de Micropaléontologie 53, 209-254.

DOI 10.1016/j.revmic.2010.10.001

VAchard, D., Somerville, I.D. \& Cózar, P. 2004. Fasciella and Praedonezella (Mississippian-early Pennsylvanian algae): Revision and new species. Revista Espańola de Micropaleontología 36(2), 263-278.

VACHARD, D. \& TAHIRI, A. 1991. Foraminifères, algues et pseudo-algues du Viséen de la région d'Oulmès (Maroc). Géologie Méditerranéenne 18(1-2), 21-41.

VACHARD, D., Termier, G. \& Termier, H. 1977. La transgression viséenne au Jebel Goulib (Maroc Central). Bulletin de la Société Linéenne de Lyon 46(8), 267-281.

Vachard, D., Termier, G. \& Termier, H. 1978. Sur l'appartenance systématique des algues Solénoporacées. Comptes Rendus de l'Académie des Sciences de Paris 286, 1865-1868.

VIESLET, J.L. 1983. Description d'une microfaune de foraminifères à la base du Viséen moyen de la région de Tiflet (Maroc). Bulletin de la Société belge de Géologie 92(4), 273-291.

Vologdin, A.G. 1932. Archaeocyathids of Siberia 2: Fauna from the Cambrian limestones of Altai. 106 pp. Gosudarstvennoe nauchno-teknicheskoe geologo-razvedochnoe izdatelstvo, Moscow \& Leningrad. [in Russian]

WetHeRED, E. 1886. On the structure and organisms of the Lower limestone Shales, Carboniferous Limestone and Upper Limestones of the Forest of Dean. Geological Magazine 23, 529-534. DOI 10.1017/S0016756800466884

WOELKERLING, W.J. 1988. The coralline red algae: an analysis of the genera and subfamilies of nongeniculate Corallinaceae. 268 pp. British Museum (National History) and Oxford University Press, London, Oxford \& New York.

Wood, A. 1940. Two new calcareous algae of the family Dasycladaceae from the Carboniferous Limestone. Proceedings Liverpool Geological Society 18(1), 14-18.

Wood, A. 1941. The Lower Carboniferous calcareous algae Mitcheldeania Wethered and Garwoodia gen. nov. Proceedings Geological Association 52, 216-226.

DOI 10.1016/S0016-7878(41)80006-6

WooD, A. 1942. The algal nature of the genus Koninckopora Lee; its occurrence in Canada and Western Europe. Quarterly Journal Geological Society London 98(3-4), 205-222. DOI 10.1144/GSL.JGS.1942.098.01-04.11

Wood, A. 1963. The British Carboniferous species of Girvanella (calcareous algae). Palaeontology 6(2), 264-273.

Wood, A. 1964. A new Dasycladacean alga, Nanopora, from the Lower Carboniferous of England and Kazakhstan. Palaeontology 7(2), 181-185.

WRAY, J.L. 1964. Archaeolithophyllum, an abundant calcareous alga in limestones of the Lansing Group (Pennsylvanian), Southeastern Kansas. State Geological Survey of Kansas 170(1), 3-13.

YABE, H. 1912. Über einige gesteinbildende Kalkalgen von Japan und China. Science Reports of the Tôhoku Imperial University, Sendai, second series (Geology) 1(1), 1-8.

YABE, H. \& Toyama, S. 1928. On some rock-forming algae from the younger Mesozoic of Japan. Science Reports Tohoku University Sendai 12(1), 141-152. 